WCH-208

Rev. 0

River Corridor Closure Contract

\title{
Polychlorinated Biphenyl Presence in the Columbia River Corridor
}

September 2007

Washington Closure Hanford

Prepared for the U.S. Department of Energy, Richland Operations Office Office of Assistant Manager for River Corridor 
TRADEMARK DISCLAIMER

Reference herein to any specific commercial product, process, or service by trade name, trademark, manufacturer, or otherwise, does not necessarily constitute or imply its endorsement, recommendation, or favoring by the United States Government or any agency thereof or its contractors or subcontractors.

This report has been reproduced from the best available copy. Available in paper copy and microfiche.

Available for a processing fee to U.S. Department of Energy and its contractors from:

U.S. Department of Energy

Office of Scientific and Technical Information

P.O. Box 62

Oak Ridge, TN 37831-0062

(865) $576-8401$

fax: (865) 576-5728

email: reports@adonis.osti.gov

online ordering: http://www.doe.gov/bridge

Available for sale to the public, in paper, from:

U.S. Department of Commerce

National Technical Information Service

5285 Port Royal Road

Springfield, VA 22161

(800) 553-6847

fax: (703) 605.6900

email: orders@ntis.fedworld.gov

online ordering: http://www.ntis.gov/ordering.htm

Printed in the United States of America

DISCLM-5.CHP (11/99) 
WCH-208

Rev. 0

\section{STANDARD APPROVAL PAGE}

Title: Polychlorinated Biphenyl Presence in the Columbia River Corridor

Author Name: R. M. Hermann

Approval: $\quad$ E. T. Feist, Manager

Environmental Protection

Mission Completion Project

$\frac{\sum T \text { Jees }}{\text { Signature }} \frac{9 / 5 / 07}{\text { Date }}$

\section{DOCUMENT
CONTROL MJP oq/10/07}

The approval signatures on this page indicate that this document has been authorized for information release to the public through appropriate channe/s. No other forms or signatures are required to document this information release. 

WCH-208

Rev. 0

\title{
River Corridor Closure Contract
}

\section{Polychlorinated Biphenyl Presence in the Columbia River Corridor}

September 2007

\author{
Author: \\ R. M. Hermann
}





\section{EXECUTIVE SUMMARY}

The purpose of this paper is to summarize the potential for polychlorinated biphenyl (PCB) contamination of Hanford Site origin for the River Corridor Baseline Risk Assessment (RCBRA) (DOE/RL-2007-21). PCBs were functionally attractive materials used in transformers, hydraulic equipment, capacitors, paint, sealants, and light ballasts. PCB exposure was found to result in harmful effects leading Congress and the U.S. Environmental Protection Agency (EPA) through the Toxic Substances Control Act (40 Code of Federal Regulations 761) to halt manufacturing, prohibit use, and regulate disposal beginning in1976.

PCBs are a group of 209 compounds, referred to as congeners, that were commercially produced and distributed predominantly in specific mixtures of congeners, referred to as Aroclors. PCB congeners with higher levels of chlorination are more persistent in the environment, bioaccumulating in environmental media with little degradation over time. Aroclor mixtures found in various forms of media at the Hanford Site include Aroclor-1248, Aroclor-1254, and Aroclor-1260. These mixtures are composed predominantly of less degradable congeners. Chemical properties of the PCBs used on site indicate the relatively low potential for mobility through the environment, causing these releases to remain relatively confined to the point of release.

Pathways for contamination include potential releases from past disposal, leaks, or spills, and in contaminated sediment from off-site upstream sources. PCB waste oils were mixed with nonPCB oils and disposed of on roadways during a period of unregulated disposal. A limited number of roads were identified as likely to have had PCB-containing waste oil applied and therefore should be investigated

Although PCBs have been identified in Columbia River tributaries upstream of the Hanford Site, contaminated sediments from those sources are impeded by a series of dams. The Hanford Reach section of the Columbia River is characterized by a swift current, cobble bottom and shores, and a small number of depositional areas that could harbor PCB-contaminated sediment. These characteristics, along with the roaming nature of the fish species from the Hanford Reach found to contain PCBs, make association with a local Hanford Site source unlikely. 
Soil, water, and sediment samples used to characterize Hanford Site PCB contamination were historically analyzed and reported with detection levels that met cleanup criteria for PCBs.

However, fish tissue analyzed during this risk assessment was reported with levels of detection one to two orders of magnitude above EPA screening criteria for human health. The effect of these data is a need for evaluation of methodologies for the analysis of PCBs and a reanalysis of fish tissue.

There are a number of Hanford Site waste sites with PCB-contaminated soil. However, migration pathways do not indicate transportation of that contamination to exposure mediums such as groundwater and Columbia River surface water. 


\section{TABLE OF CONTENTS}

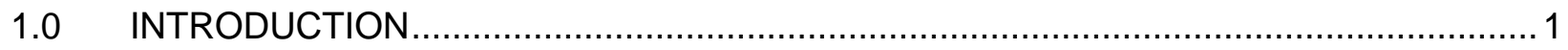

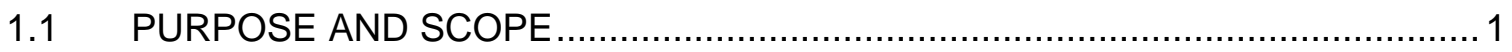

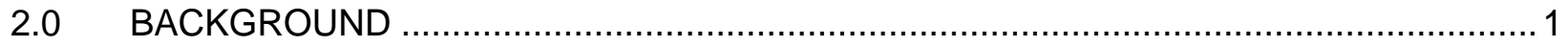

2.1 PERSISTENCE AND CHEMICAL DEGRADATION.................................... 3

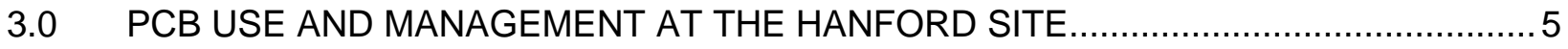

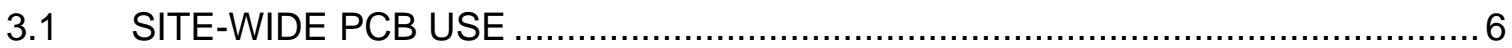

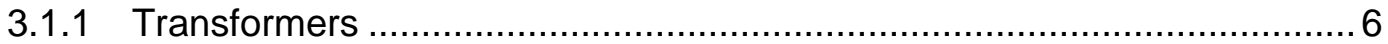

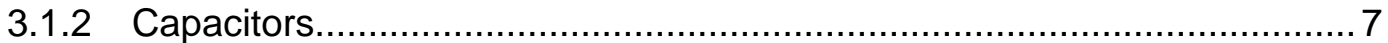

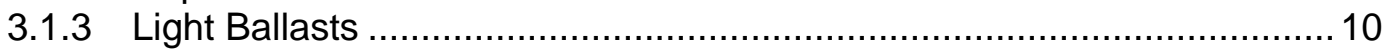

3.1.4 Paints and Sealants................................................................. 10

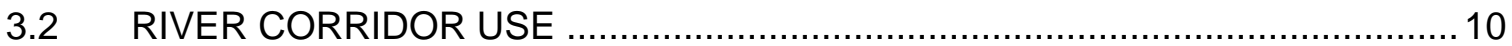

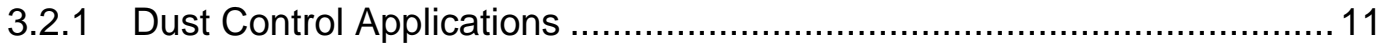

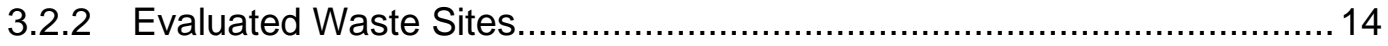

3.2.3 100 Area Fuel Storage Basins ........................................................ 17

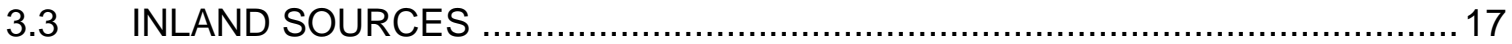

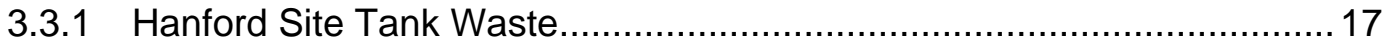

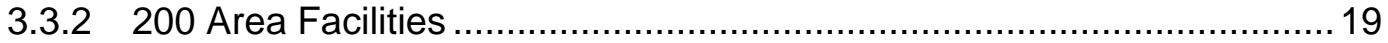

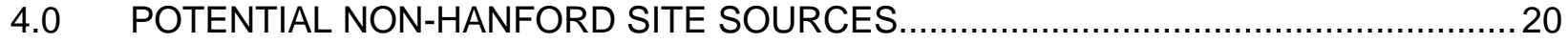

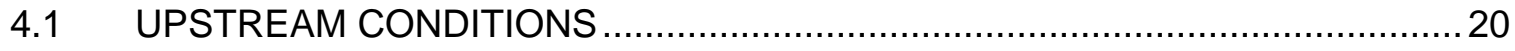

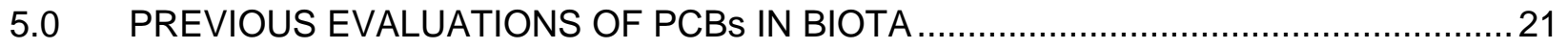

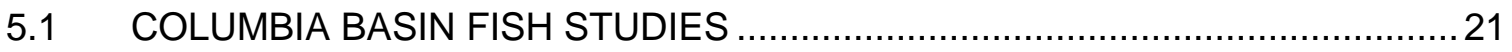

5.2 RIVER CORRIDOR SCULPIN AND SUCKER STUDIES ...............................24

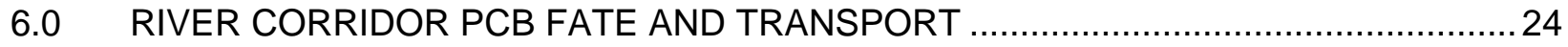

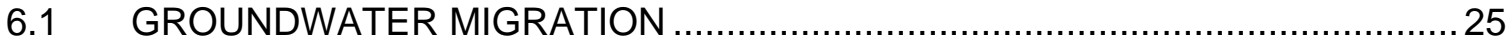

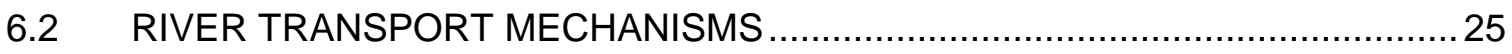

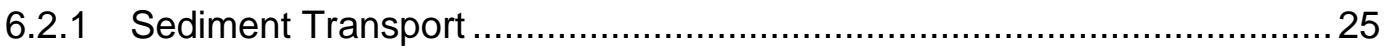

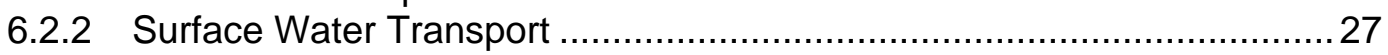

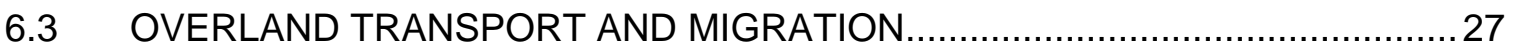

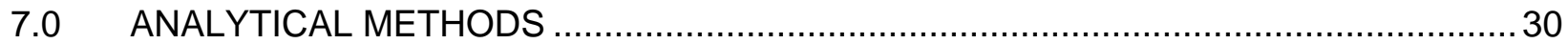


9.0 REFERENCES.

\section{APPENDICES}

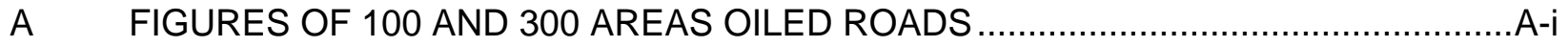

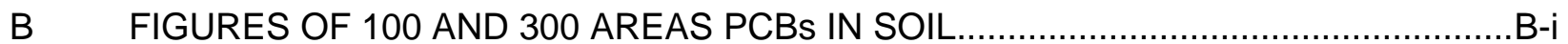

C DATA TABLES FOR 100 AND 300 AREAS PCBS IN SOIL ................................... C-i

D EVALUATION OF PCB CONCENTRATIONS ESTIMATED IN 2004 SCULPIN........... D-i

E PCB CONGENERS MOST ABUNDANT IN AROCLORS 1248, 1254, AND 1260 .........E-i

\section{FIGURES}

1. Percentage of Isomer Homolog in Aroclor Mixtures............................................. 4

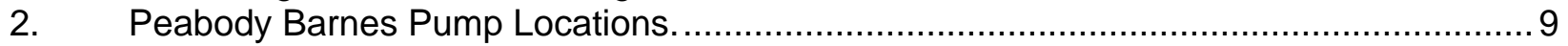

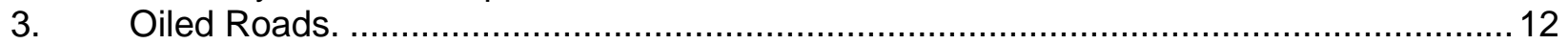

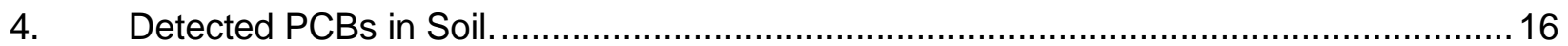

5. Conceptual Site Model for PCB Migration and Exposure ....................................... 29

\section{TABLES}

1. $\quad$ PCB Aroclor Uses in Commercial Products. ........................................................ 2

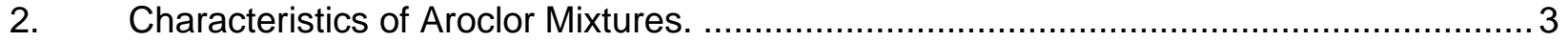

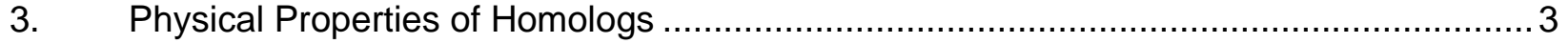

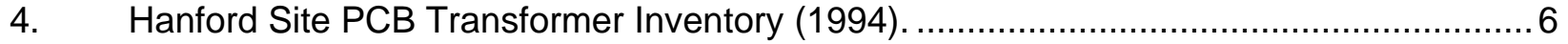

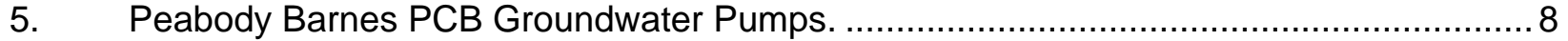

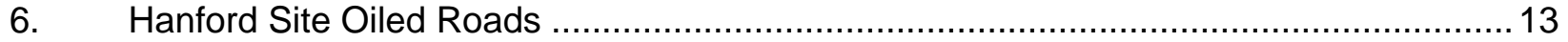

7. Investigation Summary of Electrical-Related PCB Sites. ...................................... 14

8. Hanford Site Waste Tank PCB Summary. ......................................................... 18

9. PCB Concentrations in Water, Sediment, and Fish. .............................................. 20

10. Columbia River Basin PCB Concentrations (ppb) in Mountain Whitefish and

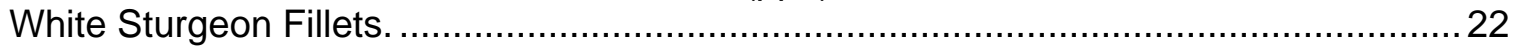

11. National, Statewide, Spokane River, and Columbia River Total PCB Levels in

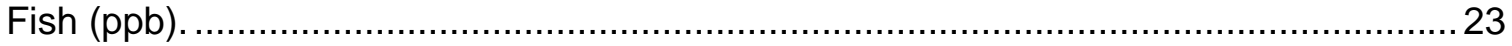

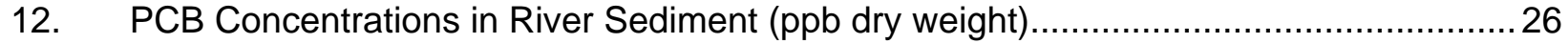

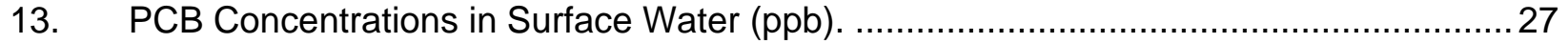

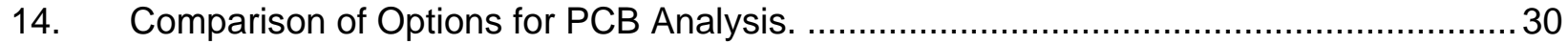

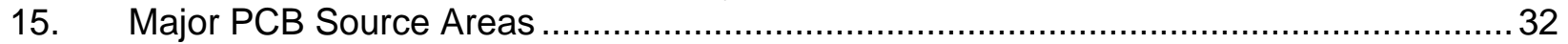




\section{ACRONYMS}

$\begin{array}{ll}\text { CFR } & \text { Code of Federal Regulations } \\ \text { COPC } & \text { contaminant of potential concern } \\ \text { EPA } & \text { U.S. Environmental Protection Agency } \\ \text { ERDF } & \text { Environmental Restoration Disposal Facility } \\ \text { DOE } & \text { U.S. Department of Energy } \\ \text { HEIS } & \text { Hanford Environmental Information System } \\ \text { PCBS } & \text { polychlorinated biphenyl } \\ \text { RCBRA } & \text { River Corridor Baseline Risk Assessment } \\ \text { SESP } & \text { Surface Environmental Surveillance Project } \\ \text { TSCA } & \text { Toxic Substances Control Act } \\ \text { WIDS } & \text { Waste Information Data System }\end{array}$




\section{REVISION HISTORY}

\begin{tabular}{|c|c|l|c|}
\hline Revision & Date & \multicolumn{1}{|c|}{ Reason for revision } & Revision initiator \\
\hline 0 & $09 / 2007$ & Initial issuance & NA \\
\hline
\end{tabular}


WCH-208

Rev. 0 


\subsection{INTRODUCTION}

The U.S. Department of Energy (DOE) is required by Comprehensive Environmental Response, Compensation, and Liability Act of 1980 regulations to develop a conceptual understanding of potential contaminant releases from the Hanford Site based on an evaluation of existing data and known historical practices. Polychlorinated biphenyls (PCBs) are one environmental contaminant potentially released through leaks, spills, or disposal. This contaminant is known to be persistent in the environment and of popular use prior to 1976. The DOE has decided to complete this summary as part of the River Corridor Baseline Risk Assessment (RCBRA) and in response to comments received while preparing the draft Risk Assessment Report for the 100 Area and 300 Area Component of the RCBRA (DOE/RL-2007-21). This document presents a summary of selected relevant existing information, including environmental studies and Hanford Site analytical data.

\subsection{PURPOSE AND SCOPE}

Since becoming regulated as a toxic substance in the late 1970s, the presence, disposal, and tracking of PCBs at the Hanford Site has been recorded but never compiled. The purpose of this paper is to identify the potential for PCB contamination throughout the 100 and 300 Areas and the Inter-Areas as defined in the River Corridor Baseline Risk Assessment. Contributions will be addressed from Hanford Site sources, both from the river corridor operable units, Central Plateau, and non-Hanford Site upstream sources. To address this range of variables, a collection of previous evaluations will be incorporated into this summary. To address the likelihood, presence, or absence of contamination, there will be an overview of environmental fate and transport pertinent to the Hanford Site.

\subsection{BACKGROUND}

PCBs are synthetic organic compounds unique for their heat-resistant, lubrication, insulating, and cooling properties. When present, they are found most commonly in hydraulic fluids, lubricants, electrical transformers and capacitors, weatherproofing, plasticizers, and caulking. Table 1 provides a more detailed list taken from U.S. Department of Health and Human Services Toxicological Profile for Polychlorinated Biphenyls (PCBS) 2000 (USDHHS 2000). PCB production and distribution in the United States occurred between 1929 and 1977. Evidence of harmful effects from exposure to the compounds led the Congress and the U.S. Environmental Protection Agency (EPA) through the Toxic Substances Control Act (TSCA) (40 Code of Federal Regulations [CFR] 761) to halt manufacturing, prohibit use, and regulate disposal beginning in1976. 
Table 1. PCB Aroclor Uses in Commercial Products.

\begin{tabular}{|l|c|c|c|c|c|c|c|c|c|}
\hline \multirow{2}{*}{ Product } & \multicolumn{9}{c|}{ Aroclor } \\
\cline { 2 - 10 } & $\mathbf{1 0 1 6}$ & $\mathbf{1 2 2 1}$ & $\mathbf{1 2 3 2}$ & $\mathbf{1 2 4 2}$ & $\mathbf{1 2 4 8}$ & $\mathbf{1 2 5 4}$ & $\mathbf{1 2 6 0}$ & $\mathbf{1 2 6 2}$ & $\mathbf{1 2 6 8}$ \\
\hline Capacitors & $\mathrm{x}$ & $\mathrm{x}$ & & & & $\mathrm{x}$ & & & \\
\hline Transformers & & & & $\mathrm{x}$ & & $\mathrm{x}$ & $\mathrm{x}$ & & \\
\hline Heat transfer & & & & $\mathrm{x}$ & & & & & \\
\hline Hydraulic fluids & & & $\mathrm{x}$ & $\mathrm{x}$ & $\mathrm{x}$ & $\mathrm{x}$ & $\mathrm{x}$ & & \\
\hline Vacuum pumps & & & & & $\mathrm{x}$ & $\mathrm{x}$ & & & \\
\hline Gas-transmission turbines & & $\mathrm{x}$ & & $\mathrm{x}$ & & & & & \\
\hline Rubbers & & $\mathrm{x}$ & $\mathrm{x}$ & $\mathrm{x}$ & $\mathrm{x}$ & $\mathrm{x}$ & & & $\mathrm{x}$ \\
\hline Synthetic resins & & & & & $\mathrm{x}$ & $\mathrm{x}$ & $\mathrm{x}$ & & $\mathrm{x}$ \\
\hline Carbonless paper & & & & $\mathrm{x}$ & & & & & \\
\hline Adhesives & & $\mathrm{x}$ & $\mathrm{x}$ & $\mathrm{x}$ & $\mathrm{x}$ & $\mathrm{x}$ & & & \\
\hline Wax extenders & & & & $\mathrm{x}$ & & $\mathrm{x}$ & & & $\mathrm{x}$ \\
\hline Dedusting agents & & & & & & $\mathrm{x}$ & $\mathrm{x}$ & & \\
\hline Inks & & & & & & $\mathrm{x}$ & & & \\
\hline Cutting oils & & & & & & $\mathrm{x}$ & & & \\
\hline Pesticide extenders & & & & & & $\mathrm{x}$ & & & \\
\hline Sealants/caulking & & & & & & $\mathrm{x}$ & & & \\
\hline
\end{tabular}

PCBs are referred to and analyzed for under two primary groupings: congeners and Aroclors. Chemically, PCBs are characterized by varying levels of chlorination of the biphenyl component. The term congener refers to a chemically unique biphenyl with a specific chlorination level and arrangement, ranging from 1 to 10 or mono to decachlorobiphenyl. These 10 levels of chlorination are referred to as homologs, "subcategories of PCB congeners having equal numbers of chlorine substituents" (http://www.epa.gov/toxteam/pcbid/defs.htm\#homolog). Based on isomer positioning and chlorination there are 209 congeners of PCBs. Certain mixtures of congeners form the commercial products known by their common U.S. tradenames as Aroclors. $98 \%$ of PCBs sold in the United States are made up of nine Aroclors distinguishable by a unique four-digit number, where the last two numbers signify the approximate percentage of chlorine found in the mixture. For example, Aroclor-1254 contains $54 \%$ chlorine. The term congener signifies a specific unique compound, and the term Aroclor identifies a mixture of many chemically similar compounds. The difference in laboratory analysis of these two groups of constituents is very specific and resolute in the case of congeners and broad relationally based in the case of Aroclors. However, both analytical methods present problems in terms of analysis and data interpretation.

Physically, the primary nine Aroclors used in the United States can be categorized as oily liquids, viscous liquids or, in the case of Aroclor-1260, a sticky resin. Although industrial use of Aroclors typically takes place in closed systems or exposed but bound forms (caulking), due to a number of reasons PCBs have been released into the environment. 


\subsection{PERSISTENCE AND CHEMICAL DEGRADATION}

PCB mixtures with lower levels of chlorination (e.g., Aroclor-1221 as opposed to Aroclor-1260) are generally more soluble in water, more volatile, and more susceptible to biodegradation. These properties make the less-chlorinated PCBs less persistent in the environment. Conversely, PCB mixtures with higher levels of chlorination tend to be more persistent in the environment, bioaccumulating and remaining in environmental media (mainly soil) with little degradation over time. Tables 2 and 3 show properties of PCBs and Aroclors and help illustrate the factors that come together to cause differences in persistency between the compounds and the mixtures.

Table 2. Characteristics of Aroclor Mixtures.

\begin{tabular}{|c|c|c|c|c|}
\hline Aroclor & Density & Viscosity & $\begin{array}{c}\text { Vaporization rate } \\
\left(\mathbf{g} / \mathbf{c m}^{\mathbf{2}} \mathbf{/ h r} \mathbf{\times} \mathbf{1 0}^{\mathbf{6}} \mathbf{)}\right.\end{array}$ & $\begin{array}{c}\text { Solubility } \\
(\boldsymbol{\mu g} / \mathbf{L})\end{array}$ \\
\hline 1221 & 1.18 & $30-31$ & 1740 & $15,000^{\mathrm{a}}$ \\
\hline 1232 & 1.26 & $31-32$ & 874 & $1,450^{\mathrm{a}}$ \\
\hline 1016 & 1.37 & & & 420 \\
\hline 1242 & 1.38 & $34-35$ & 338 & 240 \\
\hline 1248 & 1.44 & $36-36$ & 152 & 52 \\
\hline 1254 & 1.54 & $44-58$ & 53 & 12 \\
\hline 1260 & 1.62 & $72-78$ & 13 & 3 \\
\hline 1262 & 1.64 & $86-100$ & 9 & \\
\hline 1268 & 1.81 & & & \\
\hline
\end{tabular}

${ }^{a}$ Estimated.

b None to boiling.

Source: Shiu, W. Y. and D. J. Mackay, 1986, J., Phys. Chem. Ref Data, 15(2):911-929.

Table 3. Physical Properties of Homologs. (2 Pages)

\begin{tabular}{|c|c|c|c|}
\hline $\begin{array}{l}\text { PCB Isomer } \\
\text { Group }\end{array}$ & $\begin{array}{c}\text { Vapor } \\
\text { Pressure } \\
(\mathrm{mmHg})\end{array}$ & $\begin{array}{c}\text { Water } \\
\text { Solubility } \\
\left(\mathrm{g} / \mathrm{m}^{3}\right)\end{array}$ & $\begin{array}{c}\text { Approximate } \\
\text { Evaporation Rate @ } \\
25^{\circ} \mathrm{C}\left(\mathrm{g} / \mathrm{m}^{2} / \mathrm{h}\right)\end{array}$ \\
\hline Biphenyl & 4.9 & 9.3 & 0.92 \\
\hline MonoCB & 1.1 & 4.0 & 0.25 \\
\hline DiCB & 0.24 & 1.6 & 0.065 \\
\hline TriCB & 0.054 & 0.65 & 0.017 \\
\hline TetraCB & 0.012 & 0.26 & $4.2 \times 10^{-3}$ \\
\hline PentaCB & $2.6 \times 10^{-3}$ & 0.099 & $1.0 \times 10^{-3}$ \\
\hline HexaCB & $5.8 \times 10^{-4}$ & 0.038 & $2.5 \times 10^{-4}$ \\
\hline HeptaCB & $1.3 \times 10^{-4}$ & 0.014 & $6.2 \times 10^{-5}$ \\
\hline OctaCB & $2.8 \times 10^{-5}$ & $5.5 \times 10^{-3}$ & $1.5 \times 10^{-5}$ \\
\hline NonaCB & $6.3 \times 10^{-5}$ & $2.0 \times 10^{-3}$ & $3.5 \times 10^{-6}$ \\
\hline
\end{tabular}


Table 3. Physical Properties of Homologs. (2 Pages)

\begin{tabular}{|l|c|c|c|}
\hline $\begin{array}{c}\text { PCB Isomer } \\
\text { Group }\end{array}$ & $\begin{array}{c}\text { Vapor } \\
\text { Pressure } \\
(\mathbf{m m H g})\end{array}$ & $\begin{array}{c}\text { Water } \\
\text { Solubility } \\
\left(\mathbf{g} / \mathbf{m}^{3}\right)\end{array}$ & $\begin{array}{c}\text { Approximate } \\
\text { Evaporation Rate } @ \\
\mathbf{2 5}^{\circ} \mathbf{C}\left(\mathbf{g} / \mathbf{m}^{\mathbf{2}} / \mathbf{h}\right)\end{array}$ \\
\hline DecaCB & $1.4 \times 10^{-6}$ & $7.6 \times 10^{-4}$ & $8.5 \times 10^{-7}$ \\
\hline
\end{tabular}

NOTE: Many values are approximations of the range across the isomers.

Source: Shiu, W. Y. and D. J. Mackay, 1986, J., Phys. Chem. Ref Data,15(2):911929.

The level of chlorination (21\% in Aroclor-1221 and 60\% in Aroclor-1260) is directly related to the prevalence of each isomer group, or homolog, in the mixture. Aroclor-1221 is less chlorinated than Aroclor-1260 and therefore has more congeners with mono, di, and tri homologs than Aroclor-1260, which contains more compounds in the penta, hexa, and hepta homologs. Figure 1 illustrates this point more clearly.

Figure 1. Percentage of Isomer Homolog in Aroclor Mixtures.

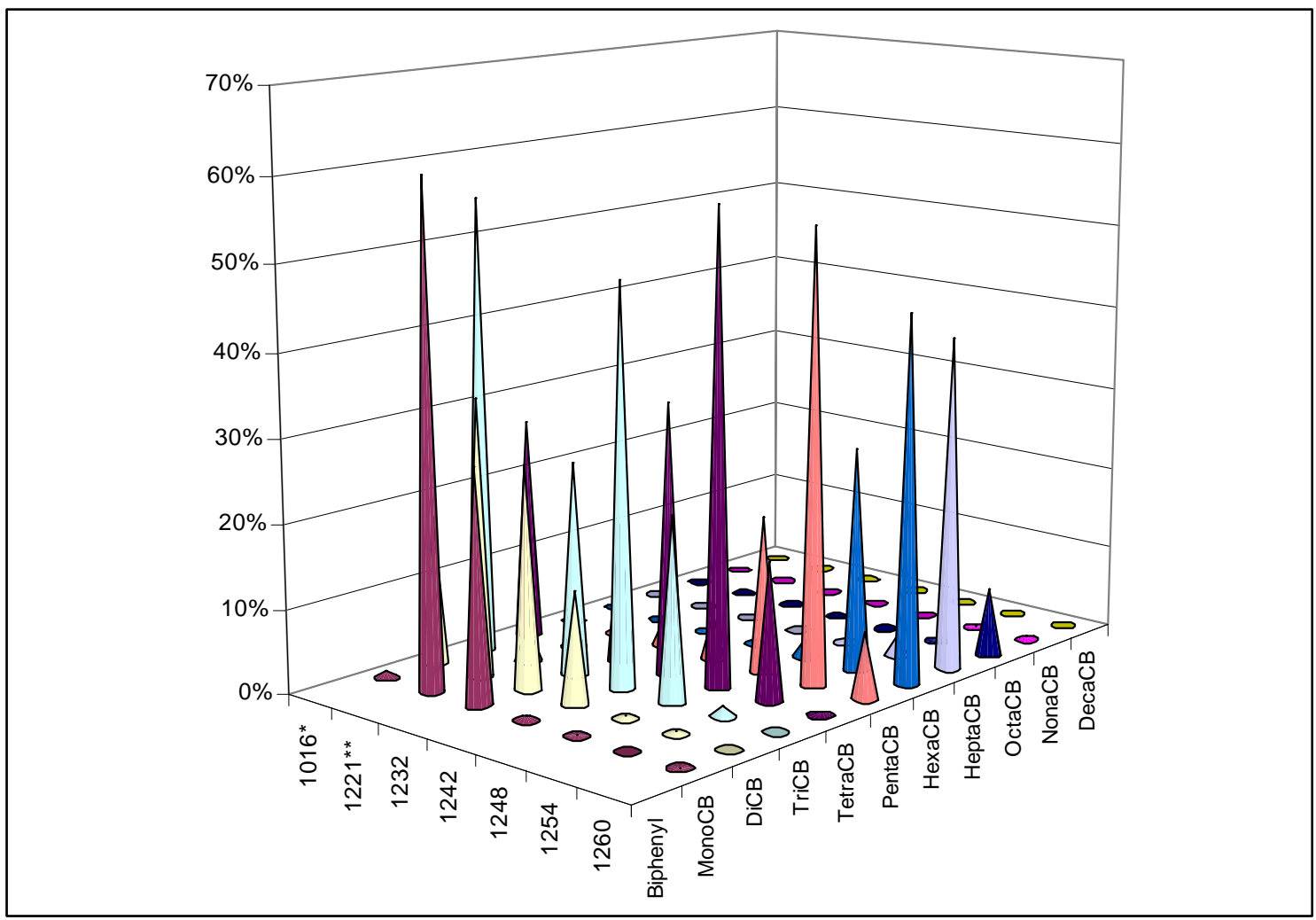

Source: Frame, J., 1996, Journal of High Resolution Chromatography, Vol.19 Dec. 1996, p. 657-668, Interpretation by Mark Marcus $\mathrm{CH} 2 \mathrm{MHill}$ 5-22-2007. 
PCBs have both volatile and sorbent properties and, as a result, are subject to natural transportation globally through air, water, sediment, and soil via the natural forces affecting each medium. Once in the environment, microbial degradation of PCBs through aerobic and anaerobic processes depend on the degree of chlorination and environmental media; air, water, sediment, or soil. In general, as the level of chlorination increases, the more chlorine atoms are in the congener, and the more difficult the compound is to biodegrade.

Eisler (1986) illustrated that partition coefficients and steric factors influence bioavailability and uptake of PCBs from aqueous media. Particularly important for PCBs is the octanol-water partition coefficient $\left(\mathrm{K}_{\mathrm{ow}}\right)$, which indicates the tendency of a compound to partition between octanol (representative of natural organic matter) and water. The higher the $\mathrm{K}_{\mathrm{ow}}$, the more likely a compound is to sequester into organic material, either in soil or sediment, or in body fat. High partition coefficients, as observed in various PCB homologs, lead to high biological uptake potential. Therefore, the tendency is for PCBs to adhere to organic matter found in environmental media such as soil, sediment, and tissue, and the amount of organic matter available for binding is critical in assessing the likelihood of PCB retention.

As mentioned previously and shown in Figure 1 and Tables 2 and 3, PCBs are mixtures of compounds that adhere to solid materials, have low solubility in water, and do not easily volatilize. Therefore, movement of the Aroclors and similarly chlorinated PCB mixtures that could be found on the site is limited. Release to and transport through groundwater is unlikely since the mixtures identified on site are generally hydrophobic and would more readily adhere to soil particles. For the same reasons, volatilization and transportation through the atmosphere of PCBs in the mixtures found on site is equally unlikely. Overland movement of contaminated soils via runoff, wind dispersion, or adherence to vehicle tires on oiled roadways are more likely transport mechanisms. In the aquatic environment, fluvial transport and redistribution of historically contaminated sediments would be the primary transport mechanisms. These migration pathways are illustrated in a conceptual site model shown in Figure 5.

\subsection{PCB USE AND MANAGEMENT AT THE HANFORD SITE}

Materials and equipment known to contain PCBs have been used across the Hanford Site, as the chemicals were widely used worldwide. For the most part, sources along the river corridor and inland sources were similar in nature. Sites and equipment such as electrical substations, transformers, capacitors, roofing material, and caulking can be found at various locations across the Hanford Site indiscriminant of operable unit. Historical onsite disposal areas, such as burial and dumping grounds, are a feature of past Hanford Site operations. These sites, among others, are addressed in the following sections. A conceptual site model presented in Section 6.0 shows pathways to the environment for sources of Hanford Site PCB contamination described in this section. 


\subsection{SITE-WIDE PCB USE}

\subsubsection{Transformers}

Electrical transformers at the Hanford Site are a known source of fluids containing PCBs. Built into the infrastructure of the 100 and 300 Areas are electrical substations and electrical transformers. Management of PCBs and guidelines for handling, remediating, transporting, storing, and disposing of PCB materials and equipment are found in the Toxic Substances Control Act Polychlorinated Biphenyls Hanford Site Users Guide (DOE/RL-2001-50). This document provides uniform guidance at the Hanford Site on TSCA interpretation, specifically 40 CFR 761.

A PCB transformer inventory summarized in Table 4, representing transformers with PCB oil in excess of 50 ppm, was compiled as a result of deficiencies found during Environmental Compliance Review No. ECR-94-04 (Deatherage 1995).

Table 4. Hanford Site PCB Transformer Inventory (1994).

\begin{tabular}{|c|c|c|c|}
\hline $\mathbf{1 0 0}$ Area & $\mathbf{2 0 0}$ Area & $\mathbf{3 0 0}$ Area & $\mathbf{4 0 0}$ and 600 Areas \\
\hline 190 & 870 & 300 & 160 \\
\hline
\end{tabular}

The basis for assessment was PCB management practices (40 CFR 761). The three deficiencies found involved leak discovery, maintaining spill cleanup records, and certificates of disposal. Corrective actions included labeling all transformers with PCB levels and inspecting regularly, obtaining a copy of cleanup documentation from the electrical utility, and obtaining copies of all certificates of disposal from the responsible engineering organization.

Annually Fluor Hanford (and previously Westinghouse Hanford Company) prepares an annual log and report detailing PCB handling activities. Documented in the 2005 Annual Polychlorinated Biphenyl Annual Document Log (DOE/RL-2006-42) are records of removal of PCB-containing equipment and contaminated material or debris dating back to 1982 . Spatially the items and materials removed came from sources throughout the site. As of December 31, 2005 , ten nonradioactive PCB-containing transformers and one radioactive PCB transformer remained on site. Those remaining nonradioactive transformers reside in the 400 Area, and the remaining radioactive transformer is located in the 200 Area.

One example of PCBs leaking from transformers to soil is found at the $151-\mathrm{H}$ substation, waste site number $100-\mathrm{H}-24$. Cleanup of this waste site is documented in the Waste Information Data System (WIDS) and is typical of other leaking transformer waste sites. Stained soil near transformers signified locations of leaking transformer oil. Areas of stained soil were selected for post excavation sampling to determine the effectiveness of cleanup strategies and sample design. The majority of this site was excavated to a depth of $1 \mathrm{~m}$ below grade level, where cleanup verification samples revealed either undetectable PCB concentrations or concentrations low enough to allow future land use. Results of sampling at one location showed PCBs at levels requiring further excavation beyond $1 \mathrm{~m}$. At this spot the final depth of excavation was $4 \mathrm{~m}$, 
where final cleanup verification samples were collected and showed successful removal of PCB contaminated soil (CVP-2000-00030, 2001).

From verification sampling it was concluded that PCB contamination from transformers would not travel vertically down to groundwater nor horizontally to the river. Contamination down to $4 \mathrm{~m}$ in the 100 Areas where the depth to groundwater ranges from 9 to $18 \mathrm{~m}$ would not have impacted groundwater. Sample results show that horizontally movement is very limited.

The goal of PCB management at the Hanford Site is to remove and dispose of PCBs from the site, and efforts are actively pursuing that goal. PCBs were widely used in transformers and have accounted for small releases. Releases remained isolated to the surface and shallow soils with no threat of extending to a depth impacting groundwater. A program for transformer inspection became a mechanism for leak detection and initiation of cleanup activities. Hanford Site transformer pads and substations have been investigated, and all sites with PCB contamination except for two that are pending remediation have been excavated and backfilled with clean fill material.

\subsubsection{Capacitors}

Detailed removal efforts of PCB-containing capacitors have been and will continue to be captured in the annual PCB reports prepared by Fluor Hanford. As stated before, capacitors are found in equipment used to store electricity. Motors are common devices that use capacitors, and capacitors in motors are sealed devices that would require cracking and leaking to initiate release to the environment.

Some groundwater pumps used in Hanford Site monitoring wells have been found to house capacitors containing PCBs. Once this was realized, the wells that had identified pumps were moved to the top of the list for decommissioning. Submersible in operation, the Peabody Barnes model pumps manufactured prior to 1980 were identified for removal and testing of motor oil for PCB and total organic halides. Rather than performing individual tests, all capacitors within the Peabody Barnes motors were assumed to contain PCBs and disposed of as PCB-containing material.

Because of their direct contact with groundwater, pumps with leaking capacitors would be sources for release of PCBs to the environment. Efforts to break this pathway have resulted in removal and disposal of 8 of 25 Peabody Barnes pumps. Twelve of the total 25 pumps lie within the 100 and 300 Areas, of which 7 have been removed. Table 5 lists the groundwater wells where Peabody Barnes pumps were or are located, along with PCB analytical results from groundwater samples from those wells. To date no PCBs have been detected in groundwater from wells utilizing Peabody Barnes pumps. Figure 2 shows the locations of PCB-containing groundwater pumps. 
Table 5. Peabody Barnes PCB Groundwater Pumps.

\begin{tabular}{|c|c|c|c|c|}
\hline Well ID & Well Number & Qualifier & Concentration (ppb) & Removed \\
\hline A4590 & 199-F5-4 & $U$ & 1 & Yes \\
\hline A4654 & $199-K-28$ & \multicolumn{2}{|c|}{ Not Analyzed for PCBs } & No \\
\hline A4676 & $199-N-27$ & $U$ & 1 & No \\
\hline A4681 & $199-N-32$ & $U$ & 1 & Yes \\
\hline A4693 & $199-N-50$ & $U$ & 1 & Yes \\
\hline A5043 & $399-2-1$ & $U$ & 1 & Yes \\
\hline A5046 & 399-3-1 & \multicolumn{2}{|c|}{ Not Analyzed for PCBs } & Yes \\
\hline A5065 & 699-10-E12 & \multicolumn{2}{|c|}{ Not Analyzed for PCBs } & No \\
\hline A5213 & $699-48-7 A$ & $U$ & 1 & Yes \\
\hline A5221 & $699-49-79$ & $U$ & 1 & Yes \\
\hline A5229 & $699-50-85$ & $U$ & 1 & No \\
\hline A5232 & 699-51-75 & $U$ & 1 & No \\
\hline A5292 & $699-63-58$ & \multicolumn{2}{|c|}{ Not Analyzed for PCBs } & No \\
\hline A5302 & $699-65-72$ & $U$ & 1 & No \\
\hline A5330 & $699-77-36$ & \multicolumn{2}{|c|}{ Not Analyzed for PCBs } & No \\
\hline A5371 & 699-S27-E14 & $U$ & 1 & No \\
\hline A5386 & 699-S32-E13B & \multicolumn{2}{|c|}{ Not Analyzed for PCBs } & No \\
\hline \multicolumn{5}{|c|}{ Inland of 100 and 300 Areas } \\
\hline A8252 & 699-12-4D & \multicolumn{2}{|c|}{ Not Analyzed for PCBs } & No \\
\hline A8445 & $699-22-70$ & \multicolumn{2}{|c|}{ Not Analyzed for PCBs } & No \\
\hline A8457 & $699-24-46$ & \multicolumn{2}{|c|}{ Not Analyzed for PCBs } & Yes \\
\hline A5108 & $699-26-89$ & $U$ & 1 & No \\
\hline A5123 & 699-31-31 & \multicolumn{2}{|c|}{ Not Analyzed for PCBs } & No \\
\hline A8863 & $699-54-49$ & $U$ & 1 & No \\
\hline A8944 & $699-62-43 F$ & \multicolumn{2}{|c|}{ Not Analyzed for PCBs } & No \\
\hline A5365 & 699-S12-29 & \multicolumn{2}{|c|}{ Not Analyzed for PCBs } & No \\
\hline
\end{tabular}


Figure 2. Peabody Barnes Pump Locations.

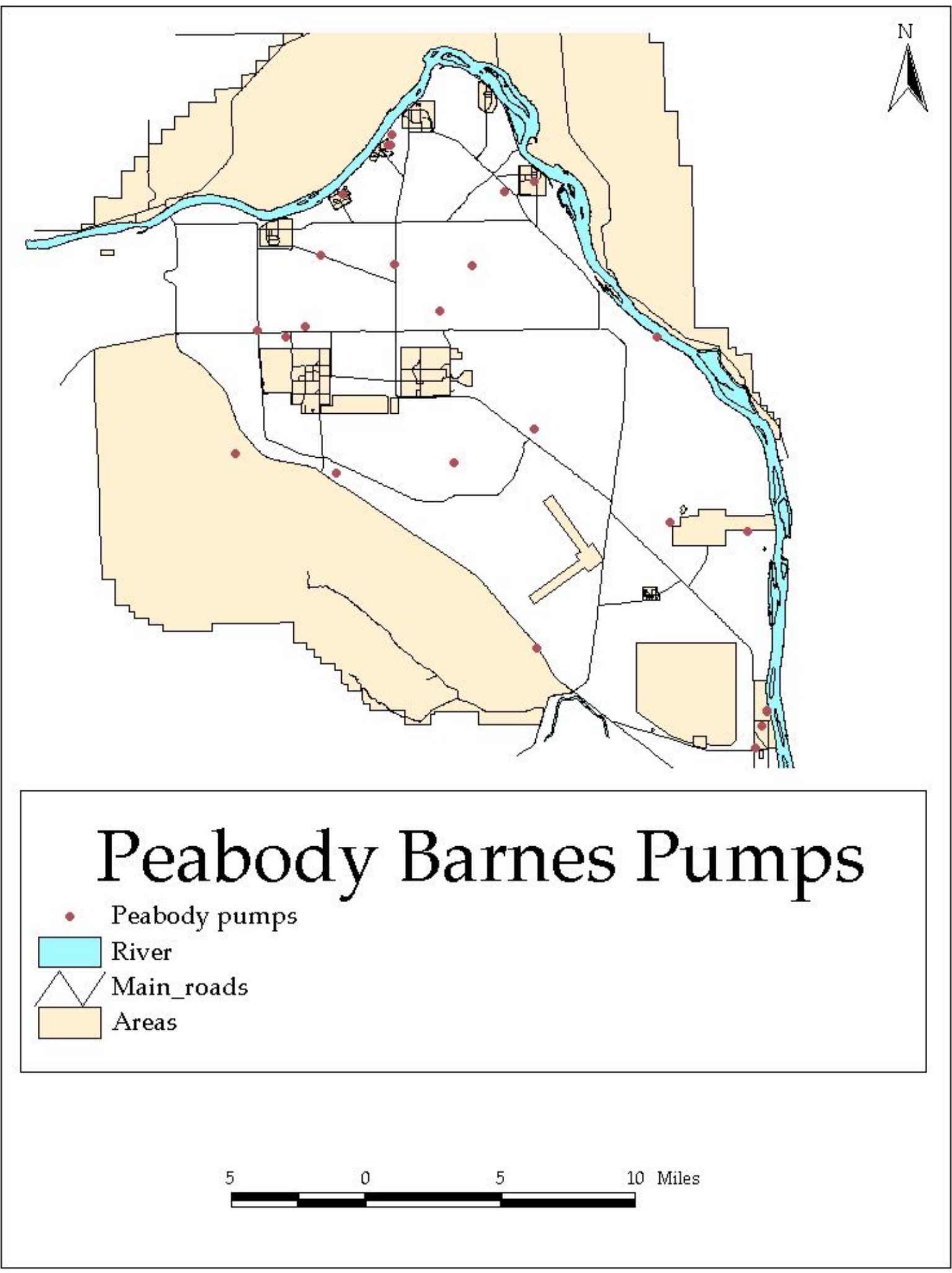




\subsubsection{Light Ballasts}

Fluorescent light ballasts produced prior to 1977 commonly contain PCBs within a small capacitor. The total amount of oil containing PCBs found in fluorescent light ballasts is 28 to $42.5 \mathrm{~g} \mathrm{(1} \mathrm{to} 1.5 \mathrm{oz}$ ). Although light ballasts are a source of PCBs, the likelihood for release to the environment is low because the material resides in a sealed capacitor, inside the ballast, and inside a building. Ballasts documented as leaking or cracked led to spill reports, were cleaned up, and the materials disposed of under TSCA as PCB material. These ballasts are being systematically removed from the site and currently constitute the majority of items in PCB waste shipments, as stated by a Washington Closure Hanford waste transportation and packaging subject matter expert. PCBs in light ballasts are not a source for release to the environment at the Hanford Site, as leaks would be small in volume and concealed within buildings.

\subsubsection{Paints and Sealants}

Paints and sealants containing PCBs were used at the Hanford Site in applications requiring heat-resistant and insulating properties. Building surfaces and process equipment located inside the reactor buildings were commonly coated with paint containing PCBs. During the Environmental Restoration Contractor Reactor Interim Safe Storage Project, paint samples from the reactor facilities were collected, analyzed, and found to contain PCBs in excess of $50 \mathrm{ppm}$. These findings led to the issuance of Management of Demolition Waste Coated with Paints Containing Polychlorinated Biphenyls (PCBS), Reactor Interim Safe Storage (ISS) Project (BHI 2001). Following TSCA guidelines for handling PCB bulk waste, the strategy involved collecting any debris coated with dried paint that may contain PCBs, onsite consolidation of the debris in the Environmental Restoration Disposal Facility Containers (ERDF), transportation to, and disposal at ERDF. PCBs in dried paint are considered to be highly bonded and relatively immobile in this phase. Caulking materials that would potentially contain PCBs would have been used across the site, most likely in applications where a high level of heat resistance or additional insulation is required. Similar to the PCB in paint, PCBs in caulking materials would have a low likelihood of release to the environment due to their fixed adhesion to the caulk material.

\subsection{RIVER CORRIDOR USE}

Various sources for potential PCB contamination along the river corridor have been documented. The Hanford Site contained many electrical devices and other materials that, because of date of manufacture, may have contained PCBs. These include electrical transformers and capacitors, hydraulic and lubricating oils, light ballasts, heat-resistant paints, caulking and sealant, and some roofing in the form of asphalt shingles. However, this potential presence has not been confirmed by testing.

PCB fluids used in operational equipment would have been used in capacitors, transformers, and hydraulic equipment. Their physical properties of heat resistance and durability make them more desirable lubricants in hydraulic systems than cheaper, more common fluids. Spills from damaged or leaking equipment would be the primary way these fluids would enter the environment. In cases of leaks, the spill would be localized to relatively small areas. 


\subsubsection{Dust Control Applications}

The use of oils as a suppression agent of dust on primitive or unpaved roads has been a widely used practice in the United States. This practice became a vehicle for PCBs to come in contact with the environment. The potential exists that PCB containing oil was included in the oils used for road spraying prior to the ban in 1976. PCBs applied to soil in this manner would not readily migrate downward deep through the soil column; rather, they would bond with soil particles relatively close to the surface due to their low solubility in water and high particulate adhesion properties (USDHHS 2000).

A study of two roads, one in the 200 Area and the other near the Horn Rapids Dam, performed in 1996 by the Surface Environmental Surveillance Project (SESP), was conducted to test for the potential of PCBs in oil used in dust-suppression applications. Soil collection methods used in this road investigation involved two samples from each of two sampling locations. One surface sample and one subsurface composite sample of soil were collected at each location from 2 to $3 \mathrm{~cm}$ intervals until a final depth of 20 to $23 \mathrm{~cm}$ was reached,. Analytical results showed no detectable levels of Aroclors, where detection limits were less than EPA Region IX remediation goals (PNNL-11651).

Dr. Patton, senior research scientist with Pacific Northwest National Laboratory, has over 15 years experience researching and managing environmental monitoring programs at the Hanford Site. Dr. Patton was contacted (Patton, G.W., personal phone interview 7 May 2007) to discuss the scope of the Arc Loop Road investigation and reason for selecting the sampling locations (Patton 2007). PNNL-11651 states "based on past practice knowledge (R. G. Riley, personal communication) there was reason to suspect that PCBs may have been present in the dust suppression oil." The SESP team observed that visually the roads appeared to have been heavily oiled and that there was an "intact layer of oil/tar on top of the underlying soil surface" (PNNL-11651). The SESP team concluded that of the roads known across the site the two selected were good candidates to contain PCBs.

An EPA PCB inspection and notice of noncompliance (Rockwell 1984) confirmed that the Hanford Site Road, Track, Maintenance and Equipment Operations department used waste oils for dust control on roadways. A noncompliance finding indicated that Rockwell Hanford Operations had a "lack of controls to preclude PCB contamination in oil used for road oiling/dust control" (RHO 1984). Rockwell's resolution to this finding was issuance of an internal letter \#72500 83-433, C. A. McGee to T. R. Hendrix, "Requirements for PCB Analysis of Oil for Disposal." The letter issued in October 1983 required analysis of waste oil from each container prior to disposal, using the non-PCB material criterion of less than $1 \mathrm{ppm}$ in order for disposal as road oil (RHO 1984).

During a personal interview with R. G. Riley of Pacific Northwest National Laboratory on June 6, 2007, Riley's investigative discussions with Rockwell Hanford Operations employees confirming the oiling of specific Hanford Site roads before and after 1976 were reviewed and revealed oiled roads at the Hanford Site. The results of Riley's investigation led to identification of 4 roads likely to have been sprayed with oil containing PCBs, as well as 16 other roads known to have received waste oil. The Arc Loop roads were among the 16 identified as receiving oil as part of required upkeep due to research use during the 1960s (Riley, R. G., personal interview, June 6, 2007). 


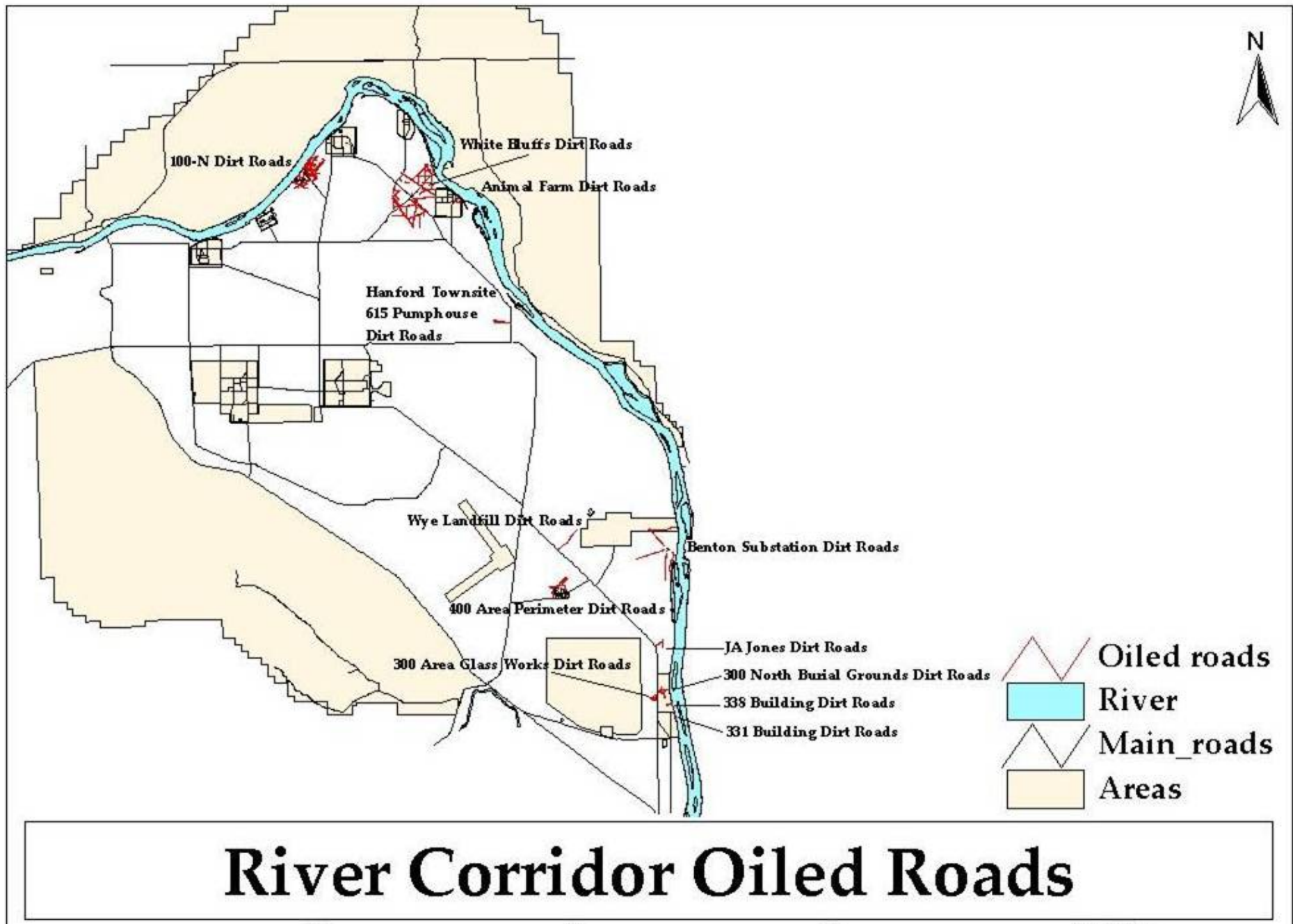

동 뭉

을

एक $\omega$

을요 온

于 퐁

के

은뭉

ํㅜㄹ 을 음

u

웅

고웡

的

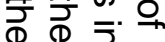

ㄱ. 능

$7 \quad$ ज 10

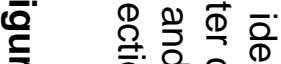

क

山 O

으 을

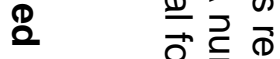

낑 궁

\%ั

흔. 몬

우웅

흐르으.

要

宽宫节

ㄱ. 은

는

궁

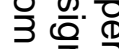

㧒

裉

त

焉兽

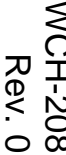


PCB fluids were used for three primary functions: (1) heat resistance, (2) insulating properties, and (3) high dielectric performance. Assuming PCB fluids perform their functions well, PCB fluids would not have been drained and changed out due to normal maintenance, as opposed to less expensive and less durable fluids such as motor oil. During Riley's discussions with the manager of the Hanford Site Road and Track Maintenance Department, mixing of PCB oil with non-PCB oil prior to road application was confirmed. However, the concentration of PCBs in this type of mixture is not known.

Formerly oiled roads at the Hanford Site remain a potential location for PCB contamination. Analytical data from only one of the roads oiled during the time when unregulated PCB disposal occurred shows no of PCBs present in the soil samples. If PCBs were present in oils applied to the roads identified in Table 6 , their mobility through the soil column or to the river is not likely. Contamination would be confined to the surface or shallow subsurface.

Table 6. Hanford Site Oiled Roads. (2 Pages)

\begin{tabular}{|l|c|c|c|}
\hline \multicolumn{1}{|c|}{ Oiled Roads } & PCBs Likely & $\begin{array}{c}\text { PCBs } \\
\text { Uninvestigated }\end{array}$ & $\begin{array}{c}\text { PCBs } \\
\text { Investigated }\end{array}$ \\
\hline $\begin{array}{l}\text { Behind 1100 Area, east of } \\
\text { railroad tracks }\end{array}$ & $\mathrm{x}$ & & \\
\hline Yard west of 2101-M & $\mathrm{x}$ & & \\
\hline $\begin{array}{l}\text { Hanford townsite near } \\
615 \text { pumphouse }\end{array}$ & $\mathrm{x}$ & $\mathrm{x}$ & \\
\hline Benton substation roads & & $\mathrm{x}$ & \\
\hline $\begin{array}{l}\text { White Bluffs townsite various } \\
\text { roads }\end{array}$ & & $\mathrm{x}$ & \\
\hline 100-N roads & & $\mathrm{x}$ & \\
\hline $\begin{array}{l}\text { East of Route 4, north of the } \\
\text { road to West Lake Pond }\end{array}$ & & $\mathrm{x}$ & \\
\hline Airstrip west of 200 East Area & & $\mathrm{x}$ & \\
\hline $\begin{array}{l}\text { Outside of 200 East Area } \\
\text { perimeter fence }\end{array}$ & & $\mathrm{x}$ & \\
\hline Road to Wye landfill & & $\mathrm{x}$ & \\
\hline $\begin{array}{l}\text { Outside of Fast Flux Test } \\
\text { Facility perimeter fence }\end{array}$ & & $\mathrm{x}$ & \\
\hline Road to 300-N burial ground & & $\mathrm{x}$ & \\
\hline North of 338 Building & & & \\
\hline JA Jones roads & & & \\
\hline Animal farm roads & & & \\
\hline $\begin{array}{l}\text { Between 331 and Columbia } \\
\text { River }\end{array}$ & & & \\
\hline $\begin{array}{l}\text { Roads between 200 West Area } \\
\text { and 200 East Area }\end{array}$ & & & \\
\hline $\begin{array}{l}\text { Road off of Army Loop Road to } \\
\text { central landfill }\end{array}$ & & & \\
\hline
\end{tabular}


Table 6. Hanford Site Oiled Roads. (2 Pages)

\begin{tabular}{|l|c|c|c|}
\hline \multicolumn{1}{|c|}{ Oiled Roads } & PCBs Likely & $\begin{array}{c}\text { PCBs } \\
\text { Uninvestigated }\end{array}$ & $\begin{array}{c}\text { PCBs } \\
\text { Investigated }\end{array}$ \\
\hline Road to 300 Area glass works & & $\mathrm{x}$ & \\
\hline Arc Loop roads & & & $\mathrm{X}$ \\
\hline
\end{tabular}

\subsubsection{Evaluated Waste Sites}

Several locations at the Hanford Site have had known spills or releases of PCBs and have been documented as Hanford waste sites. Site descriptions, locations, process descriptions, release potentials, comments, and waste cleanup activities have been recorded in WIDS. WIDS is a database designed to capture site investigation information and catalog that information for both hazardous and nonhazardous sites. Other waste sites containing PCBs, such as hazardous waste storage areas and underground storage tanks, are addressed later in this document. There is some overlap between this section and the transformer discussion in Section 3.1.1.

3.2.2.1 Electrical. WIDS includes 14 waste sites at or related to electrical substations that are known or suspected to be contaminated with PCBs. Transformer inspections performed by Hanford Electrical Utilities beginning in 1980 identified the majority of these substation PCB sites. Table 7 lists these waste sites along with brief site descriptions, cleanup activities, and presence of PCBs.

Table 7. Investigation Summary of Electrical-Related PCB Sites.

\begin{tabular}{|c|c|c|c|}
\hline Waste Site & Site Description & Cleanup Activities & Presence of PCBs \\
\hline $600-58$ & $\begin{array}{c}\text { Substation oil/water } \\
\text { separator }\end{array}$ & $\begin{array}{c}\text { No releases or spills } \\
\text { observed }\end{array}$ & None found \\
\hline $600-60$ & Substation switchyard & Sampling only & Confirmed \\
\hline $600-61$ & Substation & Sampling only & None found \\
\hline $600-62$ & Substation & Sampling only & None found \\
\hline $600-195$ & Substation & Complete removal & None found \\
\hline $400-29$ & Transformers & 14 remain, 5 removed & Confirmed \\
\hline $300-37$ & $\begin{array}{c}\text { PCB leak adjacent to } \\
335 A\end{array}$ & Complete removal & Confirmed \\
\hline $300-231$ & $\begin{array}{c}\text { Vitrification test site } \\
\text { Transformer pad }\end{array}$ & $\begin{array}{c}\text { Transformers removed, } \\
\text { pad cleaned }\end{array}$ & Confirmed \\
\hline $100-$ N-35 & Substation & Sampling only & Confirmed \\
\hline $100-$ D-27 & Substation & Cleaned & Confirmed \\
\hline $100-$ H-24 & Substation & Cleaned & Confirmed \\
\hline $100-F-47$ & Substation & Demolished & None found \\
\hline $1607-D 5$ & Septic tank & Sampling only & Confirmed \\
\hline UPR-200-E-140 & $\begin{array}{c}211-B \text { PCB spill at bulk } \\
\text { chemical storage }\end{array}$ & Complete removal & Confirmed \\
\hline
\end{tabular}


As shown in Table 7, PCBs were confirmed at multiple electrical-related waste sites. In each case of confirmed PCB contamination the release was to soil, which was removed and sampled until PCB levels were reported below cleanup levels. Since PCB mobility downward through a soil column is limited, this method of excavation is a consistent practice at the Hanford Site. When applicable, waste site cleanup verification packages show that PCB migration downward beyond an initial subsurface zone of contamination does not occur.

Examples of vertical profiles of PCB contamination in Hanford Site soil are evident in the Cleanup Verification Package for 100-D-22 Sludge Pit (CVP-98-00001) and Cleanup Verification Package for the 600-23 Dumping Area (CVP-2001-00020). Excavation and cleanup verification sampling at each of these sites showed PCB concentrations dropping to undetectable levels within $1.8 \mathrm{~m}(6 \mathrm{ft})$ of the bottom of the engineered structure or the piece of leaking equipment at 100-D-22 and 600-23, respectively.

3.2.2.2 Disposal Areas. A total of 186 waste sites have been investigated for PCBs in soil. The majority of these locations are related to general dumping and disposal activities. Over half of these sites have been closed out through remediation or reclassification, based on physical or historical evidence that no hazardous material was or is present.

As part of remedial activities, interim closed-out waste sites confirmed for PCBs have been cleaned to the Washington Administrative Code levels mentioned above through excavation, demolition, or equipment removal. Most common cases of documented sites confirmed or suspected for release of PCBs have been from leaks, equipment disposal, or intentional dumping to surface soil. A discussion of chemical background on the nature of PCBs in the environment follows in later sections and will help illustrate that these spatially localized and relatively small volume releases leave little evidence of transport through the environment.

Figure 4 shows the locations of 67 waste sites in the 100 and 300 Areas where PCBs have been detected in soil samples. Detailed maps according to operable unit can be found in Appendix B. Waste sites associated with PCB soils include emergency dump basins, material dump sites, chemical dump sites, oil dump sites, city dumps, oil spills, leaks, tanks, and oil releases. These locations were identified based on results from field investigation samples collected prior to remediation, as well as post-remediation cleanup verification sampling. PCB data associated with these sites can be found in Appendix $C$. 


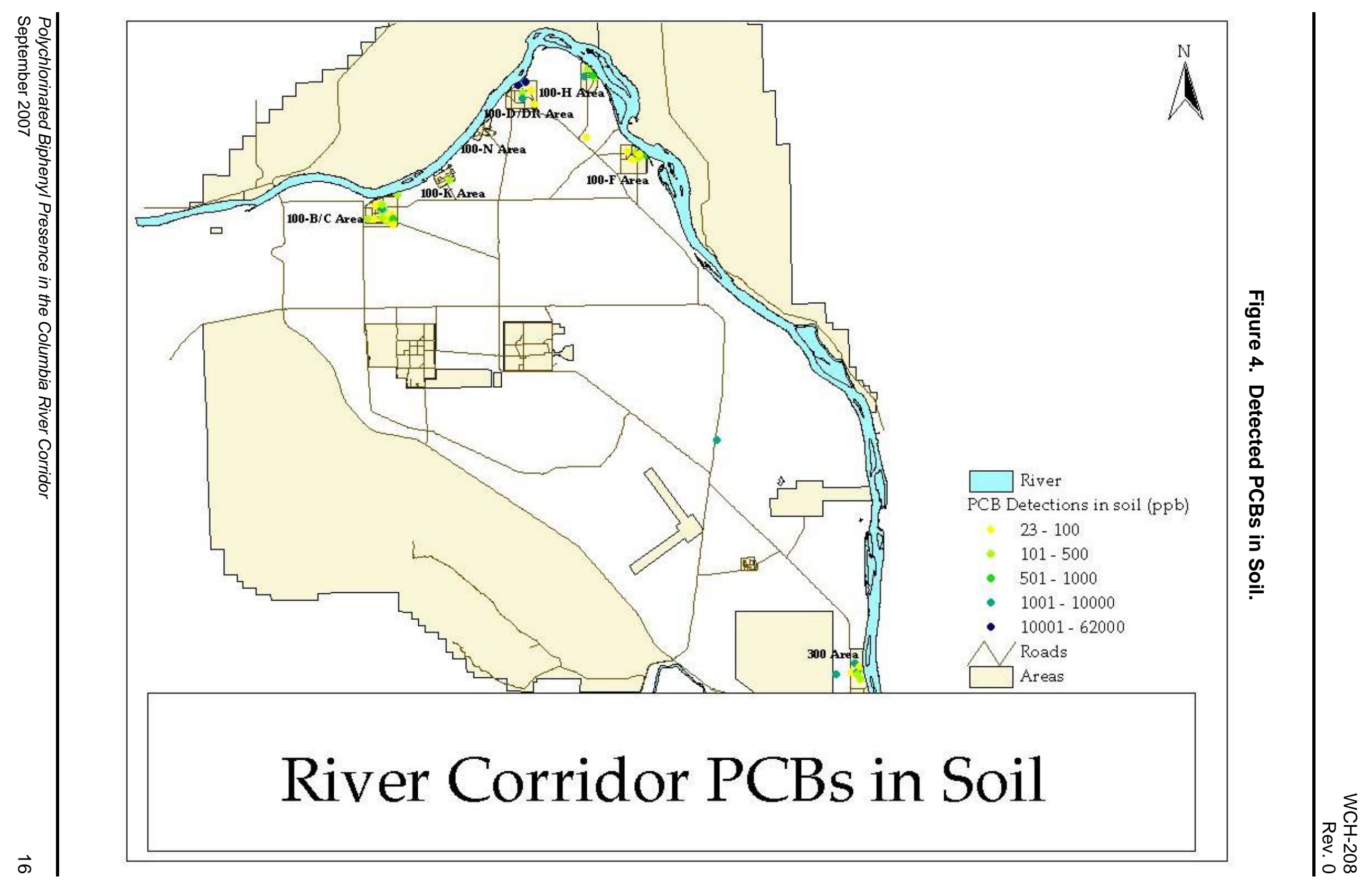




\subsubsection{Area Fuel Storage Basins}

Spent nuclear fuel storage basins at 100-N, 100-K, and 100-KE were large water-filled basins that stored irradiated fuel. Over time, a layer of sediment or sludge formed on the bottom of the basins. Waste characterization efforts involved sampling of the basin water and sediment for contaminants of concerns, which included PCBs. PCBs have been detected in the basin sludge at levels greater than $50 \mathrm{ppm}$. Cleanup of the basins required removal of the fuel and transfer to the 327 Building for interim storage. Water in the basins was also tested and revealed no PCBs detected above 1 ppb.

To ensure that no PCBs were transferred in the form of residual sediment contamination during fuel packaging, fuel remnant canisters were packaged under water on a table suspended above the sludge layer. During the packaging process, PCB sediment would be removed from the fuel; and once sealed, the fuel remnant canisters were hydrolazed to remove any residual sediment then radiologically decontaminated, also removing any PCBs (BHI 1998). This method for removal of PCBs was evaluated and validated by NES Government Services, LLC through a sampling and analysis study performed on $100-\mathrm{K}$ basin fuel packaging and removal activities.

Once cleaned and removed from the basin, swipe samples were collected from fuel remnant canisters. All samples were analyzed and results reported as less than the detection limit of $0.1 \mu \mathrm{g} / 100 \mathrm{~cm}^{2}$. NES Government Services concluded that "PCB contamination of the hardware through contact with $\mathrm{N}$ basin sediment is not expected to occur following waste cleaning methods (water wash) currently being implemented" (BHI 1997). Removal of the sludge sediment material remaining in the basins would be accomplished through filtration then disposal as PCB material under TSCA.

Leaks were discovered at the 100-KW and 100-KE basins and were believed to occur from 1974 until repair in 1979. Four groundwater monitoring wells were installed downgradient of the basins in 1980. No PCBs have been found in groundwater samples from these wells. Borehole soil sampling was conducted at a well installed approximately $40 \mathrm{~m}$ downgradient of the $100-\mathrm{KW}$ basin, where soil results showed no detectable levels of PCBs. The sampling that has occurred shows that any release of PCBs from leaking fuel storage basins at the 100-K Area has not reached groundwater, nor has there been significant lateral migration. During remediation of the basins, soil sampling closer in proximity to the area of leakage will reveal any release of PCBs that may have occurred.

\subsection{INLAND SOURCES}

Inland sources are primarily confined to the 200,400 , and 600 Areas, some of which have been discussed in preceding sections. Sources inland of the 100 and 300 Areas are discussed due to the potential for transportation to affect the 100 and 300 Areas. The PCB-containing materials and equipment described in Section 3.2 can also be found inland along with two additional sources, Hanford Site tank waste and facilities used to store PCB waste.

\subsubsection{Hanford Site Tank Waste}

The EPA, DOE, and Washington State Department of Ecology agreed upon and signed the Framework Agreement for Management of Polychlorinated Biphenyls (PCBs) in Hanford Tank Waste (Ecology et al. 2000). This agreement directed quantification of PCBs in double-shell 
and single-shell tanks to ensure vitrification plant waste acceptance limits and requirements of risk-based disposal approval are met. As a result the tank farm contractor formulated a PCB characterization program, establishing PCB inventories for all 177 underground storage tanks. Prioritization strategies and characterization scheduling can be found In the Fiscal Year 2004 PCB Characterization Plan for Tank Farm Waste (RPP-6693b).

As of July 2003, according to a prioritized characterization schedule has led to aqueous phase media analysis for PCBs in 52 tanks, with the remaining tanks awaiting characterization. PCBs were detected at very low levels in only one of those tanks. Levels detected were 4.3 and $1.8 \mathrm{ppb}$ for Aroclor-1248 and Aroclor-1254, respectively. One tank was observed as having a separable organic phase and analysis of that phase resulted in detectable levels of Aroclor-1254. This organic phase was adsorbed onto the solid phase after saltwell pumping. Analysis of solids revealed PCB detections in 15 out of 49 tanks. Table 8 illustrates the PCB distribution in Hanford underground storage tanks analyzed through July 2003 (RPP-6693a).

Table 8. Hanford Site Waste Tank PCB Summary.

\begin{tabular}{|l|c|c|c|}
\hline & \multicolumn{3}{|c|}{ Tank Media Analyzed } \\
\cline { 2 - 4 } & Aqueous & Organic & Solids \\
\hline Tanks analyzed & 52 & 1 & 49 \\
\hline Detections & 1 & 1 & 15 \\
\hline $\begin{array}{l}\text { Aroclors } \\
\text { detected }\end{array}$ & 1248,1254 & 1254 & $\begin{array}{l}1248^{\mathrm{a}} \\
1,254^{\mathrm{b}} \\
1,260^{\mathrm{a}}\end{array}$ \\
\hline $\begin{array}{l}\text { Levels detected } \\
\text { (ppm) }\end{array}$ & $0.0043,0.0018$ & 6.9 & $0.058-62.6$ \\
\hline
\end{tabular}

${ }^{a}$ Detected in only one of the total number of tanks analyzed.

${ }^{\mathrm{b}}$ Detected in all tanks with detectable levels.

In summary, a total of 17 tanks were identified as containing PCBs, in water and/or sediment, and all of these tanks contained the mixture Aroclor-1254. In 2 of the 17 tanks, Aroclor-1248 was also detected, and in one case Aroclor-1260 was detected. Assuming that tank waste confirmed for PCBs contained materials from any of the aforementioned sources (e.g., transformer oil, paint, caulking, $100-\mathrm{N}$ and $100-\mathrm{K}$ storage basins) and considering Aroclor persistence (described earlier), then Aroclors-1248, Aroclor-1254, and Aroclor-1260 would represent the most prevalent PCB mixtures on the Hanford Site, with Aroclor-1254 and Aroclor-1260 being the most prevalent. This conclusion is further supported by results of sampling conducted thus far, where the majority of PCB detections are that of Aroclor-1254 and Aroclor-1260. 


\subsubsection{Area Facilities}

The Fiscal Year 2003 PCB Characterization Plan for Tank Waste (RPP-6693a) identifies facilities that may have used PCBs in their operations. Those facilities include Plutonium Finishing Plant, 222-S Laboratory, B Plant/Waste Encapsulation and Storage Facility, and T Plant.

- $\quad$ Plutonium Finishing Plant: Part of Z Plant plutonium finishing and recovery facilities. PCBs were listed as contaminants of potential concern (COPCs) in the Z-Plant Source Aggregate Area Management Study Area Report (DOE/RL-91-58).

- 222-S Laboratory: Part of S Plant reduction oxidation facility. PCBs were not listed as COPCs in the S-Plant Aggregate Area Management Study Report (DOE/RL-91-60). PCBs were a component of laboratory waste generated at 222-S. PCBs were found in the hoods at the 233-S Plutonium Concentration Facility, part of the S Plant.

- $\quad$ B Plant Waste Encapsulation Storage Facility: PCBs listed as COPCs used in B Plant processes in the B-Plant Source Aggregate Area Management Study Report (DOE/RL-92-05).

- $\quad$ T Plant: Separations facility. PCBs were not listed as COPCs in the T-Plant Source Aggregate Area Management Study Area Report (DOE/RL-91-61).

Review of the documents cited above indicates no specific source of PCBs in a waste stream. However, PCBs would have been used in equipment at these facilities, which would have used the heat-resistant properties of the fluids.

Process ponds near the 200 Areas were investigated for PCBs that may have entered the ponds through cooling water from process facilities. The study addressing this potential issue is A Preliminary Survey of Polychlorinated Biphenyls (PCBs) in Aquatic Habitats and Great Blue Herons on the Hanford Site (PNL-5685). Theorized in the study was that a pathway for PCBs into aquatic habitats was Columbia River water pumped to process facilities for cooling water then discharged to B Pond, Gable Mountain Pond, and West Lake Pond. There is no outlet for water from these ponds, leaving only percolation and evaporation as avenues of release. Therefore, it was suspected that any PCBs present in process water would be found in pond sediment. PCBs were also found in fish samples collected from Gable Mountain Pond and the White Bluffs slough in the Columbia River at similar levels. The control for this study was a pond on the Wahluke Slope on the east side of the Columbia River. No PCBs were found in fish tissue or water from this pond, and low levels just above the detection limit for PCBs were found in the sediment. See Table 9 for a comparison of PCB levels found in Hanford pond media to PCBs from the Columbia River and Wahluke Slope Pond. PNL-5685 found PCBs in water and sediment from these ponds at levels equal to or less than levels found at other fresh water and sediment locations across the nation.

Sediment concentrations in B Pond and Gable Mountain Pond indicated that in both cases the highest concentrations, $230 \mu \mathrm{g} / \mathrm{kg}$ and $130 \mu \mathrm{g} / \mathrm{kg}$ respectively, were near the pipe inlet. For Gable Mountain Pond, a second study was conducted to look specifically at the distribution of PCBs in the pond. Sediment sampling throughout the pond provided enough results to plot concentrations that showed the pipe inlet was the primary source of PCBs, as concentrations decreased with distance from the inlet (PNL-5625). 
Table 9. PCB Concentrations in Water, Sediment, and Fish.

\begin{tabular}{|l|c|c|c|c|c|}
\hline \multicolumn{1}{|c|}{ Sample Type } & $\begin{array}{c}\text { White Bluffs } \\
\text { Slough } \\
\text { (Columbia } \\
\text { River) }\end{array}$ & $\begin{array}{c}\text { Gable } \\
\text { Mountain } \\
\text { Pond }\end{array}$ & B Pond & West Lake & $\begin{array}{c}\text { Wahluke } \\
\text { Slope Pond }\end{array}$ \\
\hline Water $^{\mathrm{a}}(\mu \mathrm{g} / \mathrm{L})$ & $<0.04-2.76$ & $<0.3-1.9$ & $1.39-3.75$ & $<0.3-0.4$ & $<0.5$ \\
\hline Sediment $(\mu \mathrm{g} / \mathrm{kg})$ & $\mathrm{ND}$ & $1-130$ & $6-230$ & $\mathrm{ND}-4$ & $\mathrm{ND}-2$ \\
\hline $\begin{array}{l}\text { Fish fat tissue } \\
(\mu \mathrm{g} / \mathrm{kg})\end{array}$ & 4.72 & $2.09-4.40$ & $\mathrm{NC}$ & $\mathrm{NC}$ & $<0.04$ \\
\hline
\end{tabular}

${ }^{a}$ Water samples were pumped through stainless steel columns filled with XAD-2 resin.

$\mathrm{NC}=$ No samples were collected.

ND = No PCBs were detected.

Source: PNL-5865, Table 3.

Possible links between PCB levels in the ponds and in the river are not indicative of Hanford Site-borne contamination returning to the river due to proximity and restricted transport of PCBs through the soil column. West Lake, B Pond, and Gable Mountain Pond are located more than $8 \mathrm{~km}$ (5 mi) from the Columbia River. No PCBs have been detected in the groundwater downgradient of the ponds, nor have there been any detected at any groundwater sampling locations in the 200 Areas. Groundwater as a pathway for PCBs (discussed later in Section 6.0) to the river from contamination located in the 200 Areas is not likely. Due to the similarities in PCB levels in Columbia River water and the pond water, a more likely scenario is that pond contamination was a result of introduction of river water.

\subsection{POTENTIAL NON-HANFORD SITE SOURCES}

\subsection{UPSTREAM CONDITIONS}

Various studies and reports discussed in more detail later in this document have described levels of PCBs in upper Columbia River water, fish, and sediment. The source of the Columbia River is Lake Columbia located at the foot of the Canadian Rockies of British Columbia. As a snowmelt-charged river, the Columbia travels through nine hydroelectric dams in Canada and Washington before reaching the Hanford Site. Although sources of PCBs are identified upstream of the Hanford Site, transportation of the contaminants to the Hanford Site would be drastically obstructed by the basin's hydroelectric dams, a point that is expanded on in Section 6.0.

The hydroelectric dams along the Columbia River are potential sources of PCBs. Because of the age of the facilities, PCB oil was likely present in the electrical equipment at each dam. The large amount of electrical equipment using the attractive dielectric properties of PCBs would make dams concentrated sources of PCBs. However, no information was obtained concerning historical practices or current conditions at these facilities. 
Other potential contributors to PCBs in the Columbia River are the five major tributaries to the Columbia River upstream of the Hanford Site: the Kootenai, Pend Oreille, Okanogan, Spokane, and Wenatchee Rivers. These tributaries present pathways for contamination from aluminum processing plants and pulp and paper mills. Total maximum daily load assessments have been performed for two of these four tributaries, the Okanogan and Spokane Rivers, to address PCB contamination.

Sediment concentrations at the Hanford Site, the Spokane River, and Okanogan River are being presented for regional comparison. A single sediment core sample was collected at the mouth of the Okanogan River and analyzed at seven intervals between 2 and $32 \mathrm{~cm}$. Aroclor-1254 was detected at all intervals with concentrations (0.89 to $2.84 \mathrm{ppb})$ generally increasing with depth (Peterschmidt 2004). Spokane River sediments were studied by Serdar and Johnson (2006) down to Lake Roosevelt, which revealed sediment levels ranging from 21 to $3,300 \mathrm{ppb}$. Levels decreased with proximity to Lake Roosevelt. A total of 11 sediment samples were collected from the Columbia River above Priest Rapids Dam, which showed no detectable levels of PCBs above a reporting limits ranging from 23 to 5,000 ppb. Forty Hanford Site sediment samples have been analyzed with 39 undetectable results less than reporting limits ranging from 11 to $47 \mathrm{ppb}$. The single detection of PCBs was at a concentration of $24 \mathrm{ppb}$.

Although there are confirmed sources of PCBs in Columbia River tributaries, their proximity to the Hanford Site makes them irrelevant as sources for Hanford Reach PCBs. The Okanogan and Spokane Rivers are located approximately 241 and 402 km (150 and $250 \mathrm{mi}$ ) upstream of the Hanford Site, respectively, with five and seven dams impeding sediment transport downstream to the Hanford Site.

Columbia River PCB data in sediment above the Hanford Site are limited; however, the data available do not show a continuous trail between Hanford Site PCB sediment concentrations and those upstream.

\subsection{PREVIOUS EVALUATIONS OF PCBS IN BIOTA}

\subsection{COLUMBIA BASIN FISH STUDIES}

The Columbia River Basin Fish Contaminant Survey (EPA 2002) documents a study performed between 1996 and 1998, in which a large suite of organic, inorganic, and radionuclide analytes were studied, including PCBs. The study covers the Columbia Basin confined to the north by Grand Coulee Dam, the Clearwater River to the east, just below Bonneville Dam to the west, and the Willamette River to the south.

One of the conclusions drawn from the study was that "fish collected from the Hanford Reach of the Columbia River and the Yakima River tended to have higher concentrations of organic chemicals than other study sites ... The maximum concentration for Aroclor-1254 was in a mountain whitefish (930 ppb) fillet sample from the Hanford Reach of the Columbia River. The white sturgeon fillet samples from the Hanford Reach of the Columbia River (study site 9U) had the highest concentration (200 ppb [SIC]) of Aroclor-1260 for all species and all sites." Results of the study also concluded that "many of the chemical residues in fish identified in this study 
were not unlike levels found in fish from other studies in comparable aquatic environments in North America" (EPA 2002).

Table 10 shows the range of PCBs detected in mountain whitefish and white sturgeon collected from regional rivers. Columbia River mountain whitefish fillets were collected only from a sampling area that EPA (2002) reports as the Hanford Reach. Additional mountain whitefish samples were collected from the Deschutes, Umatilla, and Yakima Rivers. All white sturgeon samples represented in Table 10 were collected downstream of the 100-K Area. In addition to the Columbia River, white sturgeon samples were also collected in the Snake River (EPA 2002).

Table 10. Columbia River Basin PCB Concentrations (ppb) in Mountain Whitefish and White Sturgeon Fillets.

\begin{tabular}{|l|c|c|c|c|}
\hline & Number Sampled & Aroclor-1242 & Aroclor-1254 & Aroclor-1260 \\
\hline $\begin{array}{l}\text { Mountain Whitefish } \\
\text { Okanogan River }\end{array}$ & 9 & ND & $2.9-19$ & $2.1-18$ \\
\hline $\begin{array}{l}\text { Mountain Whitefish } \\
\text { Spokane River }\end{array}$ & 30 & $19-25$ & $60-1,490^{\mathrm{a}}$ & \\
\hline $\begin{array}{l}\text { Mountain Whitefish } \\
\text { Hanford Reach }\end{array}$ & 3 & ND & $21-30$ & ND \\
\hline $\begin{array}{l}\text { Mountain Whitefish } \\
\text { Deschutes }\end{array}$ & 3 & ND & ND & 22 \\
\hline $\begin{array}{l}\text { Mountain Whitefish } \\
\text { Umatilla }\end{array}$ & 10 & ND & $53-58$ & $98-130$ \\
\hline Mountain Whitefish Yakima & 30 & ND & $15-1,200$ & ND \\
\hline $\begin{array}{l}\text { Mountain Whitefish Snake } \\
\text { River }\end{array}$ & 2 & ND & $170-210$ & $190-210$ \\
\hline $\begin{array}{l}\text { White Sturgeon } \\
\text { Hanford Reach }\end{array}$ & 4 & ND & $23-160$ & $29-100$ \\
\hline $\begin{array}{l}\text { White Sturgeon } \\
\text { Downstream }\end{array}$ & 14 & $26-48$ & $33-73$ \\
\hline $\begin{array}{l}\text { White Sturgeon } \\
\text { Snake River }\end{array}$ & 4 & ND & \\
\hline
\end{tabular}

${ }^{a}$ Results for Spokane River were reported as total Aroclors, individual Aroclors were not assigned. $\mathrm{ND}=$ Analyte was not detected above reporting limits.

Source: 1) Lower Okanogan River Basin DDT and PCBs Total Maximum Daily Load (Peterschmidt 2004).

2) PCBs, PBDEs, and Selected Metals in Spokane River Fish, 2005 (Serdar and Johnson 2006).

3) Columbia River Fish Contaminant Survey (EPA 2002).

4) Archives of Environmental Contamination and Toxicology (Perry 1979).

Mountain whitefish and white sturgeon both migrate to and from the Hanford Reach. Mountain whitefish travel upstream to Priest Rapids Dam and down the Columbia to the mouth of the Yakima and up the Yakima River (Fickeisen et al. 1980). White sturgeon travel upstream as far as Priest Rapids Dam and all throughout the McNary pool (PNL-6795). These roaming characteristics would make the fish sampled susceptible to sources tens of miles upstream and downstream of collection locations. Table 11 shows PCBs found in one sediment sample from the Hanford Reach as well as two samples downstream of the Hanford Site. 
In their study of PCBs in the Spokane River, Serdar and Johnson (2006) plotted fish tissue data together by species and river section. By studying the tissue results by river section they concluded that compared to historical levels, PCB concentrations in fish appear to have decreased in all parts of the Spokane River except the Mission Park reach (Serdar and Johnson 2006).

Table 11 compares all mountain whitefish and white sturgeon samples collected in the main stem of the Columbia River with fish from the Spokane River, statewide fish, and nation-wide fish samples. Mountain whitefish and white sturgeon are represented because they show the highest concentrations of all fish study in EPA (2002). EPA (2002) provides single species comparisons similar to Table 11, but for all fish studied. These data span a 15-year time period and offer a broad view of PCB concentrations in a range of fish species collected from rivers, lakes, and streams (Johnson 2001).

Table 11. National, Statewide, Spokane River, and Columbia River Total PCB Levels in Fish (ppb).

\begin{tabular}{|l|c|c|c|c|c|c|}
\hline \multicolumn{1}{|c|}{ Study } & Investigator & Year & $\begin{array}{c}\text { Samples/ } \\
\text { Sites }\end{array}$ & Median & $\begin{array}{c}\mathbf{8 5}^{\text {th }} \\
\text { Percentile }\end{array}$ & Max. \\
\hline $\begin{array}{l}\text { National Contaminant } \\
\text { Biomonitoring Program }\end{array}$ & USFWS & 1984 & $112 / 321$ & 390 & $\mathrm{nr}$ & 6,700 \\
\hline $\begin{array}{l}\text { National Study on } \\
\text { Chemical Residues in } \\
\text { Fish }^{\mathrm{b}}\end{array}$ & EPA & $1986-87$ & $\mathrm{nr} / 362$ & 209 & $\mathrm{nr}$ & 23,800 \\
\hline $\begin{array}{l}\text { National Water Quality } \\
\text { Assessment Program }\end{array}$ & USGS & $1992-94$ & $213 / \mathrm{nr}$ & $<50$ & 356 & $\mathrm{nr}$ \\
\hline $\begin{array}{l}\text { Washington State } \\
\begin{array}{l}\text { Pesticide Monitoring } \\
\text { Program and other } \\
\text { studies }\end{array}\end{array}$ & Ecology & $1992-98$ & $33 / 78$ & 36 & 115 & 379 \\
\hline $\begin{array}{l}\text { Spokane River Whole } \\
\text { body } \\
\text { Fillets }\end{array}$ & Ecology/USGS & 1999 & $\begin{array}{c}10 / 4 \\
52 / 4\end{array}$ & $\begin{array}{l}380 \\
143\end{array}$ & 390 & 1880 \\
\hline $\begin{array}{l}\text { Columbia River Fish } \\
\text { Contaminant Survey } \\
\begin{array}{l}\text { Whole body } \\
\text { Fillets }\end{array}\end{array}$ & EPA & $1996-98$ & $\begin{array}{c}11 / 7 \\
19 / 9\end{array}$ & $\begin{array}{l}106 \\
120\end{array}$ & 190 & 280 \\
\hline
\end{tabular}

Source: Ecology (2001).

References:

Ecology = Washington State Department of Ecology

EPA = U.S. Environmental Protection Agency

NR $\quad=$ not reported

USFWS $=$ U.S. Fish and Wildlife Service

USGS = U.S. Geological Society

When comparing the Columbia River with other water bodies in Washington State, Table 11 shows that PCB levels in fish are above average and that the Columbia River is home to some of the higher concentrations in the state. However, when compared to the Spokane River, the Columbia is shown to have half or less than half the levels of PCBs in fish. Compared to national PCB fish data, the Columbia River has half the average PCB levels and 6 to 20 times lower maximum contaminant concentrations. 
PCB concentrations in fish collected during the late 1990s in the Columbia River were above statewide average concentrations, but less than those found at the Spokane River and during nationwide studies. The elevated concentrations reported in EPA (2002) were collected upstream and within the Hanford Reach; however, the species examined are known to travel throughout the McNary pool, to and from the Hanford Reach. Because of the migratory nature of these species, the dynamics of the Columbia River system, and potential sources of PCBs, identifying a point source responsible for these results is unlikely.

\subsection{RIVER CORRIDOR SCULPIN AND SUCKER STUDIES}

Although studies discussed up to this point have included the Hanford Reach, recent DOE studies of Hanford Site fish are unique in that they involved almost exclusively sculpin and sucker samples. Collection of these samples took place as part of the 100-B/C Pilot Project and the 100 and 300 Area Risk Assessment, spanning the past 4 years. Roughly 100 samples were collected and analyzed for PCBs resulting in six detections ranging from 14 to 115 ppb, with detection limits near $5 \mathrm{ppb}$. Those six with detectable levels were recently reviewed by the analytical laboratory after inquiry as to the meaning of an estimated qualifier. Discussions with the chemist, summarized in Appendix D, revealed a low level of confidence that the results reported for the six samples were in fact representative of the Aroclor indicated. Subsequent reevaluation of the original data for presence and estimated levels of congeners present confirmed the presence of PCB congeners and the concentrations originally reported.

100 fish samples made up of two species collected throughout the Hanford Reach are a sample population large enough to lend itself to risk-based analysis. However, many of the detection levels range from 0.2 to $6.1 \mathrm{ppm}$, orders of magnitude above various risk based health criteria and screening values. Seidars et al. (2006) references 40 CFR 131.36 criteria, the National Toxics Rule, and EPA screening values as levels protective of human health for contaminants detected in fish tissue. National Toxics Rule criteria set protective levels of PCBs in fish tissue at $5.3 \mathrm{ppb}$, where EPA screening values are set at 2.45 and $20 \mathrm{ppb}$ for subsistence and recreational fishers.

Although there is a large amount of data on sculpin and suckers from the Hanford Site, reporting limits above relevant health criteria cause those data points to be marginally useful.

Investigation into this issue has led to a supplemental sampling effort for sculpin and suckers in the Hanford Reach. The effort has been initiated and will take place in September 2007. Samples from 12 locations will be analyzed for PCB congeners.

\subsection{RIVER CORRIDOR PCB FATE AND TRANSPORT}

The fate and transport of PCBs throughout the river corridor is a function of regional environmental conditions. Transportation of PCBs is limited due to the chemical properties of the compounds. These limitations lead to broken pathways to potential receptors, shown in the conceptual site model (Figure 5). 


\subsection{GROUNDWATER MIGRATION}

The Hanford Environmental Information System (HEIS) is a database that includes analytical results for groundwater samples collected from the site. HEIS groundwater results dating back to 1985 include a period of overlap between the discovery of PCBs in the submersible Peabody Barnes pumps and subsequent removal of those pumps. Among unsampled wells, Table 5 shows that of the wells containing Peabody Barnes pumps that have been sampled for PCBs in groundwater, none have resulted in PCBs above 1 ppb.

Between 1985 and 2007 more than 2,000 groundwater samples were analyzed for PCBs from across the Hanford Site. Only one sample showed detectable levels of PCBs, $8.3 \mathrm{ppb}$ of Aroclor. The sample was collected from well 199-H4-10 in the 100-H Area. The well is located approximately $122 \mathrm{~m}$ (400 ft) east of 1607-H2 septic tank and approximately $160 \mathrm{~m}$ from the

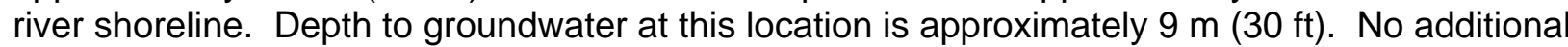
groundwater samples have been analyzed for PCBs from this well. A map of the 100-H Area in Appendix B shows the location of well 199-H4-10, near the 1607-H2 septic tank.

Aside from the single aforementioned detection, there are a large number of data that show that the lack of detected PCBs in groundwater reflects the physical and chemical properties of PCBs. The hydrophobic properties along with the high partition coefficient $\left(\mathrm{K}_{\mathrm{ow}}\right)$ indicate that PCB contamination would be retained in upper surface and subsurface soils. These properties lower the effects of the driving force of water percolation and contaminant transport through the soil column. Therefore, PCBs would not reach the river through groundwater, and any detected PCBs in sediment or surface water would be the result of past-practice direct discharge to the river, land surface contaminant migration, or upstream conditions. The anomalous groundwater detection mentioned above should be further investigated to confirm the presence or absence of PCBs at this location.

\subsection{RIVER TRANSPORT MECHANISMS}

Mechanisms for transportation of PCBs to the Hanford Site, and beyond, are sediment and surface water carried downstream by the Columbia River. As described in Section 2.0, PCB residue is more likely to be found adsorbed to organic material such as that found in sediment, and less likely to be detected in surface water. This section presents the variables that affect the transport of these mechanisms, and the likelihood of contamination at the Hanford Site due to upstream sources.

\subsubsection{Sediment Transport}

Pathways for PCBs to enter the river have been previously discussed and identified as direct discharge to the Columbia River or its tributaries. Considering water solubility and volatilization rates, it is possible to understand the potential media forms in which different PCB mixtures might reside during transport down the Columbia River. Mixtures with lower levels of chlorination are more soluble and therefore more likely to be detectable in river water. Conversely, PCBs with greater chlorination are less soluble and would more likely be found fixed to sediment and could be found during times of transport of such media. River transport of sediment material takes place during times of high flow in the spring and early summer, when high levels of suspended solids are visible. These PCB sediments would tend to fall out of the current and likely accumulate at locations of low current. Depositional areas where PCB 
sediment might be found include sloughs, eddies, islands, and areas of backwater behind downstream dams.

Table 12 shows three sections of the Spokane River along with three sections of the Columbia River. Data for the Spokane River were gathered from Johnson (2001), and Columbia River data were gathered from the Hanford Site Environmental Restoration database, PNL-10535, and PNL-8479. The point sources identified by the Washington State Department of Ecology as PCB contributors to the Spokane River are found in the section above Upriver Dam (Golding 2002). Table 12 presents comparisons of Columbia River sediments with Spokane River sediments. The table also shows decreasing PCB concentrations downstream of release sources where two dams administer water flows into the Long Lake section of the river.

Table 12. PCB Concentrations in River Sediment (ppb dry weight).

\begin{tabular}{|l|c|c|c|c|c|c|}
\hline \multicolumn{1}{|c|}{ Study Area } & Investigator & $\begin{array}{c}\# \\
\text { Detects }\end{array}$ & $\begin{array}{c}\text { \# Non- } \\
\text { Detects }\end{array}$ & $\begin{array}{c}\text { Reporting } \\
\text { Limit }\end{array}$ & Median & Max. \\
\hline $\begin{array}{l}\text { Spokane River } \\
\text { Above Upriver } \\
\text { Dam }\end{array}$ & Ecology & 11 & 1 & 17 & 1672 & 3000 \\
\hline $\begin{array}{l}\text { Spokane River } \\
\text { Upriver Dam to } \\
\text { Monroe Dam }\end{array}$ & Ecology & 5 & 0 & 3.6 & 147.5 & 390 \\
\hline $\begin{array}{l}\text { Spokane River } \\
\text { Long Lake }\end{array}$ & Ecology & 6 & 0 & 2 & 37.5 & 53 \\
\hline $\begin{array}{l}\text { Columbia River } \\
\text { Above Priest } \\
\text { Rapids Dam }\end{array}$ & DOE, PNL & 0 & $4^{\mathrm{a}}$ & $23-34$ & $\mathrm{ND}$ & $\mathrm{ND}$ \\
\hline $\begin{array}{l}\text { Columbia River } \\
\text { Hanford Reach }\end{array}$ & DOE, PNL & 1 & 39 & $11-47$ & 24 & 24 \\
\hline $\begin{array}{l}\text { Columbia River } \\
\text { Below Hanford to } \\
\text { McNary }\end{array}$ & DOE, PNL & 2 & 26 & $5.6-100$ & 12 & 13 \\
\hline
\end{tabular}

a Seven additional samples were collected above Priest Rapids Dam; however, elevated reporting limits of 5 ppm make them less relevant to this discussion.

ND = PCBs were not detected

$\mathrm{PNL}=$ Pacific Northwest Laboratory

Spokane River sediment samples collected above Upriver Dam were collected just upstream in close proximity to the dam, the initial area of deposition downstream of release sources. The declining PCB concentrations downstream of Upriver Dam are significant in that they provide evidence that dams are able to sequester PCB-contaminated sediment and provide a cascading effect on contaminant concentrations.

Deposition of contaminated sediment above dams, as shown in the Spokane River, leads to the conclusion that releases from that river would not likely have an effect as far downstream as the Hanford Site. Concentrations above Priest Rapids Dam indicate no sources for release of PCBs directly above that dam. Therefore, any detections found downstream of the dam would be a result of releases downstream of the dam. 
As shown in Table 12, one sediment sample was collected that had a detectable level of PCBs throughout the Hanford Reach. This sample was collected from the shoreline upstream (west) of the 100-N Area and was reported to have an Aroclor-1254 concentration of $24 \mathrm{ppb}$ less than two times the reporting limit for that sample of $14 \mathrm{ppb}$. The other samples collected and analyzed around the same time period as the $24 \mathrm{ppb}$ sample had reporting limits ranging from 11 to $47 \mathrm{ppb}$, placing the mean reporting limit at $29 \mathrm{ppb}$. Because there were no additional samples collected at the same location as the $24 \mathrm{ppb}$ detection and the results are less than two times the reporting limit, further investigation is needed to assess the significance of this detection in identifying a release source.

\subsubsection{Surface Water Transport}

Surface water is not expected to be a significant transport mechanism for PCBs, due to the low solubility of site-related Aroclors. There is limited surface water data for PCBs in the Columbia River. Data are presented in Table 13 to show that only low levels (sub-ppb) were detected from an area known to have high levels (ppm) of PCB contamination in sediment and fish (Spokane River). No detectable levels of PCBs in surface water at the Hanford Site are expected since the Spokane River, having much higher concentrations in fish and sediments, had surface water levels less than $1 / 100$ of a ppb. The conclusion is that surface water as a transport mechanism of PCBs is not significant based on data from a system known to have PCB contamination.

Table 13. PCB Concentrations in Surface Water (ppb).

\begin{tabular}{|l|c|c|c|c|c|c|}
\hline \multicolumn{1}{|c|}{ Study Area } & Investigator & $\begin{array}{c}\# \\
\text { Detects }\end{array}$ & $\begin{array}{c}\text { \# Non- } \\
\text { Detects }\end{array}$ & $\begin{array}{c}\text { Reporting } \\
\text { Limit }\end{array}$ & Median & Max. \\
\hline Spokane River & Ecology & $5^{\mathrm{a}}$ & 1 & 0.00009 & 0.00056 & 0.00125 \\
\hline $\begin{array}{l}\text { Columbia River } \\
\text { Hanford Reach }\end{array}$ & DOE & 0 & 39 & 0.4 & ND & ND \\
\hline
\end{tabular}

${ }^{a}$ Spokane River surface water sample were collected by diffusing PCBs onto semi-permeable membrane devices, then analyzed for congeners, results were summed for total PCB concentrations.

DOE = U.S. Department of Energy

Ecology $=$ Washington State Department of Ecology

$\mathrm{ND} \quad=$ PCBs were not detected

Because of the tendency for PCBs to bind to organic matter, the primary transport media for PCBs is river sediment. The Hanford Reach section of the Columbia River has a small number of depositional areas that could harbor PCB-contaminated sediment. As presented in previous sections, there are no records of direct releases to the river and no evidence of contamination to groundwater. Therefore, Columbia River sediment contamination from these pathways is broken. However, there are a limited number of uninvestigated areas of confirmed and potential land surface contamination that could potentially to reach the river and be found in sediment.

\subsection{OVERLAND TRANSPORT AND MIGRATION}

Overland flow of contaminants involves windblown dust, surface water runoff, and global transport. Low volatilization rates of Aroclors used at the Hanford Site exclude soil-to-air transfer as a major pathway for transport. Windblown dust and surface water runoff would have 
limited effects on the transport of PCBs, high partition coefficient, and low solubility of the compounds.

Oiling of dirt roads for dust suppression was a method of oil disposal practiced at the Hanford Site. Just as the purpose of the act intends, wind would only transport oiled sand and dust particles a short distance from the site of application. Likewise, PCB oils spilled, leaked, or applied directly to surface soils would act as a dust-suppressing agent, adsorbing to organic material or coating less organic sand particles. In this case, potential for wind transport would be low.

Surface water runoff from site with surface soil contamination would contribute to migration, but only slightly as the compounds would cause a hydrophobic condition. Migration even a short distance becomes relevant when contaminated sites are in close proximity to the Columbia River. Section 3.0 identified areas of confirmed PCB releases to the soil at waste sites, and potential releases to soil through dirt roads oiled with PCB-contaminated oils. A spatial analysis of waste sites with PCBs detected in soil led to identification of 19 waste sites within $305 \mathrm{~m}$ $(1,000 \mathrm{ft})$ of the river. Surface soil contamination at these sites has the potential through surface water runoff to impact the river. However, all of these sites were either burn pits or sites that received PCB contamination through below-grade releases. Oiled roads in close proximity to the river include the road near the 331 Building, the 338 Building, the Benton substation, the animal farm, and some roads in the White Bluffs town site and 100-N Area. Appendix A shows these sites in more detail.

Figure 5 shows broken and unbroken pathways for PCB contamination to reach human and ecological receptors. There are no major transport mechanisms for Hanford Site PCBs, such as groundwater flow, surface water flow, and sediment deposition because the pathways from release to those are broken generally due to the hydrophobic, high partition coefficients of the compounds. 
Figure 5. Conceptual Site Model for PCB Migration and Exposure.

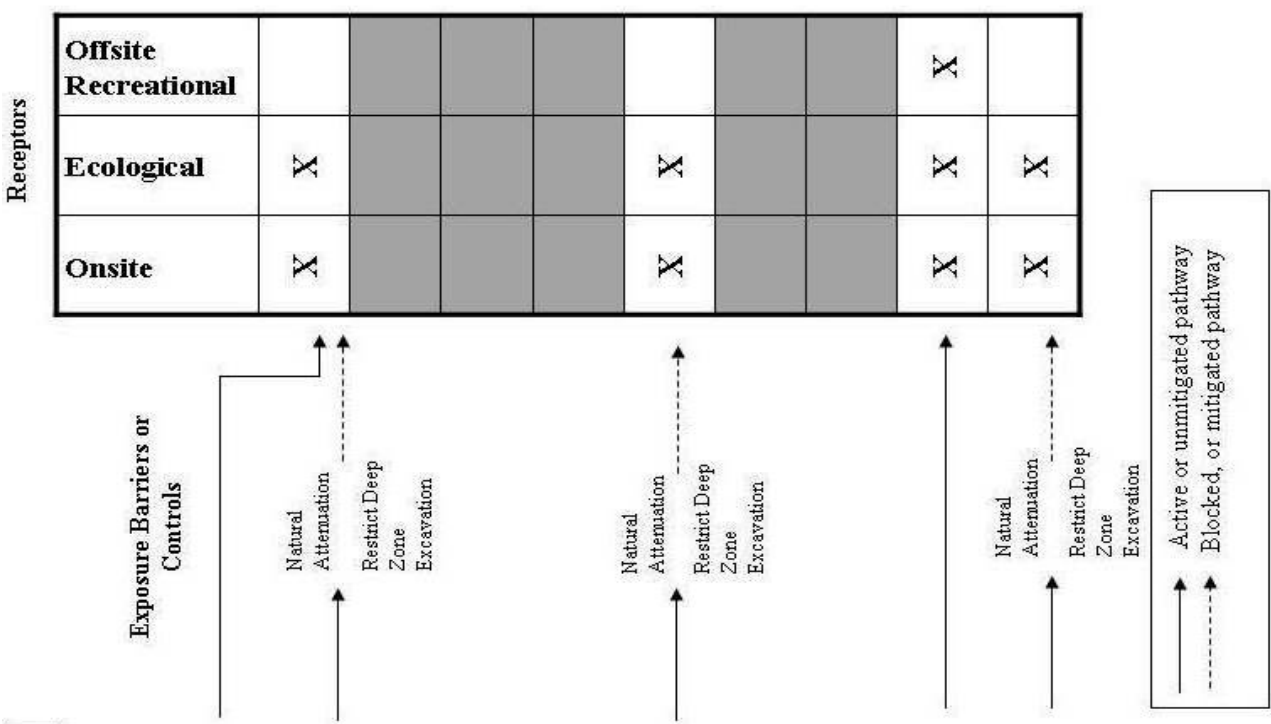

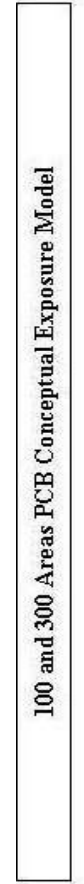
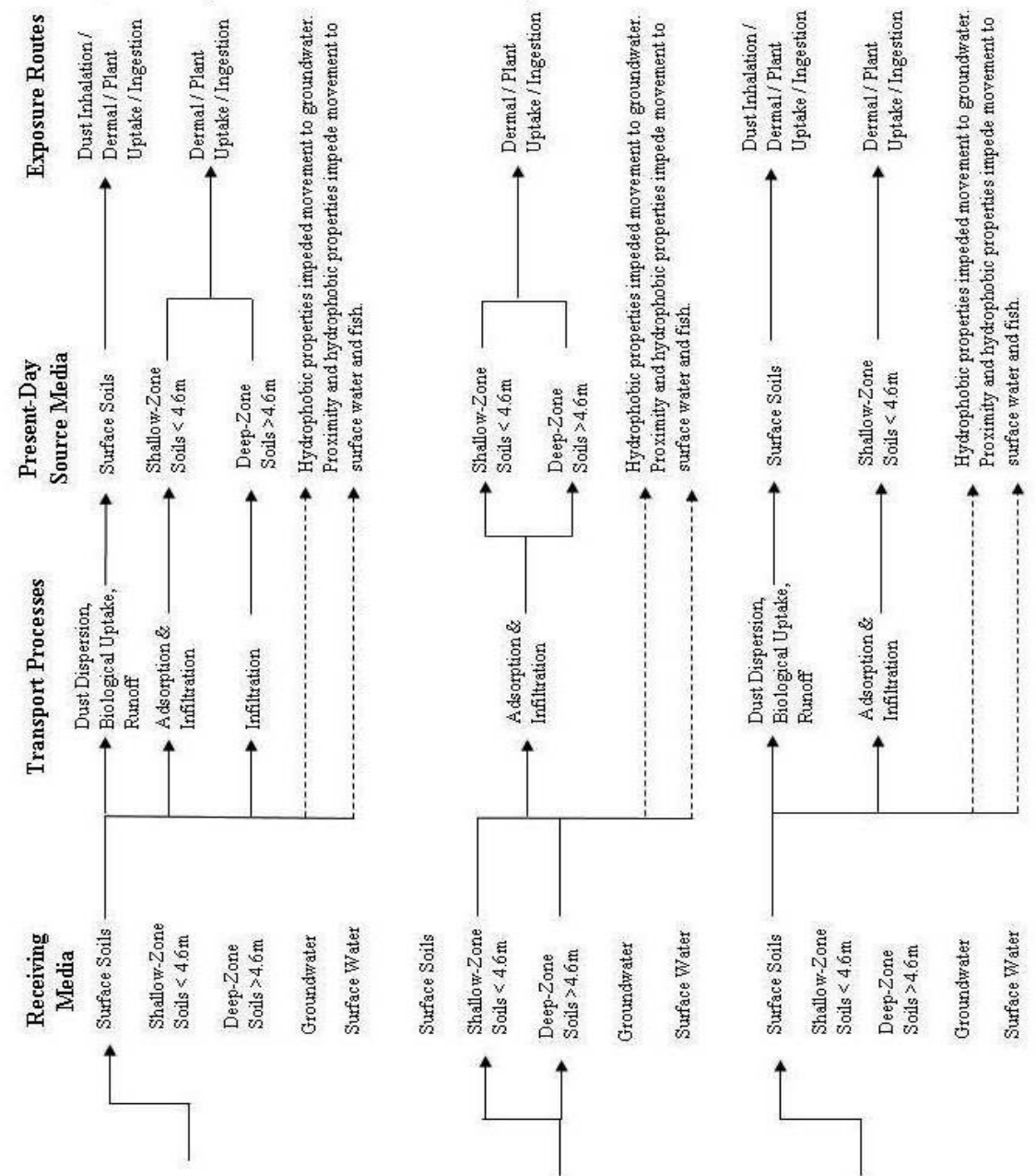

II: III
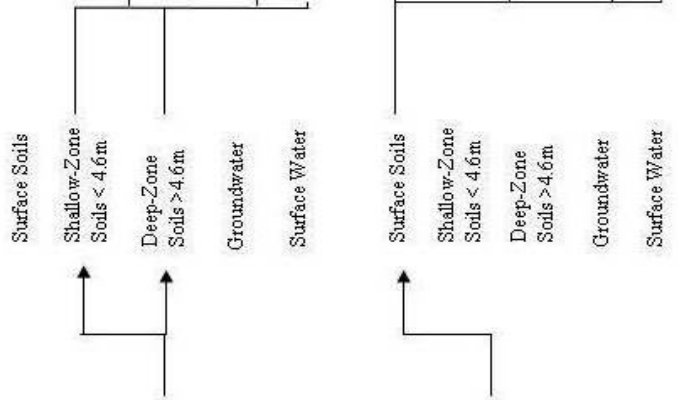


\subsection{ANALYTICAL METHODS}

Sensitivity of analytical methods applied during PCB analysis is the most important factor in determining levels of contamination, performing risk analysis, and making remedial decisions. Currently, two EPA-approved methods are commonly used for the analysis of PCBs, and both are suitable for risk assessment and subsequent decision making. EPA Method 8082 isolates and identifies Aroclors by gas chromatography and electron capture (GC-ECD), and EPA Method 1668 isolates and identifies congeners by high-resolution gas chromatography and mass spectrometry (HRGC-HRMS). Both methods rely on appropriate sample preparation techniques and the skills of experienced analysts. Table 14 lists some of the factors to consider when choosing the appropriate analytical method.

Table 14. Comparison of Options for PCB Analysis.

\begin{tabular}{|c|c|c|c|}
\hline & $\begin{array}{l}\text { Sensitivity Total } \\
\text { PCBs (ppb) }\end{array}$ & Method Performance & Cost (\$) \\
\hline $\begin{array}{l}\text { Aroclor Analysis } \\
\text { (8082) } \\
\text { GC-ECD }\end{array}$ & $10-1,000$ & $\begin{array}{l}\text { PROS - Over-estimations lead to } \\
\text { conservative results for decision making. } \\
\text { The most practiced of available methods. } \\
\text { Much historical aroclor data for comparison. } \\
\text { Cost savings. More ecotoxicity data } \\
\text { available for aroclors than for congeners. } \\
\text { CONS - Over-estimations and under- } \\
\text { estimations due to interferences from } \\
\text { complex matrices (hydrocarbons, proteins, } \\
\text { lipids, etc). Issues achieving desired } \\
\text { reporting limits due to interferences and/or } \\
\text { sample preparation procedures (limited } \\
\text { sample mass, poor concentration } \\
\text { techniques). Requires expertise to identify } \\
\text { aroclor patterns degraded by environmental } \\
\text { conditions. Increased difficulty identifying } \\
\text { multiple mixtures in the same sample. }\end{array}$ & $100-300$ \\
\hline $\begin{array}{l}\text { Congener Analysis } \\
(1668 A) \\
\text { HRGC-HRMS }\end{array}$ & $0.00024-0.024$ & $\begin{array}{l}\text { PROS - High sensitivity reduces } \\
\text { interferences, enables separation of } \\
\text { congeners from interfering hydrocarbons, } \\
\text { proteins, lipids. Most accurate quantitation } \\
\text { of individual congeners. Aroclor } \\
\text { concentrations can be more accurately } \\
\text { estimated based on congener } \\
\text { concentrations (list dependent). Lower } \\
\text { reporting limits. } \\
\text { CONS - High level of expertise required for } \\
\text { analysis, leaves limited number of vendors } \\
\text { offering the service. Toxicity information is } \\
\text { limited on individual congeners. Greater } \\
\text { effort in data reduction, QA, and processing. } \\
\text { Expensive. }\end{array}$ & $750-1000$ \\
\hline
\end{tabular}


Historical analyses of PCBs at the Hanford Site have employed the Aroclor method, which depending on the matrix (groundwater versus fish tissue) has led to suitable as well as irrelevant results. The Aroclor data compiled to this point offer a large corpus from which to assess Hanford Site PCB contamination. Future use of the Aroclor method would continue to provide reliable data for soil, sediment, groundwater, and surface water samples. However, because of the complex matrix found in fish tissue, analysis of PCB congeners would help identify analytical interferences and lead to more reliable results for that matrix.

\subsection{SUMMARY AND CONCLUSIONS}

Hanford Site uses of PCBs were not unlike typical uses of commercial PCB materials that were confined to certain pieces of equipment in closed systems. PCBs were functionally effective materials used in transformers, hydraulic equipment, capacitors, paint, sealants, and light ballasts. Releases to the environment during Hanford operations were from standard disposal practices of the era due to lack of knowledge of the hazards associated with the chemicals. Documented PCB releases and suspected releases on site were investigated and cleaned as needed. PCB releases to soil through road-oiling practices leaves four roadways highly suspected of contamination, 15 as potentially contaminated, and one investigated and confirmed clean.

Environmental transport is dependent on the mixture of PCBs exposed. PCBs most commonly found on site are of the mixtures Aroclor-1254 and 1260, which are the more highly chlorinated PCBs. More chlorinated PCBs have hydrophobic properties and the majority of the congeners present in these mixtures are less volatile. For these reasons the PCBs would more likely adhere to soils and sediment with low potential for transport and migration.

Aquatic studies of PCB contamination in fish and river sediments have been conducted in the Columbia River as well as tributaries upstream of the Hanford Site. The ranging nature of some of the fish studied in the Hanford Reach makes identification of a local source difficult. Levels detected in fish from the Hanford Reach were less than or similar to concentrations found state and nationwide. Hanford Site sediments studied resulted in one single detection of PCBs, compared to upstream Spokane River sediments that showed many detections at much higher levels than that found in the Hanford Reach. Evidence from Spokane River studies indicate contaminant sequestering in sediment loading behind dams (Johnson 2001), making the Spokane River an unlikely source for contamination to the Hanford Site.

Two analytical techniques are used to identify PCBs: Aroclors by SW-846 Method 8082 and congeners by the more sensitive EPA Method 1668A. Because the lower chlorinated congeners volatilize and biodegrade easier it is possible that the loss of those congeners between the time of release and analysis would lead to distorted chromatograms, making Aroclor profile recognition by method 8082 more difficult. Degradation of Aroclors identified at the Hanford Site would be low due to the abundance of highly chlorinated congeners that make up the Hanford Site mixtures. However, difficulties identifying Aroclors in complex environmental samples, such as biological tissues, suggests a need for a more sensitive congener analysis. Congener abundances found in each Aroclor mixture can be found in Appendix E. 
Table 15 summarizes known locations of PCB contamination at the Hanford Site, as well as remaining uninvestigated potential release points. The waste sites listed in the location column are all waste sites with PCB concentrations in soil above the remedial action goal of $500 \mathrm{ppb}$. Additional samples results from these locations can be found in Appendix C. As shown many of these sites have been remediated, with soil excavated to concentrations less than the remedial action goals.

Table 15. Major PCB Source Areas. (2 Pages)

\begin{tabular}{|c|c|c|c|c|c|}
\hline Location & $\begin{array}{l}\text { Nature of } \\
\text { Release }\end{array}$ & $\begin{array}{c}\text { Maximum } \\
\text { Concentration } \\
(\mathrm{ppb})\end{array}$ & Affected Media & $\begin{array}{c}\text { Migration } \\
\text { Pathway }\end{array}$ & $\begin{array}{l}\text { Remedial } \\
\text { Status }\end{array}$ \\
\hline 100-B-1 & Disposal/dumping & 690 & Subsurface soil & Groundwater & Unremediated \\
\hline 100-B-20 & $\begin{array}{l}\text { Underground } \\
\text { liquid release }\end{array}$ & 3400 & Subsurface soil & Groundwater & Remediated \\
\hline $100-D-21$ & Disposal/dumping & 8700 & & & \\
\hline $100-D-22$ & Disposal/dumping & 47000 & Subsurface soil & Groundwater & Remediated \\
\hline $\begin{array}{c}100-F- \\
26: 9 \\
\end{array}$ & $\begin{array}{l}\text { Underground } \\
\text { liquid release }\end{array}$ & 620 & Subsurface soil & Groundwater & Unremediated \\
\hline $100-F-15$ & $\begin{array}{l}\text { Underground } \\
\text { liquid release }\end{array}$ & 720 & Subsurface soil & Groundwater & Unremediated \\
\hline $100-\mathrm{H}-24$ & Substation leak & 2300 & $\begin{array}{l}\text { Surface/subsurface } \\
\text { soil }\end{array}$ & $\begin{array}{c}\text { Surface } \\
\text { water / } \\
\text { groundwater }\end{array}$ & Remediated \\
\hline $\begin{array}{l}\text { 116-DR- } \\
9\end{array}$ & $\begin{array}{l}\text { Solid material } \\
\text { leach to soil }\end{array}$ & 6900 & Subsurface soil & Groundwater & Remediated \\
\hline $116-F-9$ & Disposal/dumping & 4300 & Subsurface soil & Groundwater & Remediated \\
\hline $116-\mathrm{H}-5$ & $\begin{array}{l}\text { Underground } \\
\text { liquid release }\end{array}$ & 7400 & Subsurface soil & Groundwater & Unremediated \\
\hline $116-\mathrm{H}-7$ & $\begin{array}{l}\text { Solid material } \\
\text { leach to soil }\end{array}$ & 64000 & Subsurface soil & Groundwater & Remediated \\
\hline $\begin{array}{c}\text { 118-DR- } \\
2: 2 \\
\end{array}$ & $\begin{array}{l}\text { Underground } \\
\text { liquid release }\end{array}$ & 2065 & Subsurface soil & Groundwater & Remediated \\
\hline $\begin{array}{l}118-\mathrm{F}- \\
8: 1\end{array}$ & $\begin{array}{l}\text { Underground } \\
\text { liquid release }\end{array}$ & 62000 & Subsurface soil & Groundwater & Unremediated \\
\hline 120-B-1 & $\begin{array}{l}\text { Underground } \\
\text { liquid release }\end{array}$ & 3600 & Subsurface soil & Groundwater & Unremediated \\
\hline 120-D-1 & Disposal/dumping & 17000 & Subsurface soil & Groundwater & Remediated \\
\hline $128-C-1$ & Disposal/dumping & 540 & Subsurface soil & Groundwater & Remediated \\
\hline 128-F-2 & Disposal/dumping & 940 & Subsurface soil & Groundwater & Un-remediated \\
\hline 1607-D2 & $\begin{array}{l}\text { Underground } \\
\text { liquid release }\end{array}$ & 22000 & Subsurface soil & Groundwater & Remediated \\
\hline 1607-F6 & $\begin{array}{l}\text { Underground } \\
\text { liquid release }\end{array}$ & 53476 & Subsurface soil & Groundwater & Remediated \\
\hline $316-1$ & $\begin{array}{l}\text { Underground } \\
\text { liquid release }\end{array}$ & 3000 & Subsurface soil & Groundwater & Remediated \\
\hline
\end{tabular}


Table 15. Major PCB Source Areas. (2 Pages)

\begin{tabular}{|c|l|c|l|l|c|}
\hline Location & \multicolumn{1}{|c|}{$\begin{array}{c}\text { Nature of } \\
\text { Release }\end{array}$} & $\begin{array}{c}\text { Maximum } \\
\text { Concentration } \\
\text { (ppb) }\end{array}$ & Affected Media & $\begin{array}{c}\text { Migration } \\
\text { Pathway }\end{array}$ & $\begin{array}{c}\text { Remedial } \\
\text { Status }\end{array}$ \\
\hline $316-5$ & $\begin{array}{l}\text { Underground } \\
\text { liquid release }\end{array}$ & 2800 & Subsurface soil & Groundwater & Remediated \\
\hline $600-23$ & Disposal/dumping & 4700 & Subsurface soil & Groundwater & Remediated \\
\hline $618-4$ & Disposal/dumping & 1600 & Subsurface soil & Groundwater & Remediated \\
\hline $618-5$ & Disposal/dumping & 1115 & Subsurface soil & Groundwater & Remediated \\
\hline $618-9$ & Disposal/dumping & 3900 & Subsurface soil & Groundwater & Remediated \\
\hline $\begin{array}{c}100 / 300 \\
\text { Area } \\
\text { oiled } \\
\text { roads }\end{array}$ & Disposal/dumping & NA & Surface/subsurface & $\begin{array}{l}\text { Surface } \\
\text { water / } \\
\text { groundwater }\end{array}$ & Uninvestigated \\
\hline
\end{tabular}

$\mathrm{NA}=\mathrm{PCBs}$ have not been analyzed at this site

Hanford Site characterization efforts have provided adequate information to confirm that there is contamination from historic use of PCBs at the Hanford Site. Groundwater, sediment, and soil data indicate that the contamination is confined to inland soils and no major transport mechanisms are effecting migration. Remedial efforts have shown effective removal of contaminated soils to levels that remain protective of groundwater and human health.

\subsection{REFERENCES}

40 CFR 131, "Water Quality Standards," Code of Federal Regulations, as amended.

40 CFR 761, "Polychlorinated Biphenyls (PCBs) Manufacturing, Processing, Distribution in Commerce, and Use Prohibitions," Code of Federal Regulations, as amended.

BHI, 1997, Potential PCB Contamination of N Basin Hardware Waste, CCN 051650, Bechtel Hanford, Inc., Richland, Washington.

BHI, 1998, PCB Status of N Reactor Fuel to be Transferred to the 327 Facility, CCN 054571, Bechtel Hanford, Inc., Richland, Washington.

BHI, 2001, Management of Demolition Waste Coated with Paints Containing Polychlorinated Biphenyls (PCBs), Reactor Interim Safe Storage (ISS) Project, CCN 086118 to R. Bond and D. A. Faulk from R. R. Nielson, Bechtel Hanford, Inc., Richland, Washington.

Comprehensive Environmental Response, Compensation, and Liability Act of 1980, 42 U.S.C. 9601, et seq.

CVP-98-00001, 1998, Cleanup Verification Package for the 100-D-22 Sludge Pit, Rev. 0, Bechtel Hanford, Inc, Richland, Washington. 
CVP-2001-00020, 2001, Cleanup Verification Package for the 600-23 Dumping Area, Rev. 0, Bechtel Hanford, Inc, Richland, Washington.

CVP-2000-00030, 2001, Cleanup Verification Package for the 100-H-24 Substation, Bechtel Hanford, Inc, Richland, Washington.

Deatherage, R. D., 1995, Response to Environmental Compliance Review, CCN 009402 dated January 23, 1995, to G. S. Robinson, Bechtel Hanford, Inc., Richland, Washington.

DOE/RL-91-58, 1992, Z-Plant Source Aggregate Area Management Study Report, Rev. 0, U.S. Department of Energy, Richland Operations Office, Richland, Washington.

DOE/RL-91-60, 1992, S-Plant Aggregate Area Management Study Report, Rev. 0, U.S. Department of Energy, Richland Operations Office, Richland, Washington.

DOE/RL-91-61, 1992, T-Plant Aggregate Area Management Study Report, Rev. 0, U.S. Department of Energy, Richland Operations Office, Richland, Washington.

DOE/RL-92-05, 1993, B-Plant Source Aggregate Area Management Study Report, Rev. 0, U.S. Department of Energy, Richland Operations Office, Richland, Washington.

DOE/RL-2001-50, 2003, Toxic Substances Control Act Polychlorinated Biphenyls Hanford Site Users Guide, Rev. 1, U.S. Department of Energy, Richland Operations Office, Richland, Washington.

DOE/RL-2006-42, 2006, 2005 Polychlorinated Biphenyl Annual Log, Rev. 0, U.S. Department of Energy, Richland Operations Office, Richland, Washington.

DOE/RL-2007-21, 2007, Risk Assessment Report for the 100 Area and 300 Area Component of the RCBRA, Draft A, U.S. Department of Energy, Richland Operations Office, Richland, Washington.

Ecology, EPA, and DOE, 2000, Framework Agreement for Management of Polychlorinated Biphenyls (PCBS) in Hanford Tank Waste, August 31, Washington State Department of Ecology, U.S. Environmental Protection Agency, U.S. Department of Energy , Richland, Washington.

Eisler, R., 1986, Polychlorinated Biphenyl Hazards to Fish, Wildlife, and Invertebrates: A Synoptic Review, Biological Report 85(1.7), U.S. Fish and Wildlife Service, Laurel, Maryland.

EPA, 2002, Columbia River Basin Fish Contaminant Survey 1996-1998, EPA 910-R-02-006, U.S. Environmental Protection Agency Region 10, Seattle, Washington.

Fickeisen, D. H., D. D. Dauble, D. A. Neitzel, W. H. Rickard, R. L. Skaggs, and J. L. Warren, 1980, Aquatic and Riparian Resource Study of the Hanford Reach, Columbia River, Washington, Pacific Northwest Laboratory, Richland, Washington.

Frame, J., 1996, Journal of High Resolution Chromatography Vol.19, p 657-668. 
Golding, S., 2002, Spokane Area Point Source PCB Survey May 2001, 98504-7710, Washington State Department of Ecology Environmental Assessment Program, Olympia, Washington.

Johnson, A., 2001, An Ecological Hazard Assessment for PCBs in the Spokane River, 01-03015, Washington State Department of Ecology, Olympia, Washington.

Patton, G.W., personal phone interview 7 May 2007.

Peterschmidt, M., 2004, Lower Okanogan River Basin DDT and PCBs Total Maximum Daily Load, 04-10-043, Washington State Department of Ecology Water Quality Program, Olympia, Washington.

Perry, J. A., 1979, Archives of Environmental Contamination and Toxicology (Pesticide and PCB Residues in the Upper Snake River Ecosystem, Southeastern Idaho, Following the Collapse of the Teton Dam 1976), Springer-Verlag New York Inc., New York.

PNL-5625, 1986, Distribution of Polychlorinated Biphenyls (PCBs) in Surface Sediments of Gable Mountain Pond, Pacific Northwest Laboratory, Richland, Washington.

PNL-5685, 1986, A Preliminary Survey of Polychlorinated Biphenyls (PCBs) in Aquatic Habitats and Great Blue Herons on the Hanford Site, Pacific Northwest Laboratory, Richland, Washington.

PNL-6795, 1988, Assessment of Aquatic Organisms as Bioindicators of Historical Radionuclide Release to the Columbia River, Pacific Northwest Laboratories, Richland, Washington.

PNL-8479, 1992, Snake and Columbia Rivers Sediment Sampling Project, Pacific Northwest National Laboratory, Richland, Washington.

PNL-10535, 1995, Environmental Monitoring of Columbia River Sediments: Grain-Size Distribution and Contamination Associated, Pacific Northwest Laboratory, Richland, Washington.

PNNL-11651, 1997, Investigation of Potential Polychlorinated Biphenyl (PCB) Contamination on Hanford Site Arc-Loop Roads, Pacific Northwest National Laboratory, Richland, Washington.

Riley, R. G., 1984, CCN-134262, Washington Closure Hanford, Richland, Washington.

Riley, R. G., personal interview, June 6, 2007.

RHO, 1984, EPA PCB Inspection Report and Notice of Noncompliance, letter to U.S. Department of Energy from B. E. Knight, Rockwell Hanford Operations, Richland, Washington.

RPP-6693a, 2002, Fiscal Year 2003 PCB Characterization Plan for Tank Farm Waste, Rev. 3, $\mathrm{CH} 2 \mathrm{MHill}$ Hanford Group, Inc. Richland, Washington.

RPP-6993b, 2003, Fiscal Year 2004 PCB Characterization Plan for Tank Farm Waste, Rev. 4, $\mathrm{CH} 2 \mathrm{MHill}$ Hanford Group, Inc. Richland, Washington. 
Seidars, K., C. Deligeannis, and K. Kinney, 2006, Washington State Toxics Monitoring Program Toxic Contaminants in Fish Tissue and Surface Water in Freshwater Environments, 2003, 06-03-019, Washington State Department of Ecology, Olympia, Washington.

Serdar, D. and A. Johnson, 2006, PCBs, PBDEs, and Selected Metals in Spokane River Fish, 2005, Publication No. 06-03-025, Washington State Department of Ecology, Olympia, Washington.

Shiu, W. Y. and D. J. Mackay, 1986, Phys. Chem. Ref Data,15(2):911-929.

Stankovich, M. T., 1991, 100-H \& 100-B Electrical Facilities Source Sampling, WCH-SD-EN-AP-064, Westinghouse Hanford, Richland, Washington.

Toxic Substances Control Act, 15 U.S.C. 2601, et seq.

USDHHS, 2000, Toxicological Profile for Polychlorinated Biphenyls (PCBs), Agency for Toxic Substances Disease Registry.

Washington State Department of Ecology, NPDES, http://www.ecy.wa.gov/programs/wq/permits/\#wastewater_individual_permits 


\section{APPENDIX A}

FIGURES OF 100 AND 300 AREAS OILED ROADS 
WCH-208

Rev. 0 

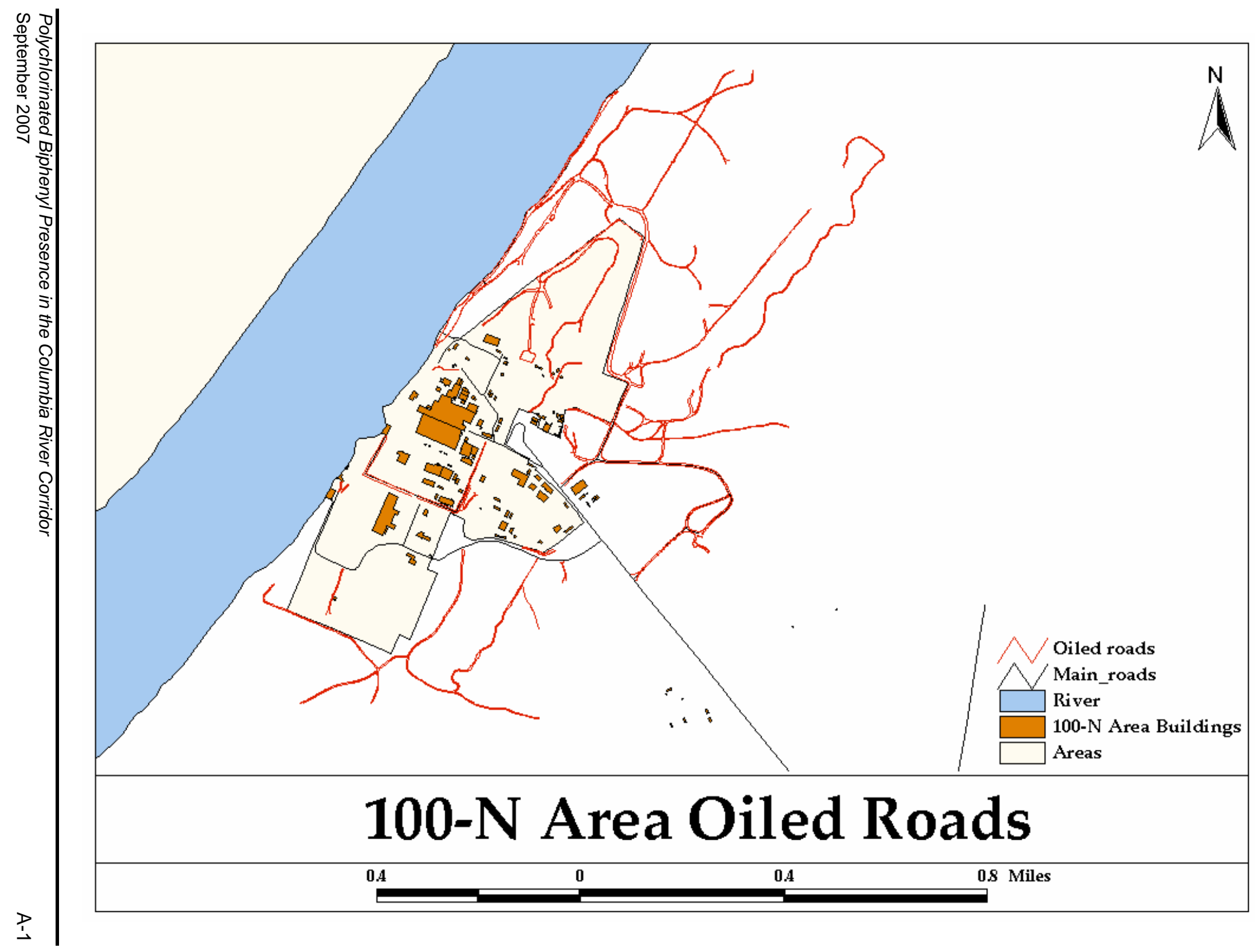

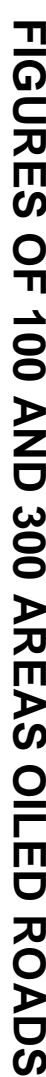

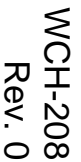




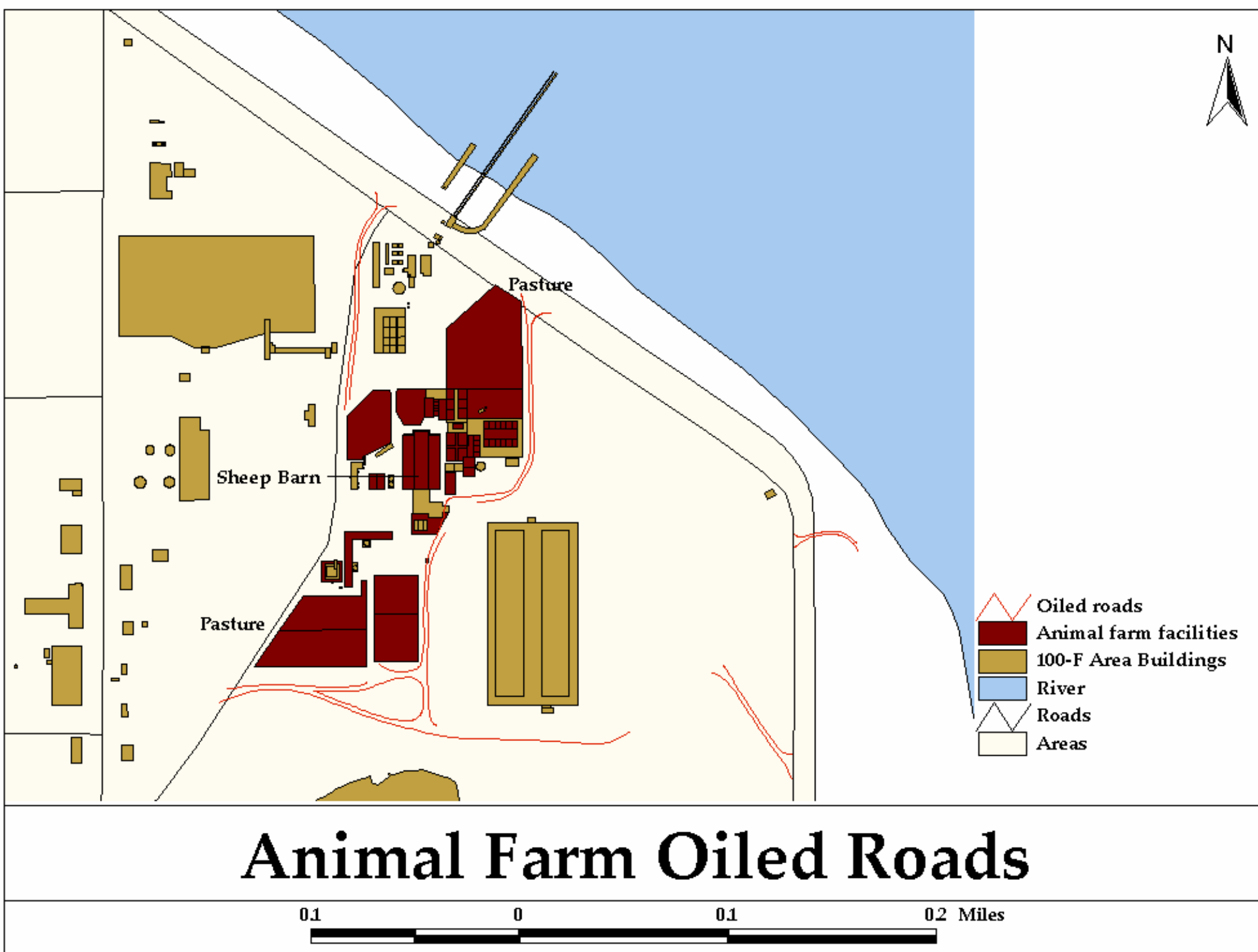




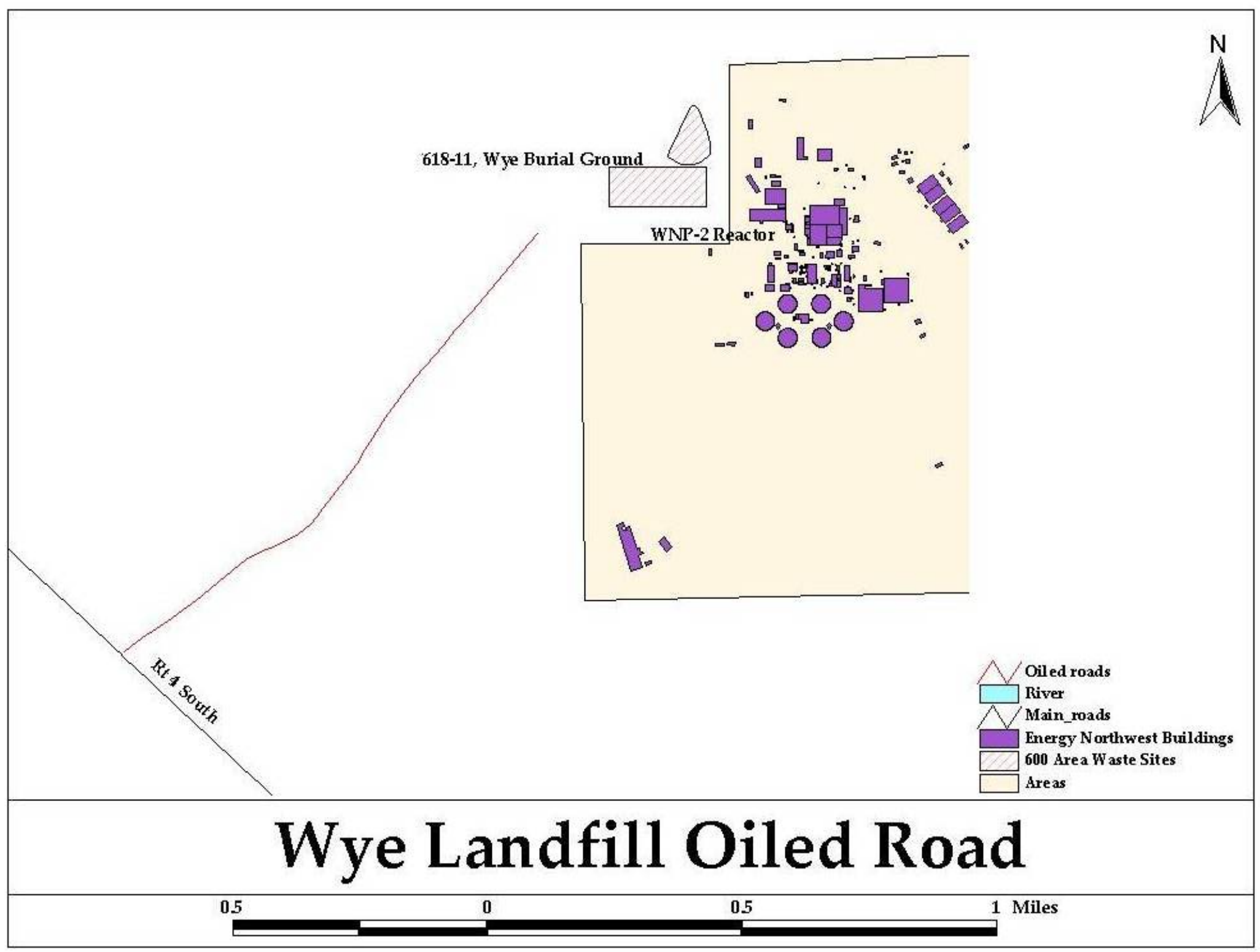




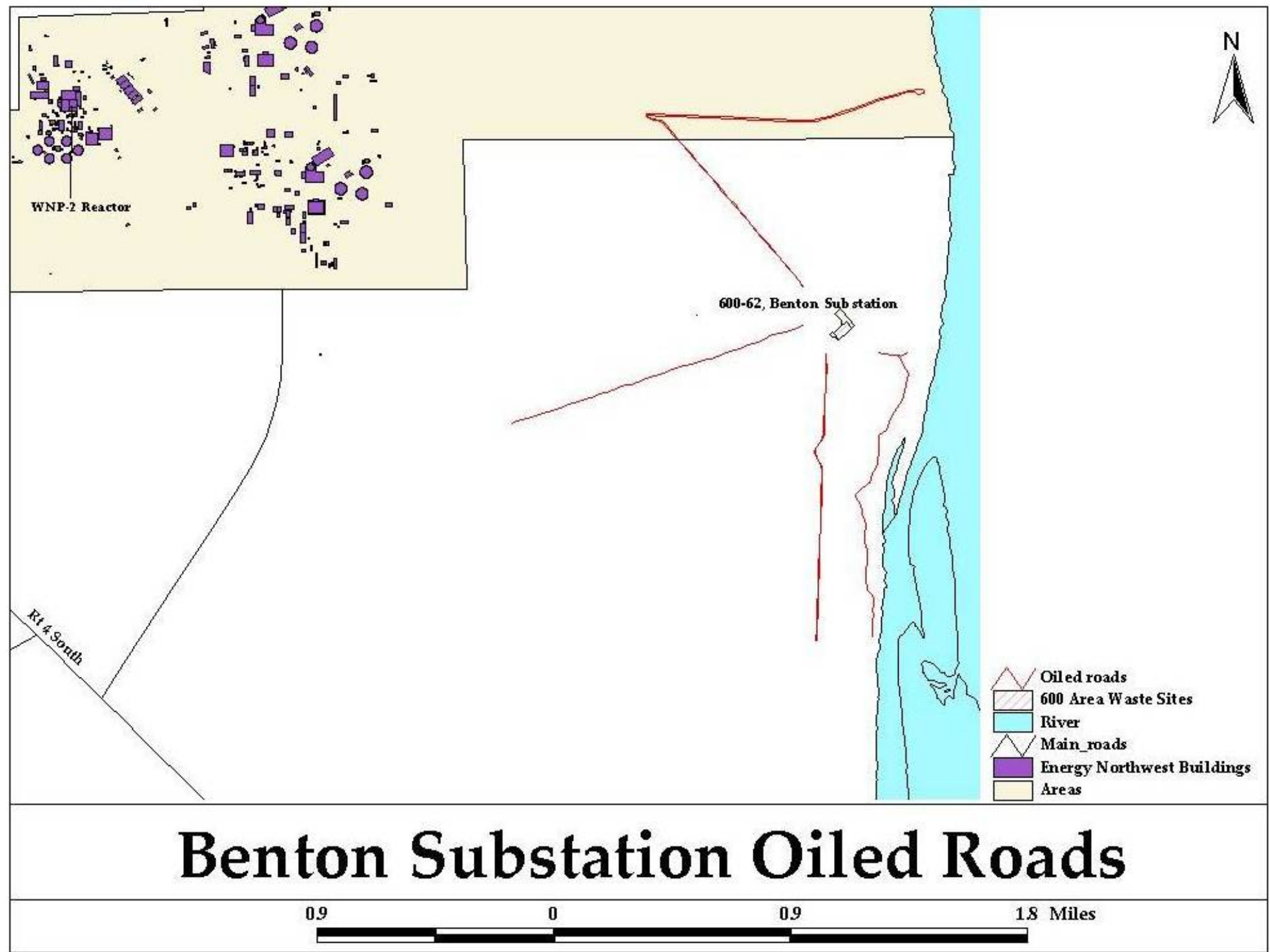




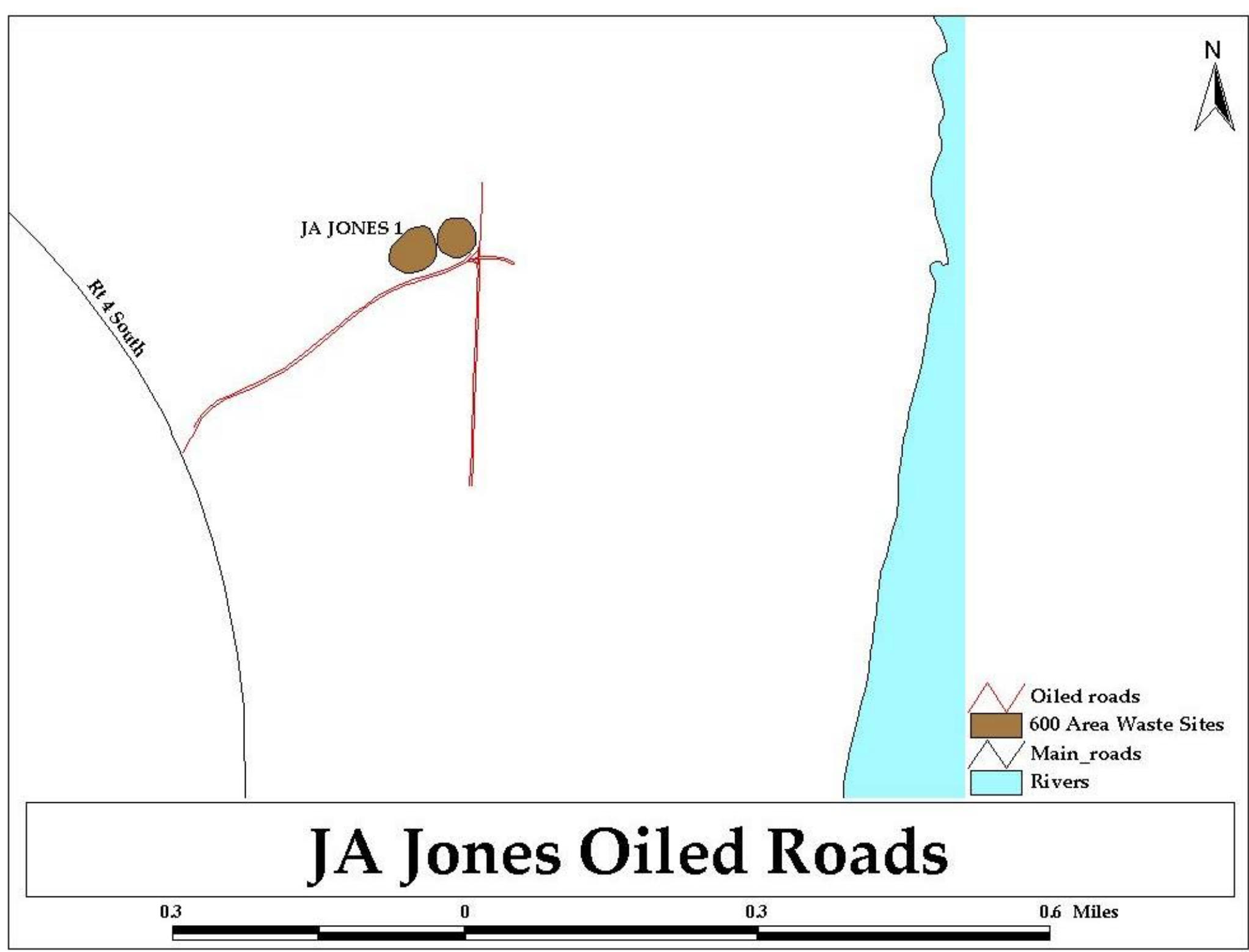




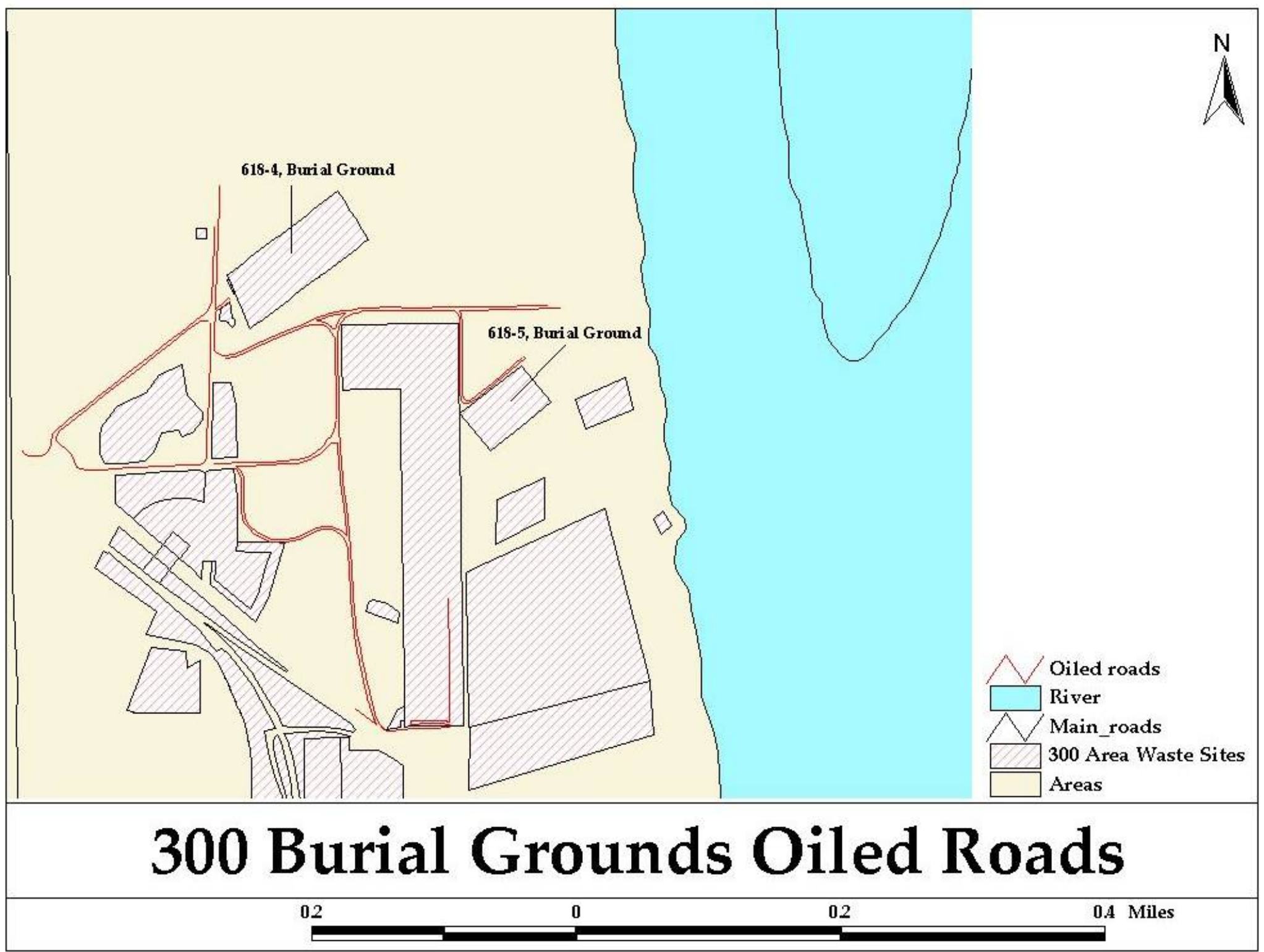




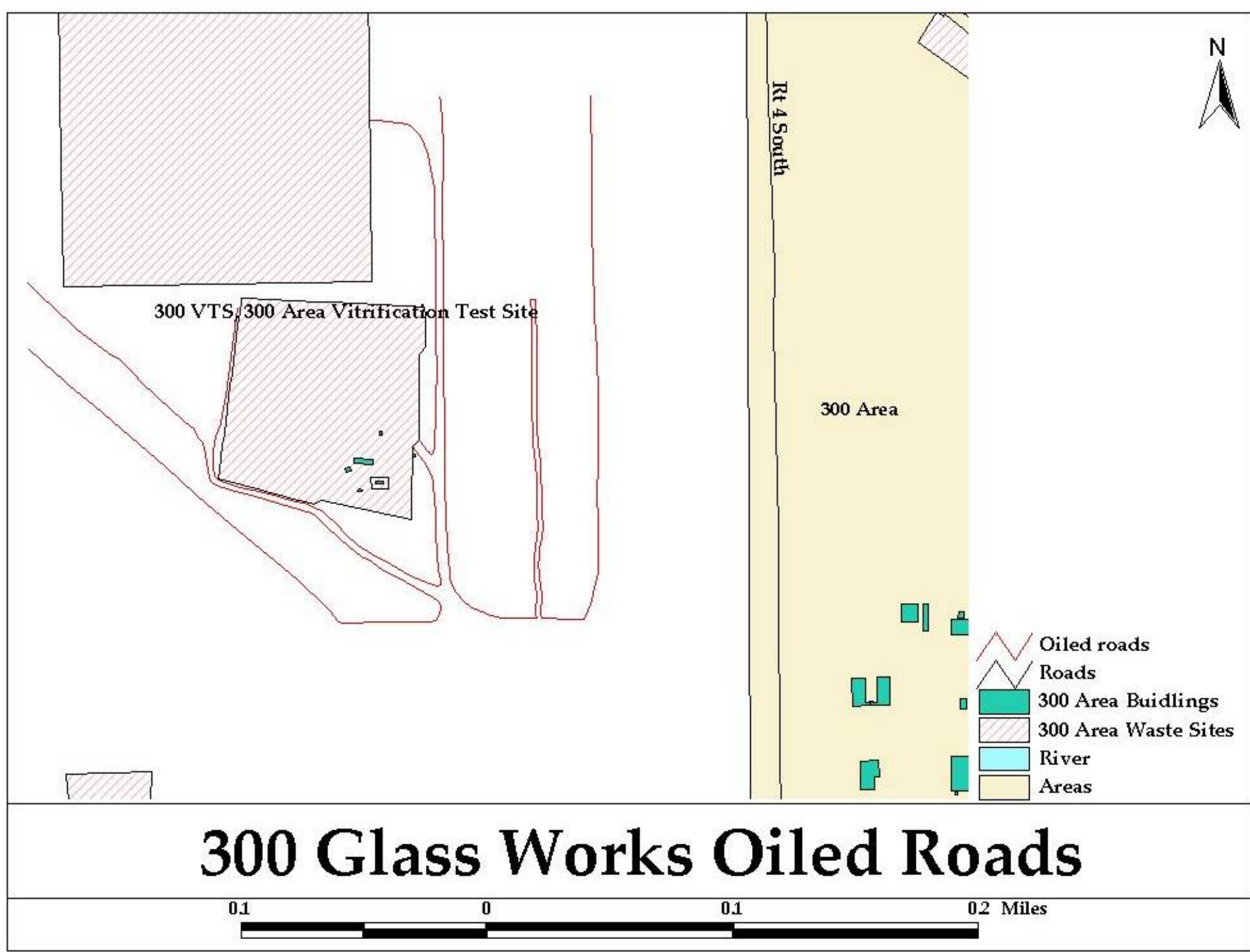




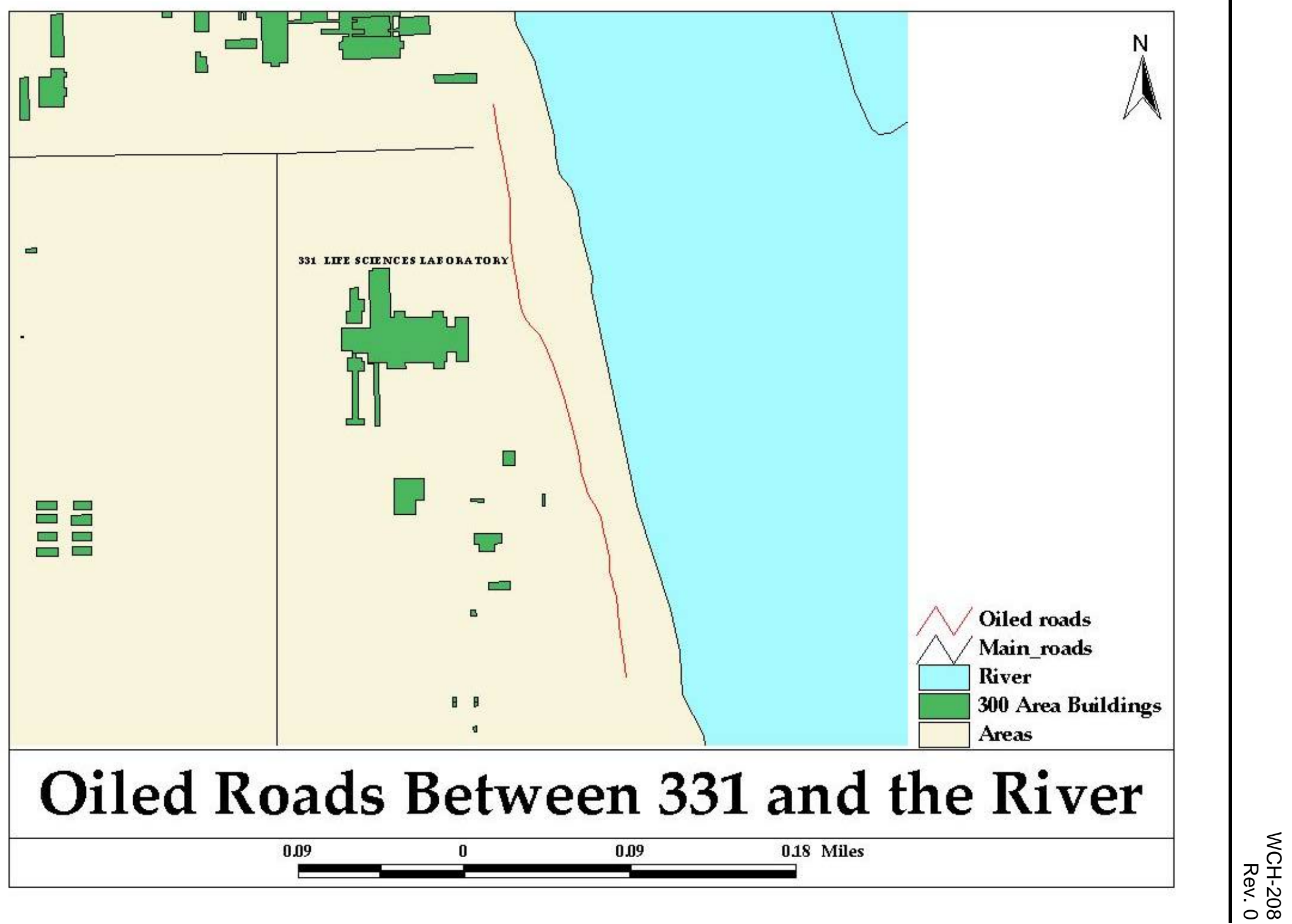




\section{APPENDIX B}

\section{FIGURES OF 100 AND 300 AREAS PCBS IN SOIL}


WCH-208

Rev. 0 


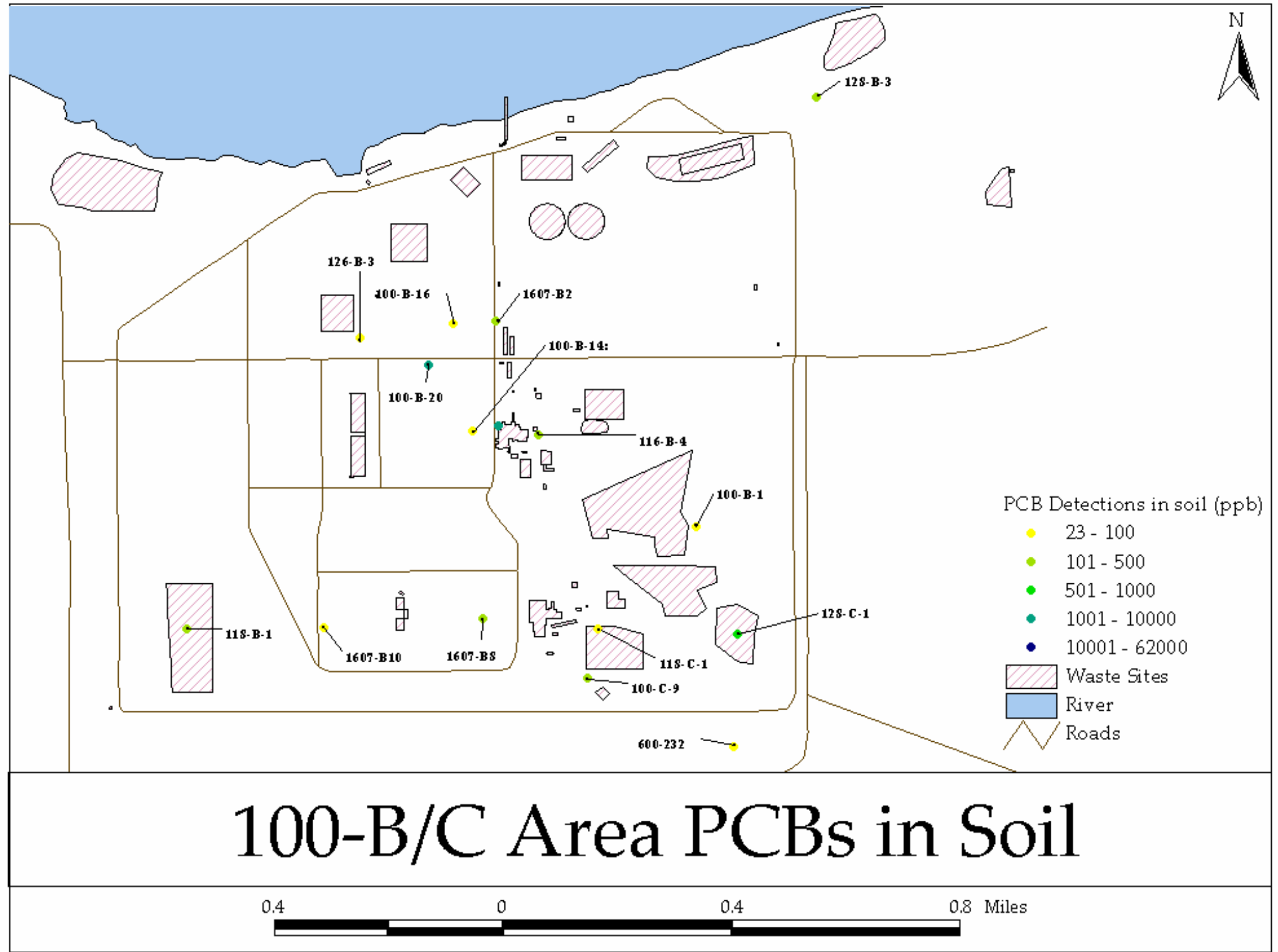

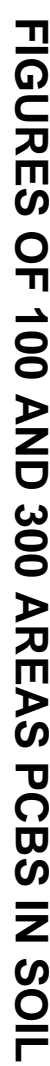

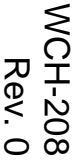




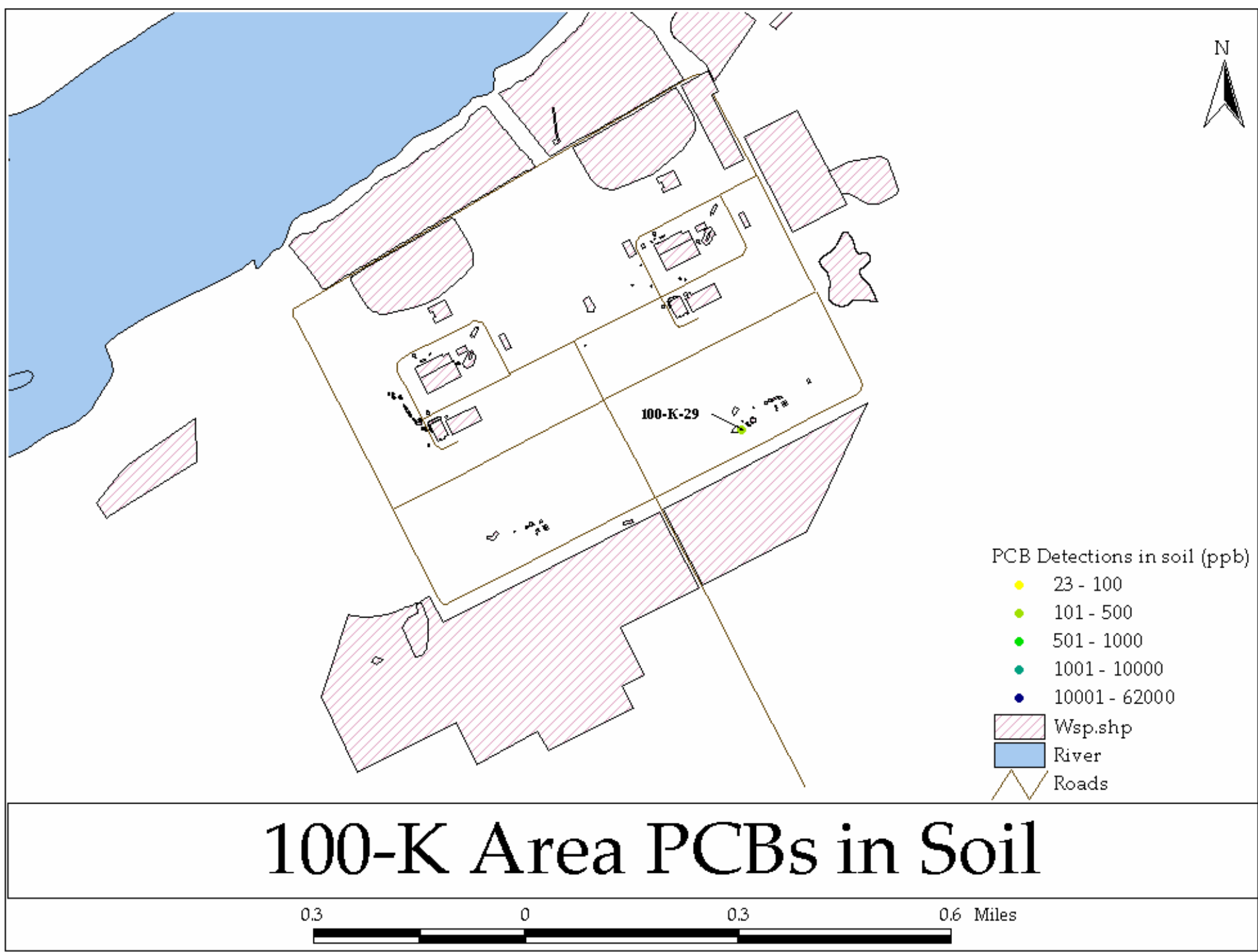




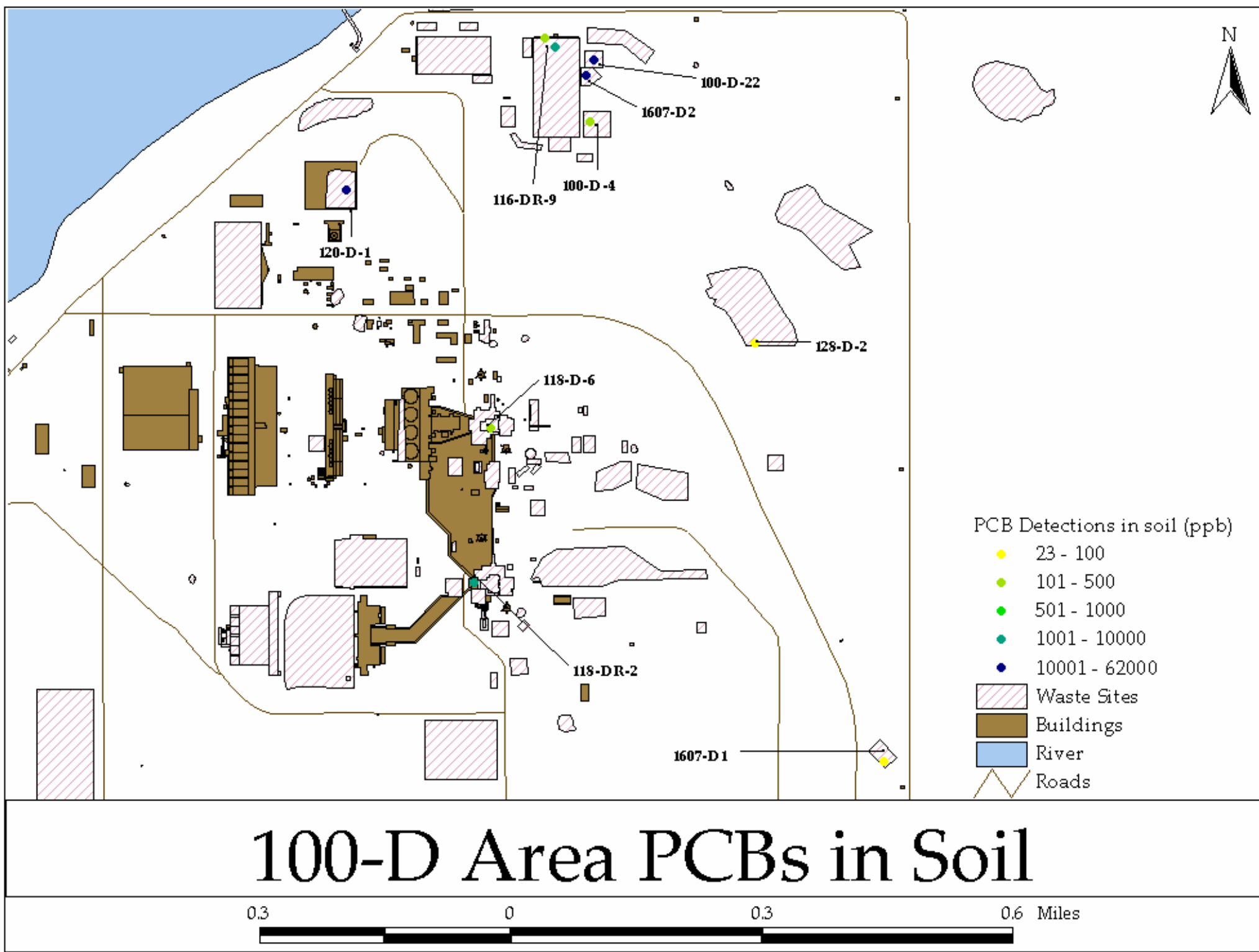

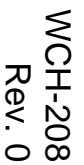




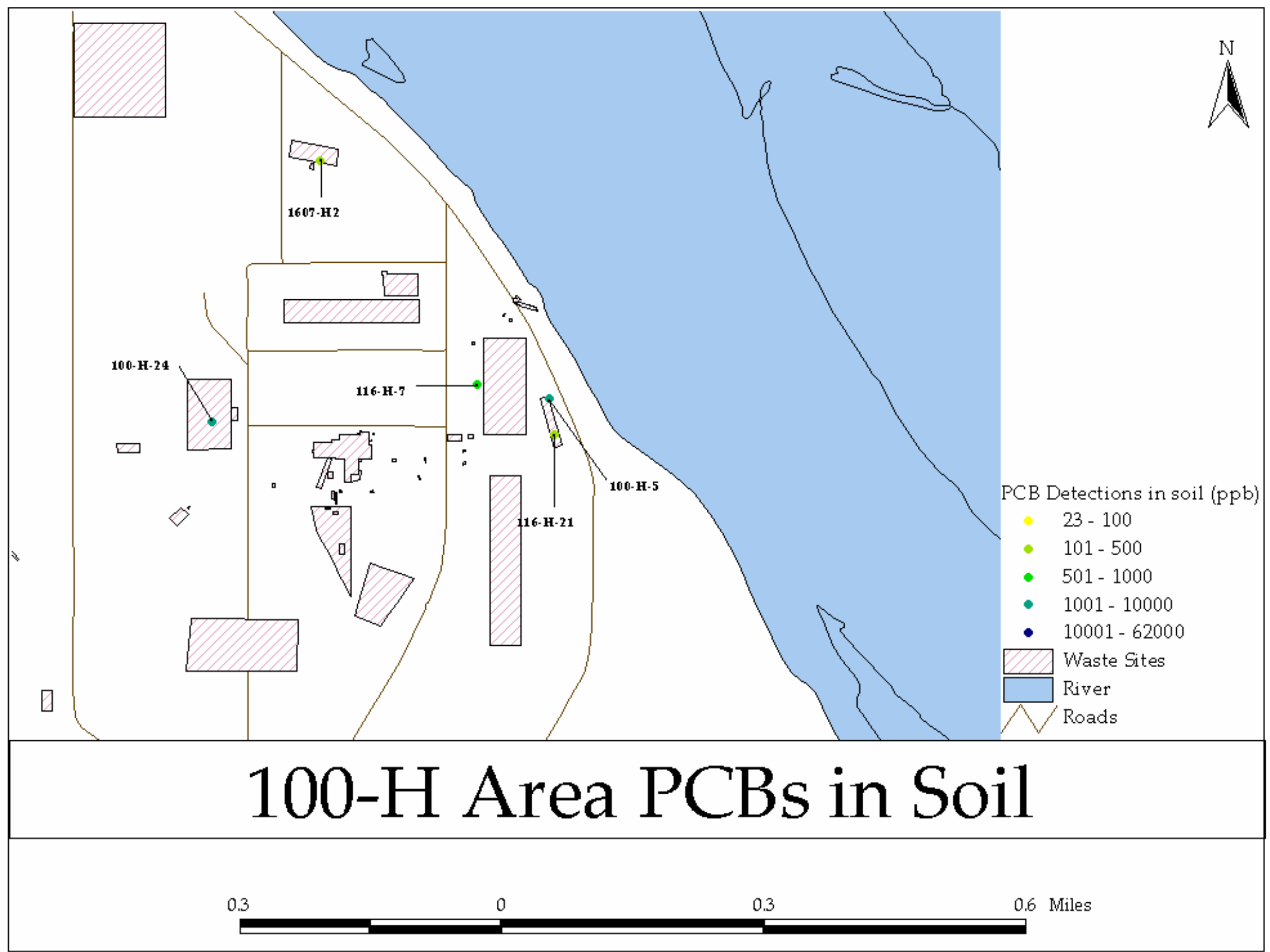

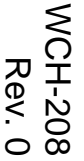




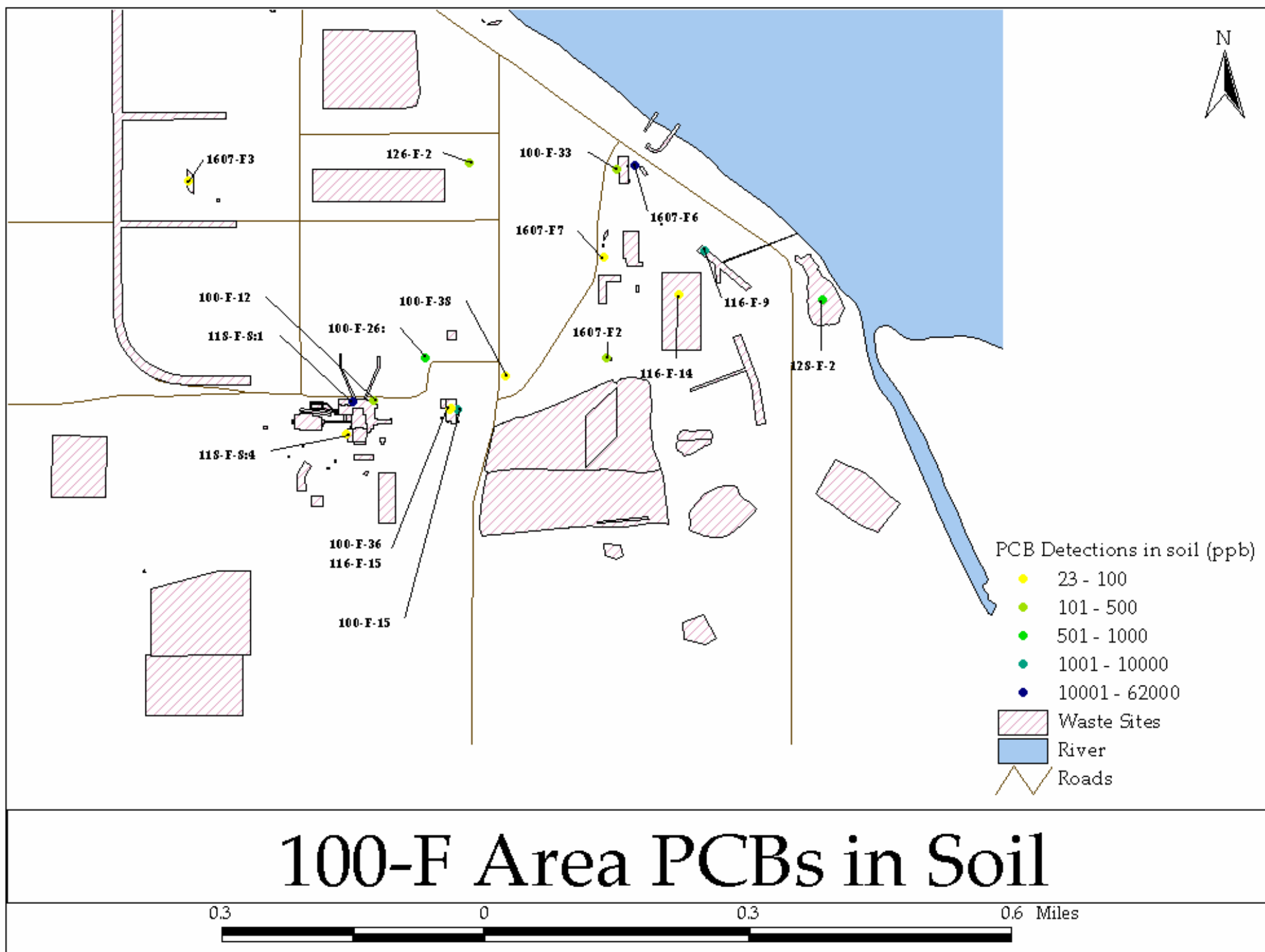

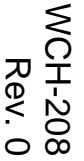




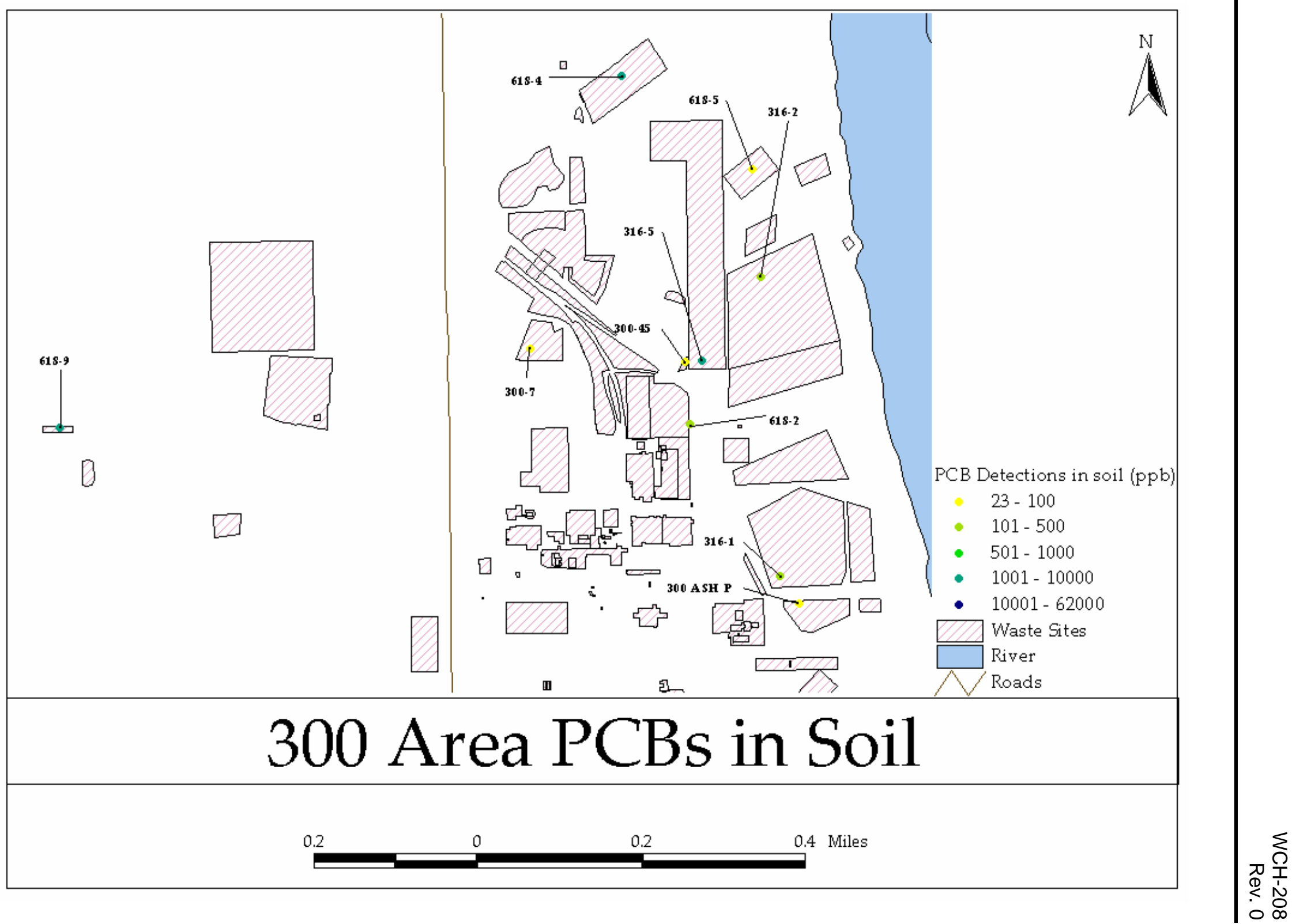




\section{APPENDIX C}

\section{DATA TABLES FOR 100 AND 300 AREAS PCBS IN SOIL}


WCH-208

Rev. 0 


\section{APPENDIX C}

\section{DATA TABLES FOR 100 AND 300 AREAS PCBS IN SOIL}

\begin{tabular}{|c|c|c|c|c|c|c|}
\hline Aroclor & $\begin{array}{l}\text { Sample } \\
\text { Date }\end{array}$ & $\begin{array}{l}\text { Sample } \\
\text { Number }\end{array}$ & Result & Units & Well Name & $\begin{array}{c}\text { Waste Site or } \\
\text { Well ID }\end{array}$ \\
\hline Aroclor-1254 & 18-Apr-07 & J134V7 & 52 & $\mathrm{ug} / \mathrm{kg}$ & & 331 \\
\hline Aroclor-1254 & 18-Apr-07 & J134V6 & 56 & $\mathrm{ug} / \mathrm{kg}$ & & 331 \\
\hline Aroclor-1254 & 19-Apr-07 & J134V8 & 140 & $\mathrm{ug} / \mathrm{kg}$ & & 331 \\
\hline Aroclor-1254 & 22-Aug-05 & J03X39 & 14 & $\mathrm{ug} / \mathrm{kg}$ & & $100-B-1$ \\
\hline Aroclor-1254 & 22-Aug-05 & J03X26 & 20 & $\mathrm{ug} / \mathrm{kg}$ & & 100-B-1 \\
\hline Aroclor-1254 & 22-Aug-05 & J03X29 & 33 & $\mathrm{ug} / \mathrm{kg}$ & & 100-B-1 \\
\hline Aroclor-1254 & 22-Aug-05 & J03X31 & 35 & $\mathrm{ug} / \mathrm{kg}$ & & 100-B-1 \\
\hline Aroclor-1242 & 14-Apr-92 & B05XZ5 & 37 & $\mathrm{ug} / \mathrm{kg}$ & & $100-B-1$ \\
\hline Aroclor-1248 & 14-Apr-92 & B05XZ5 & 37 & $\mathrm{ug} / \mathrm{kg}$ & & 100-B-1 \\
\hline Aroclor-1254 & 14-Apr-92 & B05XZ5 & 37 & $\mathrm{ug} / \mathrm{kg}$ & & 100-B-1 \\
\hline Aroclor-1260 & 14-Apr-92 & B05XZ5 & 37 & $\mathrm{ug} / \mathrm{kg}$ & & 100-B-1 \\
\hline Aroclor-1232 & 14-Apr-92 & B05XZ4 & 35 & $\mathrm{ug} / \mathrm{kg}$ & & 100-B-1 \\
\hline Aroclor-1242 & 14-Apr-92 & B05XZ4 & 35 & $\mathrm{ug} / \mathrm{kg}$ & & $100-B-1$ \\
\hline Aroclor-1254 & 14-Apr-92 & B05XZ4 & 35 & $\mathrm{ug} / \mathrm{kg}$ & & $100-B-1$ \\
\hline Aroclor-1260 & 14-Apr-92 & B05XZ4 & 35 & $\mathrm{ug} / \mathrm{kg}$ & & 100-B-1 \\
\hline Aroclor-1016 & 14-Apr-92 & B05XZ5 & 37 & $\mathrm{ug} / \mathrm{kg}$ & & 100-B-1 \\
\hline Aroclor-1232 & 14-Apr-92 & B05XZ5 & 37 & $\mathrm{ug} / \mathrm{kg}$ & & $100-B-1$ \\
\hline Aroclor-1221 & 14-Apr-92 & B05XZ4 & 72 & $\mathrm{ug} / \mathrm{kg}$ & & $100-B-1$ \\
\hline Aroclor-1221 & 14-Apr-92 & B05XZ5 & 74 & $\mathrm{ug} / \mathrm{kg}$ & & 100-B-1 \\
\hline Aroclor-1254 & 09-Dec-91 & B018R7 & 390 & $\mathrm{ug} / \mathrm{kg}$ & & 100-B-1 \\
\hline Aroclor-1260 & 18-Jul-95 & B0G8R5 & 690 & $\mathrm{ug} / \mathrm{kg}$ & & 100-B-1 \\
\hline Aroclor-1254 & 18-Jul-95 & B0G8R5 & 2700 & $\mathrm{ug} / \mathrm{kg}$ & & 100-B-1 \\
\hline Aroclor-1260 & 18-Sep-03 & J00Y85 & 16 & $\mathrm{ug} / \mathrm{kg}$ & & 100-B-14 \\
\hline Aroclor-1260 & 06-Oct-03 & J0OYN9 & 35 & $\mathrm{ug} / \mathrm{kg}$ & & 100-B-14:3 \\
\hline Aroclor-1254 & 06-Jul-06 & J12R05 & 14 & $\mathrm{ug} / \mathrm{kg}$ & & 100-B-14:8 \\
\hline Aroclor-1254 & 06-Jul-06 & J12R13 & 15 & $\mathrm{ug} / \mathrm{kg}$ & & 100-B-14:8 \\
\hline Aroclor-1254 & 06-Jul-06 & J12R09 & 63 & $\mathrm{ug} / \mathrm{kg}$ & & 100-B-14:8 \\
\hline Aroclor-1254 & 06-Jul-06 & J12R14 & 78 & $\mathrm{ug} / \mathrm{kg}$ & & 100-B-14:8 \\
\hline Aroclor-1254 & 06-Jul-06 & J12R07 & 84 & $\mathrm{ug} / \mathrm{kg}$ & & 100-B-14:8 \\
\hline Aroclor-1254 & 06-Jul-06 & J12R06 & 95 & $\mathrm{ug} / \mathrm{kg}$ & & 100-B-14:8 \\
\hline Aroclor-1260 & 25-Jan-05 & J02FM0 & 24 & $\mathrm{ug} / \mathrm{kg}$ & & 100-B-16 \\
\hline Aroclor-1260 & 27-Jun-07 & J156F8 & 26 & $\mathrm{ug} / \mathrm{kg}$ & & $100-B-18$ \\
\hline
\end{tabular}




\begin{tabular}{|c|c|c|c|c|c|c|}
\hline Aroclor & $\begin{array}{l}\text { Sample } \\
\text { Date }\end{array}$ & $\begin{array}{l}\text { Sample } \\
\text { Number }\end{array}$ & Result & Units & Well Name & $\begin{array}{l}\text { Waste Site or } \\
\text { Well ID }\end{array}$ \\
\hline Aroclor-1260 & 27-Jun-07 & J156F9 & 95 & $\mathrm{ug} / \mathrm{kg}$ & & 100-B-19 \\
\hline Aroclor-1254 & 18-Jan-06 & J10V68 & 3400 & ug/kg & & $100-B-20$ \\
\hline Aroclor-1016 & 14-Apr-92 & B05XZ4 & 35 & $\mathrm{ug} / \mathrm{kg}$ & & $100-B-1$ \\
\hline Aroclor-1254 & 21-Mar-05 & J030B4 & 43 & $\mathrm{ug} / \mathrm{kg}$ & & 100-C-7 \\
\hline Aroclor-1254 & 17-Mar-05 & J03065 & 52 & $\mathrm{ug} / \mathrm{kg}$ & & $100-C-7$ \\
\hline Aroclor-1254 & 17-Sep-03 & J00YB3 & 110 & $\mathrm{ug} / \mathrm{kg}$ & & $100-C-9$ \\
\hline Aroclor-1254 & 17-Sep-03 & J00YB4 & 170 & $\mathrm{ug} / \mathrm{kg}$ & & $100-C-9$ \\
\hline Aroclor-1254 & 07-Sep-06 & J135M3 & 15 & $\mathrm{ug} / \mathrm{kg}$ & & 100-C-9:2 \\
\hline Aroclor-1254 & 05-Apr-06 & J11VL6 & 20 & $\mathrm{ug} / \mathrm{kg}$ & & 100-C-9:2 \\
\hline Aroclor-1254 & 05-Apr-06 & J11VL8 & 27 & $\mathrm{ug} / \mathrm{kg}$ & & 100-C-9:2 \\
\hline Aroclor-1254 & 05-Apr-06 & J11VM1 & 39 & $\mathrm{ug} / \mathrm{kg}$ & & 100-C-9:2 \\
\hline Aroclor-1254 & 05-Apr-06 & J11VL1 & 40 & $\mathrm{ug} / \mathrm{kg}$ & & 100-C-9:2 \\
\hline Aroclor-1254 & 05-Apr-06 & J11VM3 & 100 & $\mathrm{ug} / \mathrm{kg}$ & & 100-C-9:2 \\
\hline Aroclor-1254 & 05-Apr-06 & J11VM5 & 120 & $\mathrm{ug} / \mathrm{kg}$ & & 100-C-9:2 \\
\hline Aroclor-1242 & 29-Jul-97 & BOK0F6 & 69 & $\mathrm{ug} / \mathrm{kg}$ & & $100-D-22$ \\
\hline Aroclor-1242 & 29-Jul-97 & BOK0F6 & 69 & $\mathrm{ug} / \mathrm{kg}$ & & $100-D-22$ \\
\hline Aroclor-1260 & 27-Jan-98 & BONOM3 & 8700 & $\mathrm{ug} / \mathrm{kg}$ & & 100-D-21 \\
\hline Aroclor-1242 & 29-Jul-97 & BOK0F6 & 69 & $\mathrm{ug} / \mathrm{kg}$ & & $100-D-22$ \\
\hline Aroclor-1242 & 29-Jul-97 & BOK0F6 & 69 & $\mathrm{ug} / \mathrm{kg}$ & & 100-D-22 \\
\hline Aroclor-1242 & 29-Jul-97 & BOK0F6 & 69 & $\mathrm{ug} / \mathrm{kg}$ & & $100-D-22$ \\
\hline Aroclor-1242 & 29-Jul-97 & B0K0F5 & 130 & $\mathrm{ug} / \mathrm{kg}$ & & $100-D-22$ \\
\hline Aroclor-1242 & 29-Jul-97 & B0K0F5 & 130 & ug/kg & & $100-D-22$ \\
\hline Aroclor-1242 & 29-Jul-97 & BOK0F5 & 130 & $\mathrm{ug} / \mathrm{kg}$ & & 100-D-22 \\
\hline Aroclor-1242 & 29-Jul-97 & BOK0F5 & 130 & $\mathrm{ug} / \mathrm{kg}$ & & 100-D-22 \\
\hline Aroclor-1242 & 29-Jul-97 & B0K0F5 & 130 & $\mathrm{ug} / \mathrm{kg}$ & & $100-D-22$ \\
\hline Aroclor-1242 & 29-Jul-97 & BOKOF9 & 220 & ug/kg & & $100-D-22$ \\
\hline Aroclor-1242 & 29-Jul-97 & BOKOF9 & 220 & ug/kg & & $100-D-22$ \\
\hline Aroclor-1242 & 29-Jul-97 & BOKOF9 & 220 & $\mathrm{ug} / \mathrm{kg}$ & & 100-D-22 \\
\hline Aroclor-1242 & 29-Jul-97 & BOKOF9 & 220 & $\mathrm{ug} / \mathrm{kg}$ & & $100-D-22$ \\
\hline Aroclor-1242 & 29-Jul-97 & BOKOF9 & 220 & $\mathrm{ug} / \mathrm{kg}$ & & $100-D-22$ \\
\hline Aroclor-1260 & 29-Jul-97 & BOKOF6 & 330 & $\mathrm{ug} / \mathrm{kg}$ & & 100-D-22 \\
\hline Aroclor-1260 & 29-Jul-97 & BOK0F6 & 330 & $\mathrm{ug} / \mathrm{kg}$ & & $100-D-22$ \\
\hline Aroclor-1260 & 29-Jul-97 & BOKOF6 & 330 & $\mathrm{ug} / \mathrm{kg}$ & & 100-D-22 \\
\hline Aroclor-1260 & 29-Jul-97 & BOK0F6 & 330 & $\mathrm{ug} / \mathrm{kg}$ & & $100-D-22$ \\
\hline Aroclor-1260 & 29-Jul-97 & BOK0F6 & 330 & $\mathrm{ug} / \mathrm{kg}$ & & $100-D-22$ \\
\hline Aroclor-1242 & 29-Jul-97 & BOKOF7 & 380 & ug/kg & & $100-D-22$ \\
\hline Aroclor-1242 & 29-Jul-97 & BOK0F7 & 380 & $\mathrm{ug} / \mathrm{kg}$ & & $100-D-22$ \\
\hline Aroclor-1242 & 29-Jul-97 & BOKOF7 & 380 & $\mathrm{ug} / \mathrm{kg}$ & & $100-D-22$ \\
\hline
\end{tabular}




\begin{tabular}{|c|c|c|c|c|c|c|}
\hline Aroclor & $\begin{array}{l}\text { Sample } \\
\text { Date }\end{array}$ & $\begin{array}{l}\text { Sample } \\
\text { Number }\end{array}$ & Result & Units & Well Name & $\begin{array}{l}\text { Waste Site or } \\
\text { Well ID }\end{array}$ \\
\hline Aroclor-1242 & 29-Jul-97 & BOKOF7 & 380 & $\mathrm{ug} / \mathrm{kg}$ & & 100-D-22 \\
\hline Aroclor-1242 & 29-Jul-97 & BOKOF7 & 380 & ug/kg & & 100-D-22 \\
\hline Aroclor-1242 & 29-Jul-97 & BOK0F8 & 400 & ug/kg & & 100-D-22 \\
\hline Aroclor-1242 & 29-Jul-97 & BOK0F8 & 400 & $\mathrm{ug} / \mathrm{kg}$ & & 100-D-22 \\
\hline Aroclor-1242 & 29-Jul-97 & BOK0F8 & 400 & $\mathrm{ug} / \mathrm{kg}$ & & 100-D-22 \\
\hline Aroclor-1242 & 29-Jul-97 & BOK0F8 & 400 & $\mathrm{ug} / \mathrm{kg}$ & & $100-D-22$ \\
\hline Aroclor-1242 & 29-Jul-97 & BOK0F8 & 400 & $\mathrm{ug} / \mathrm{kg}$ & & $100-D-22$ \\
\hline Aroclor-1260 & 29-Jul-97 & BOKOF9 & 470 & $\mathrm{ug} / \mathrm{kg}$ & & 100-D-22 \\
\hline Aroclor-1260 & 29-Jul-97 & BOKOF9 & 470 & $\mathrm{ug} / \mathrm{kg}$ & & 100-D-22 \\
\hline Aroclor-1260 & 29-Jul-97 & BOKOF9 & 470 & $\mathrm{ug} / \mathrm{kg}$ & & 100-D-22 \\
\hline Aroclor-1260 & 29-Jul-97 & BOKOF9 & 470 & $\mathrm{ug} / \mathrm{kg}$ & & $100-D-22$ \\
\hline Aroclor-1260 & 29-Jul-97 & BOKOF9 & 470 & $\mathrm{ug} / \mathrm{kg}$ & & $100-D-22$ \\
\hline Aroclor-1260 & 29-Jul-97 & BOK0F7 & 580 & $\mathrm{ug} / \mathrm{kg}$ & & $100-D-22$ \\
\hline Aroclor-1260 & 29-Jul-97 & BOK0F7 & 580 & $\mathrm{ug} / \mathrm{kg}$ & & 100-D-22 \\
\hline Aroclor-1260 & 29-Jul-97 & BOK0F7 & 580 & $\mathrm{ug} / \mathrm{kg}$ & & $100-D-22$ \\
\hline Aroclor-1260 & 29-Jul-97 & BOKOF7 & 580 & $\mathrm{ug} / \mathrm{kg}$ & & $100-D-22$ \\
\hline Aroclor-1260 & 29-Jul-97 & BOKOF7 & 580 & $\mathrm{ug} / \mathrm{kg}$ & & 100-D-22 \\
\hline Aroclor-1260 & 29-Jul-97 & BOK0F8 & 640 & $\mathrm{ug} / \mathrm{kg}$ & & $100-D-22$ \\
\hline Aroclor-1260 & 29-Jul-97 & BOK0F8 & 640 & $\mathrm{ug} / \mathrm{kg}$ & & 100-D-22 \\
\hline Aroclor-1260 & 29-Jul-97 & BOK0F8 & 640 & $\mathrm{ug} / \mathrm{kg}$ & & $100-D-22$ \\
\hline Aroclor-1260 & 29-Jul-97 & BOKOF8 & 640 & $\mathrm{ug} / \mathrm{kg}$ & & $100-D-22$ \\
\hline Aroclor-1260 & 29-Jul-97 & BOK0F8 & 640 & $\mathrm{ug} / \mathrm{kg}$ & & 100-D-22 \\
\hline Aroclor-1016 & 17-Mar-97 & B0K0C5 & 4400 & $\mathrm{ug} / \mathrm{kg}$ & & $100-D-22$ \\
\hline Aroclor-1260 & 29-Jul-97 & BOK0F5 & 47000 & $\mathrm{ug} / \mathrm{kg}$ & & 100-D-22 \\
\hline Aroclor-1260 & 29-Jul-97 & B0K0F5 & 47000 & $\mathrm{ug} / \mathrm{kg}$ & & $100-D-22$ \\
\hline Aroclor-1260 & 29-Jul-97 & BOKOF5 & 47000 & $\mathrm{ug} / \mathrm{kg}$ & & $100-D-22$ \\
\hline Aroclor-1260 & 29-Jul-97 & B0K0F5 & 47000 & ug/kg & & $100-D-22$ \\
\hline Aroclor-1260 & 29-Jul-97 & B0K0F5 & 47000 & $\mathrm{ug} / \mathrm{kg}$ & & 100-D-22 \\
\hline Aroclor-1242 & 18-Feb-99 & B0TV50 & 43 & $\mathrm{ug} / \mathrm{kg}$ & & 100-D-25 \\
\hline Aroclor-1242 & 18-Feb-99 & B0TV50 & 43 & $\mathrm{ug} / \mathrm{kg}$ & & $100-D-25$ \\
\hline Aroclor-1260 & 18-Feb-99 & B0TV50 & 130 & $\mathrm{ug} / \mathrm{kg}$ & & 100-D-25 \\
\hline Aroclor-1260 & 18-Feb-99 & B0TV50 & 130 & $\mathrm{ug} / \mathrm{kg}$ & & $100-D-25$ \\
\hline Aroclor-1254 & 28-Jul-97 & BOKON4 & 71 & $\mathrm{ug} / \mathrm{kg}$ & & $100-D-4$ \\
\hline Aroclor-1254 & 28-Jul-97 & BOKON4 & 71 & $\mathrm{ug} / \mathrm{kg}$ & & $100-D-4$ \\
\hline Aroclor-1254 & 28-Jul-97 & BOKON4 & 71 & $\mathrm{ug} / \mathrm{kg}$ & & $100-D-4$ \\
\hline Aroclor-1254 & 28-Jul-97 & BOKON4 & 71 & $\mathrm{ug} / \mathrm{kg}$ & & 100-D-4 \\
\hline Aroclor-1254 & 28-Jul-97 & BOKON4 & 71 & $\mathrm{ug} / \mathrm{kg}$ & & 100-D-4 \\
\hline Aroclor-1260 & 28-Jul-97 & BOKON4 & 120 & $\mathrm{ug} / \mathrm{kg}$ & & 100-D-4 \\
\hline
\end{tabular}




\begin{tabular}{|c|c|c|c|c|c|c|}
\hline Aroclor & $\begin{array}{l}\text { Sample } \\
\text { Date }\end{array}$ & $\begin{array}{l}\text { Sample } \\
\text { Number }\end{array}$ & Result & Units & Well Name & $\begin{array}{l}\text { Waste Site or } \\
\text { Well ID }\end{array}$ \\
\hline Aroclor-1260 & 28-Jul-97 & BOKON4 & 120 & $\mathrm{ug} / \mathrm{kg}$ & & 100-D-4 \\
\hline Aroclor-1260 & 28-Jul-97 & BOKON4 & 120 & $\mathrm{ug} / \mathrm{kg}$ & & $100-D-4$ \\
\hline Aroclor-1260 & 28-Jul-97 & BOKON4 & 120 & $\mathrm{ug} / \mathrm{kg}$ & & $100-D-4$ \\
\hline Aroclor-1260 & 28-Jul-97 & BOKON4 & 120 & $\mathrm{ug} / \mathrm{kg}$ & & $100-D-4$ \\
\hline Aroclor-1260 & $11-O c t-04$ & J01XR3 & 46 & $\mathrm{ug} / \mathrm{kg}$ & & $100-F-12$ \\
\hline Aroclor-1260 & $11-O c t-04$ & J01XR4 & 55 & $\mathrm{ug} / \mathrm{kg}$ & & $100-F-12$ \\
\hline Aroclor-1260 & 11-Oct-04 & J01XV2 & 240 & $\mathrm{ug} / \mathrm{kg}$ & & $100-F-12$ \\
\hline Aroclor-1254 & 04-Jan-05 & J024L3 & 14 & $\mathrm{ug} / \mathrm{kg}$ & & 100-F-26:1 \\
\hline Aroclor-1254 & 04-Jan-05 & J026X8 & 14 & $\mathrm{ug} / \mathrm{kg}$ & & 100-F-26:1 \\
\hline Aroclor-1260 & 10-Dec-04 & J024L1 & 18 & $\mathrm{ug} / \mathrm{kg}$ & & 100-F-26:1 \\
\hline Aroclor-1260 & 17-Nov-04 & J022R2 & 14 & $\mathrm{ug} / \mathrm{kg}$ & & $100-F-26: 2$ \\
\hline Aroclor-1254 & 22-Dec-04 & J024P0 & 65 & $\mathrm{ug} / \mathrm{kg}$ & & $100-F-26: 4$ \\
\hline Aroclor-1254 & 04-Jan-05 & J026X4 & 35 & $\mathrm{ug} / \mathrm{kg}$ & & $100-F-26: 5$ \\
\hline Aroclor-1254 & 03-Jan-05 & J025K5 & 14 & $\mathrm{ug} / \mathrm{kg}$ & & $100-F-26: 9$ \\
\hline Aroclor-1260 & 28-Dec-04 & J025J6 & 28 & ug/kg & & $100-F-26: 9$ \\
\hline Aroclor-1254 & 28-Dec-04 & $\mathrm{J} 025 \mathrm{KO}$ & 46 & $\mathrm{ug} / \mathrm{kg}$ & & $100-F-26: 9$ \\
\hline Aroclor-1254 & 03-Jan-05 & J026D2 & 180 & $\mathrm{ug} / \mathrm{kg}$ & & $100-F-26: 9$ \\
\hline Aroclor-1254 & 27-Dec-04 & J025J5 & 190 & $\mathrm{ug} / \mathrm{kg}$ & & $100-F-26: 9$ \\
\hline Aroclor-1254 & 27-Dec-04 & J025J1 & 620 & $\mathrm{ug} / \mathrm{kg}$ & & $100-F-26: 9$ \\
\hline Aroclor-1254 & 17-May-06 & J12679 & 14 & $\mathrm{ug} / \mathrm{kg}$ & & $100-F-31$ \\
\hline Aroclor-1254 & 06-Feb-06 & J112F1 & 20 & $\mathrm{ug} / \mathrm{kg}$ & & 100-F-31 \\
\hline Aroclor-1254 & 17-May-06 & $\mathrm{J} 12671$ & 30 & $\mathrm{ug} / \mathrm{kg}$ & & 100-F-31 \\
\hline Aroclor-1254 & 06-Feb-06 & J112F0 & 31 & ug/kg & & $100-F-31$ \\
\hline Aroclor-1254 & 06-Feb-06 & J112D7 & 71 & ug/kg & & 100-F-31 \\
\hline Aroclor-1254 & 24-Sep-04 & J01THO & 16 & $\mathrm{ug} / \mathrm{kg}$ & & $100-F-33$ \\
\hline Aroclor-1254 & 24-Jan-06 & J111T8 & 16 & $\mathrm{ug} / \mathrm{kg}$ & & $100-F-33$ \\
\hline Aroclor-1254 & 24-Jan-06 & J111V3 & 21 & $\mathrm{ug} / \mathrm{kg}$ & & $100-F-33$ \\
\hline Aroclor-1254 & 28-Sep-04 & J01TH2 & 23 & $\mathrm{ug} / \mathrm{kg}$ & & 100-F-33 \\
\hline Aroclor-1254 & 24-Sep-04 & J01TF9 & 24 & $\mathrm{ug} / \mathrm{kg}$ & & 100-F-33 \\
\hline Aroclor-1254 & 24-Jan-06 & J111V2 & 24 & $\mathrm{ug} / \mathrm{kg}$ & & 100-F-33 \\
\hline Aroclor-1254 & 24-Sep-04 & J01TH3 & 27 & $\mathrm{ug} / \mathrm{kg}$ & & 100-F-33 \\
\hline Aroclor-1254 & 24-Jan-06 & J111V7 & 48 & $\mathrm{ug} / \mathrm{kg}$ & & $100-F-33$ \\
\hline Aroclor-1254 & 23-Sep-04 & J01TF8 & 94 & ug/kg & & $100-F-33$ \\
\hline Aroclor-1254 & 24-Jan-06 & J111V5 & 100 & $\mathrm{ug} / \mathrm{kg}$ & & 100-F-33 \\
\hline Aroclor-1254 & 24-Jan-06 & J111T9 & 110 & $\mathrm{ug} / \mathrm{kg}$ & & 100-F-33 \\
\hline Aroclor-1254 & 24-Jan-06 & J111T5 & 210 & $\mathrm{ug} / \mathrm{kg}$ & & $100-F-33$ \\
\hline Aroclor-1254 & 24-Jan-06 & J111T4 & 260 & $\mathrm{ug} / \mathrm{kg}$ & & $100-F-33$ \\
\hline Aroclor-1260 & 05-Dec-06 & J13VJ0 & 17 & $\mathrm{ug} / \mathrm{kg}$ & & $100-F-36$ \\
\hline
\end{tabular}




\begin{tabular}{|c|c|c|c|c|c|c|}
\hline Aroclor & $\begin{array}{l}\text { Sample } \\
\text { Date }\end{array}$ & $\begin{array}{l}\text { Sample } \\
\text { Number }\end{array}$ & Result & Units & Well Name & $\begin{array}{l}\text { Waste Site or } \\
\text { Well ID }\end{array}$ \\
\hline Aroclor-1254 & 05-Dec-06 & J13VJ0 & 28 & $\mathrm{ug} / \mathrm{kg}$ & & $100-F-36$ \\
\hline Aroclor-1260 & 02-Nov-05 & J10FT0 & 15 & ug/kg & & 100-F-38 \\
\hline Aroclor-1260 & 02-Nov-05 & J10FT2 & 32 & $\mathrm{ug} / \mathrm{kg}$ & & 100-F-38 \\
\hline Aroclor-1260 & 09-Mar-93 & B080R4 & 720 & $\mathrm{ug} / \mathrm{kg}$ & & $100-F-15$ \\
\hline Aroclor-1254 & 09-Mar-93 & B080R4 & 1600 & $\mathrm{ug} / \mathrm{kg}$ & & 100-F-15 \\
\hline Aroclor-1260 & 04-Aug-00 & BOYXF2 & 38 & $\mathrm{ug} / \mathrm{kg}$ & & $100-\mathrm{H}-24$ \\
\hline Aroclor-1260 & 04-Aug-00 & BOYXNO & 38 & $\mathrm{ug} / \mathrm{kg}$ & & $100-\mathrm{H}-24$ \\
\hline Aroclor-1260 & 04-Aug-00 & B0YXN5 & 46 & $\mathrm{ug} / \mathrm{kg}$ & & $100-\mathrm{H}-24$ \\
\hline Aroclor-1260 & 04-Aug-00 & BOYXH9 & 49 & $\mathrm{ug} / \mathrm{kg}$ & & $100-\mathrm{H}-24$ \\
\hline Aroclor-1260 & 04-Aug-00 & B0YXR1 & 54 & $\mathrm{ug} / \mathrm{kg}$ & & $100-\mathrm{H}-24$ \\
\hline Aroclor-1260 & 04-Aug-00 & B0YXJ9 & 89 & $\mathrm{ug} / \mathrm{kg}$ & & $100-\mathrm{H}-24$ \\
\hline Aroclor-1260 & 04-Aug-00 & BOYXL4 & 100 & $\mathrm{ug} / \mathrm{kg}$ & & $100-\mathrm{H}-24$ \\
\hline Aroclor-1260 & 04-Aug-00 & B0YXJ1 & 150 & $\mathrm{ug} / \mathrm{kg}$ & & $100-\mathrm{H}-24$ \\
\hline Aroclor-1260 & 04-Aug-00 & B0YXJ8 & 150 & $\mathrm{ug} / \mathrm{kg}$ & & $100-\mathrm{H}-24$ \\
\hline Aroclor-1260 & 04-Aug-00 & BOYXL3 & 160 & $\mathrm{ug} / \mathrm{kg}$ & & $100-\mathrm{H}-24$ \\
\hline Aroclor-1260 & 04-Aug-00 & BOYXH4 & 200 & $\mathrm{ug} / \mathrm{kg}$ & & $100-\mathrm{H}-24$ \\
\hline Aroclor-1260 & 04-Aug-00 & BOYXLO & 230.004 & $\mathrm{ug} / \mathrm{kg}$ & & $100-\mathrm{H}-24$ \\
\hline Aroclor-1260 & 11-Dec-00 & B112V7 & 290 & $\mathrm{ug} / \mathrm{kg}$ & & $100-\mathrm{H}-24$ \\
\hline Aroclor-1254 & 09-Dec-91 & B018S8 & 350 & $\mathrm{ug} / \mathrm{kg}$ & & $100-\mathrm{H}-24$ \\
\hline Aroclor-1260 & 04-Aug-00 & BOYXL6 & 350 & $\mathrm{ug} / \mathrm{kg}$ & & $100-\mathrm{H}-24$ \\
\hline Aroclor-1260 & 04-Aug-00 & BOYXK8 & 600 & $\mathrm{ug} / \mathrm{kg}$ & & $100-\mathrm{H}-24$ \\
\hline Aroclor-1260 & 04-Aug-00 & BOYXK4 & 680 & $\mathrm{ug} / \mathrm{kg}$ & & $100-\mathrm{H}-24$ \\
\hline Aroclor-1260 & 11-Dec-00 & B112V2 & 690 & $\mathrm{ug} / \mathrm{kg}$ & & $100-\mathrm{H}-24$ \\
\hline Aroclor-1260 & 04-Aug-00 & BOYXK7 & 750.006 & $\mathrm{ug} / \mathrm{kg}$ & & $100-\mathrm{H}-24$ \\
\hline Aroclor-1260 & 04-Aug-00 & BOYXK5 & 890 & $\mathrm{ug} / \mathrm{kg}$ & & $100-\mathrm{H}-24$ \\
\hline Aroclor-1260 & $11-D e c-00$ & B112V6 & 1600.09 & $\mathrm{ug} / \mathrm{kg}$ & & $100-\mathrm{H}-24$ \\
\hline Aroclor-1260 & 04-Aug-00 & BOYXK9 & 1900 & $\mathrm{ug} / \mathrm{kg}$ & & $100-\mathrm{H}-24$ \\
\hline Aroclor-1260 & 04-Aug-00 & B0YXL1 & 2300 & $\mathrm{ug} / \mathrm{kg}$ & & $100-\mathrm{H}-24$ \\
\hline Aroclor-1260 & 23-May-00 & B0X4W3 & 32.85 & $\mathrm{ug} / \mathrm{kg}$ & & $100-\mathrm{H}-5$ \\
\hline Aroclor-1260 & 23-May-00 & B0X4W3 & 32.85 & $\mathrm{ug} / \mathrm{kg}$ & & $100-\mathrm{H}-5$ \\
\hline Aroclor-1260 & 23-May-00 & B0X4W3 & 32.85 & $\mathrm{ug} / \mathrm{kg}$ & & $100-\mathrm{H}-5$ \\
\hline Aroclor-1260 & 23-May-00 & B0X4W3 & 32.85 & $\mathrm{ug} / \mathrm{kg}$ & & $100-\mathrm{H}-5$ \\
\hline Aroclor-1260 & 23-May-00 & B0X4W3 & 32.85 & $\mathrm{ug} / \mathrm{kg}$ & & $100-\mathrm{H}-5$ \\
\hline Aroclor-1248 & 08-Jun-00 & BOYC72 & 90 & $\mathrm{ug} / \mathrm{kg}$ & & $100-\mathrm{H}-5$ \\
\hline Aroclor-1248 & 08-Jun-00 & BOYC72 & 90 & $\mathrm{ug} / \mathrm{kg}$ & & $100-\mathrm{H}-5$ \\
\hline Aroclor-1248 & 08-Jun-00 & BOYC72 & 90 & $\mathrm{ug} / \mathrm{kg}$ & & $100-\mathrm{H}-5$ \\
\hline Aroclor-1248 & 08-Jun-00 & B0YC72 & 90 & $\mathrm{ug} / \mathrm{kg}$ & & $100-\mathrm{H}-5$ \\
\hline Aroclor-1248 & 08-Jun-00 & B0YC72 & 90 & $\mathrm{ug} / \mathrm{kg}$ & & $100-\mathrm{H}-5$ \\
\hline
\end{tabular}




\begin{tabular}{|c|c|c|c|c|c|c|}
\hline Aroclor & $\begin{array}{l}\text { Sample } \\
\text { Date }\end{array}$ & $\begin{array}{l}\text { Sample } \\
\text { Number }\end{array}$ & Result & Units & Well Name & $\begin{array}{c}\text { Waste Site or } \\
\text { Well ID }\end{array}$ \\
\hline Aroclor-1254 & 15-Apr-03 & J00LB9 & 98 & $\mathrm{ug} / \mathrm{kg}$ & & $100-K-29$ \\
\hline Aroclor-1254 & 15-Apr-03 & J00LB7 & 110 & $\mathrm{ug} / \mathrm{kg}$ & & $100-K-29$ \\
\hline Aroclor-1254 & 15-Apr-03 & J00LB7 & 110 & $\mathrm{ug} / \mathrm{kg}$ & & $100-K-29$ \\
\hline Aroclor-1254 & 15-Apr-03 & J00LB7 & 110 & $\mathrm{ug} / \mathrm{kg}$ & & $100-K-29$ \\
\hline Aroclor-1254 & 15-Apr-03 & J00LB7 & 110 & $\mathrm{ug} / \mathrm{kg}$ & & $100-K-29$ \\
\hline Aroclor-1254 & 15-Apr-03 & J00LB7 & 110 & $\mathrm{ug} / \mathrm{kg}$ & & $100-K-29$ \\
\hline Aroclor-1254 & 15-Apr-03 & J00LB7 & 110 & ug/kg & & $100-K-29$ \\
\hline Aroclor-1254 & 15-Apr-03 & J00LB7 & 110 & ug/kg & & $100-K-29$ \\
\hline Aroclor-1254 & 15-Apr-03 & J00LB7 & 110 & $\mathrm{ug} / \mathrm{kg}$ & & $100-K-29$ \\
\hline Aroclor-1254 & 15-Apr-03 & J00LB7 & 110 & $\mathrm{ug} / \mathrm{kg}$ & & $100-K-29$ \\
\hline Aroclor-1254 & 15-Apr-03 & J00LB7 & 110 & $\mathrm{ug} / \mathrm{kg}$ & & $100-K-29$ \\
\hline Aroclor-1254 & 15-Apr-03 & J00LB7 & 110 & ug/kg & & $100-K-29$ \\
\hline Aroclor-1254 & 15-Apr-03 & J00LB7 & 110 & $\mathrm{ug} / \mathrm{kg}$ & & $100-\mathrm{K}-29$ \\
\hline Aroclor-1254 & 15-Apr-03 & J00LB7 & 110 & $\mathrm{ug} / \mathrm{kg}$ & & $100-K-29$ \\
\hline Aroclor-1254 & 15-Apr-03 & J00LB7 & 110 & $\mathrm{ug} / \mathrm{kg}$ & & $100-K-29$ \\
\hline Aroclor-1254 & 15-Apr-03 & J00LB7 & 110 & $\mathrm{ug} / \mathrm{kg}$ & & $100-K-29$ \\
\hline Aroclor-1254 & 15-Apr-03 & J00LB7 & 110 & $\mathrm{ug} / \mathrm{kg}$ & & $100-K-29$ \\
\hline Aroclor-1254 & 15-Apr-03 & J00LB7 & 110 & $\mathrm{ug} / \mathrm{kg}$ & & $100-K-29$ \\
\hline Aroclor-1254 & 15-Apr-03 & J00LB6 & 120 & $\mathrm{ug} / \mathrm{kg}$ & & $100-K-29$ \\
\hline Aroclor-1254 & 15-Apr-03 & J00LB6 & 120 & $\mathrm{ug} / \mathrm{kg}$ & & $100-K-29$ \\
\hline Aroclor-1254 & 15-Apr-03 & J00LB6 & 120 & $\mathrm{ug} / \mathrm{kg}$ & & $100-K-29$ \\
\hline Aroclor-1254 & 15-Apr-03 & J00LB6 & 120 & ug/kg & & $100-K-29$ \\
\hline Aroclor-1254 & 15-Apr-03 & J00LB6 & 120 & $\mathrm{ug} / \mathrm{kg}$ & & $100-K-29$ \\
\hline Aroclor-1254 & 15-Apr-03 & J00LB6 & 120 & $\mathrm{ug} / \mathrm{kg}$ & & $100-K-29$ \\
\hline Aroclor-1254 & 15-Apr-03 & J00LB6 & 120 & $\mathrm{ug} / \mathrm{kg}$ & & $100-K-29$ \\
\hline Aroclor-1254 & 15-Apr-03 & J00LB6 & 120 & ug/kg & & $100-K-29$ \\
\hline Aroclor-1254 & 15-Apr-03 & J00LB6 & 120 & $\mathrm{ug} / \mathrm{kg}$ & & $100-K-29$ \\
\hline Aroclor-1254 & 15-Apr-03 & J00LB6 & 120 & $\mathrm{ug} / \mathrm{kg}$ & & $100-K-29$ \\
\hline Aroclor-1254 & 15-Apr-03 & J00LB6 & 120 & $\mathrm{ug} / \mathrm{kg}$ & & $100-K-29$ \\
\hline Aroclor-1254 & 15-Apr-03 & J00LB6 & 120 & $\mathrm{ug} / \mathrm{kg}$ & & $100-K-29$ \\
\hline Aroclor-1254 & 15-Apr-03 & J00LB6 & 120 & $\mathrm{ug} / \mathrm{kg}$ & & 100-K-29 \\
\hline Aroclor-1254 & 15-Apr-03 & J00LB6 & 120 & $\mathrm{ug} / \mathrm{kg}$ & & $100-K-29$ \\
\hline Aroclor-1254 & 15-Apr-03 & J00LB6 & 120 & $\mathrm{ug} / \mathrm{kg}$ & & $100-K-29$ \\
\hline Aroclor-1254 & 15-Apr-03 & J00LB6 & 120 & $\mathrm{ug} / \mathrm{kg}$ & & $100-K-29$ \\
\hline Aroclor-1254 & 15-Apr-03 & J00LB6 & 120 & $\mathrm{ug} / \mathrm{kg}$ & & $100-K-29$ \\
\hline Aroclor-1254 & 15-Apr-03 & J00LB8 & 240 & $\mathrm{ug} / \mathrm{kg}$ & & $100-K-29$ \\
\hline Aroclor-1254 & 15-Apr-03 & J00LB8 & 240 & $\mathrm{ug} / \mathrm{kg}$ & & $100-K-29$ \\
\hline Aroclor-1254 & 15-Apr-03 & J00LB8 & 240 & $\mathrm{ug} / \mathrm{kg}$ & & $100-\mathrm{K}-29$ \\
\hline
\end{tabular}




\begin{tabular}{|c|c|c|c|c|c|c|}
\hline Aroclor & $\begin{array}{l}\text { Sample } \\
\text { Date }\end{array}$ & $\begin{array}{l}\text { Sample } \\
\text { Number }\end{array}$ & Result & Units & Well Name & $\begin{array}{l}\text { Waste Site or } \\
\text { Well ID }\end{array}$ \\
\hline Aroclor-1254 & 15-Apr-03 & J00LB8 & 240 & $\mathrm{ug} / \mathrm{kg}$ & & $100-K-29$ \\
\hline Aroclor-1254 & 15-Apr-03 & J00LB8 & 240 & $\mathrm{ug} / \mathrm{kg}$ & & $100-K-29$ \\
\hline Aroclor-1254 & 15-Apr-03 & J00LB8 & 240 & $\mathrm{ug} / \mathrm{kg}$ & & $100-K-29$ \\
\hline Aroclor-1254 & 15-Apr-03 & J00LB8 & 240 & $\mathrm{ug} / \mathrm{kg}$ & & $100-K-29$ \\
\hline Aroclor-1254 & 15-Apr-03 & J00LB8 & 240 & $\mathrm{ug} / \mathrm{kg}$ & & $100-K-29$ \\
\hline Aroclor-1254 & 15-Apr-03 & J00LB8 & 240 & $\mathrm{ug} / \mathrm{kg}$ & & $100-K-29$ \\
\hline Aroclor-1254 & 15-Apr-03 & J00LB8 & 240 & $\mathrm{ug} / \mathrm{kg}$ & & $100-K-29$ \\
\hline Aroclor-1254 & 15-Apr-03 & J00LB8 & 240 & $\mathrm{ug} / \mathrm{kg}$ & & $100-K-29$ \\
\hline Aroclor-1254 & 15-Apr-03 & J00LB8 & 240 & $\mathrm{ug} / \mathrm{kg}$ & & $100-K-29$ \\
\hline Aroclor-1254 & 15-Apr-03 & J00LB8 & 240 & $\mathrm{ug} / \mathrm{kg}$ & & $100-K-29$ \\
\hline Aroclor-1254 & 15-Apr-03 & J00LB8 & 240 & $\mathrm{ug} / \mathrm{kg}$ & & $100-K-29$ \\
\hline Aroclor-1254 & 15-Apr-03 & J00LB8 & 240 & $\mathrm{ug} / \mathrm{kg}$ & & $100-K-29$ \\
\hline Aroclor-1254 & 15-Apr-03 & J00LB8 & 240 & $\mathrm{ug} / \mathrm{kg}$ & & $100-K-29$ \\
\hline Aroclor-1254 & 15-Apr-03 & J00LB8 & 240 & ug/kg & & $100-K-29$ \\
\hline Aroclor-1260 & 28-Dec-05 & J10W43 & 32 & ug/kg & & $100-N-54$ \\
\hline Aroclor-1260 & 28-Dec-05 & J10W42 & 43 & $\mathrm{ug} / \mathrm{kg}$ & & $100-N-54$ \\
\hline Aroclor-1254 & 28-Jul-95 & B0G8S1 & 130 & $\mathrm{ug} / \mathrm{kg}$ & & 116-B-4 \\
\hline Aroclor-1260 & 09-Jun-98 & B0P0D9 & 36 & $\mathrm{ug} / \mathrm{kg}$ & & 116-DR-9 \\
\hline Aroclor-1260 & 18-Feb-99 & B0TV41 & 36 & $\mathrm{ug} / \mathrm{kg}$ & & 116-DR-9 \\
\hline Aroclor-1260 & 18-Feb-99 & B0TV41 & 36 & $\mathrm{ug} / \mathrm{kg}$ & & 116-DR-9 \\
\hline Aroclor-1260 & 18-Feb-99 & B0TV41 & 36 & $\mathrm{ug} / \mathrm{kg}$ & & 116-DR-9 \\
\hline Aroclor-1260 & 18-Feb-99 & B0TV41 & 36 & $\mathrm{ug} / \mathrm{kg}$ & & 116-DR-9 \\
\hline Aroclor-1260 & 18-Feb-99 & B0TV41 & 36 & ug/kg & & 116-DR-9 \\
\hline Aroclor-1260 & 18-Feb-99 & B0TV48 & 36.1 & ug/kg & & 116-DR-9 \\
\hline Aroclor-1260 & 18-Feb-99 & B0TV48 & 36.1 & $\mathrm{ug} / \mathrm{kg}$ & & 116-DR-9 \\
\hline Aroclor-1260 & 18-Feb-99 & B0TV48 & 36.1 & $\mathrm{ug} / \mathrm{kg}$ & & 116-DR-9 \\
\hline Aroclor-1260 & 18-Feb-99 & B0TV48 & 36.1 & $\mathrm{ug} / \mathrm{kg}$ & & 116-DR-9 \\
\hline Aroclor-1260 & 18-Feb-99 & B0TV48 & 36.1 & $\mathrm{ug} / \mathrm{kg}$ & & 116-DR-9 \\
\hline Aroclor-1260 & 09-Sep-98 & BOPVH2 & 37 & $\mathrm{ug} / \mathrm{kg}$ & & 116-DR-9 \\
\hline Aroclor-1254 & 24-Jul-98 & B0PCY1 & 38 & $\mathrm{ug} / \mathrm{kg}$ & & 116-DR-9 \\
\hline Aroclor-1242 & 18-Feb-99 & B0TV50 & 43 & $\mathrm{ug} / \mathrm{kg}$ & & 116-DR-9 \\
\hline Aroclor-1242 & 18-Feb-99 & B0TV50 & 43 & $\mathrm{ug} / \mathrm{kg}$ & & 116-DR-9 \\
\hline Aroclor-1242 & 18-Feb-99 & B0TV50 & 43 & $\mathrm{ug} / \mathrm{kg}$ & & 116-DR-9 \\
\hline Aroclor-1242 & 18-Feb-99 & B0TV50 & 43 & $\mathrm{ug} / \mathrm{kg}$ & & 116-DR-9 \\
\hline Aroclor-1242 & 18-Feb-99 & B0TV50 & 43 & $\mathrm{ug} / \mathrm{kg}$ & & 116-DR-9 \\
\hline Aroclor-1260 & 09-Jun-98 & B0P0D5 & 48 & $\mathrm{ug} / \mathrm{kg}$ & & 116-DR-9 \\
\hline Aroclor-1260 & 09-Jun-98 & B0P0D8 & 50 & $\mathrm{ug} / \mathrm{kg}$ & & 116-DR-9 \\
\hline Aroclor-1254 & 24-Jul-98 & B0PCX9 & 55 & $\mathrm{ug} / \mathrm{kg}$ & & 116-DR-9 \\
\hline
\end{tabular}




\begin{tabular}{|c|c|c|c|c|c|c|}
\hline Aroclor & $\begin{array}{l}\text { Sample } \\
\text { Date }\end{array}$ & $\begin{array}{l}\text { Sample } \\
\text { Number }\end{array}$ & Result & Units & Well Name & $\begin{array}{l}\text { Waste Site or } \\
\text { Well ID }\end{array}$ \\
\hline Aroclor-1242 & 18-Feb-99 & B0TV37 & 58 & $\mathrm{ug} / \mathrm{kg}$ & & 116-DR-9 \\
\hline Aroclor-1242 & 18-Feb-99 & B0TV37 & 58 & $\mathrm{ug} / \mathrm{kg}$ & & 116-DR-9 \\
\hline Aroclor-1242 & 18-Feb-99 & B0TV37 & 58 & $\mathrm{ug} / \mathrm{kg}$ & & 116-DR-9 \\
\hline Aroclor-1242 & 18-Feb-99 & B0TV37 & 58 & $\mathrm{ug} / \mathrm{kg}$ & & 116-DR-9 \\
\hline Aroclor-1242 & 18-Feb-99 & B0TV37 & 58 & $\mathrm{ug} / \mathrm{kg}$ & & 116-DR-9 \\
\hline Aroclor-1260 & 24-Jul-98 & BOPCY2 & 58 & $\mathrm{ug} / \mathrm{kg}$ & & 116-DR-9 \\
\hline Aroclor-1260 & 16-Sep-98 & BOPVH9 & 59 & $\mathrm{ug} / \mathrm{kg}$ & & 116-DR-9 \\
\hline Aroclor-1242 & 18-Feb-99 & B0TV42 & 60 & $\mathrm{ug} / \mathrm{kg}$ & & 116-DR-9 \\
\hline Aroclor-1242 & 18-Feb-99 & B0TV42 & 60 & $\mathrm{ug} / \mathrm{kg}$ & & 116-DR-9 \\
\hline Aroclor-1242 & 18-Feb-99 & B0TV42 & 60 & $\mathrm{ug} / \mathrm{kg}$ & & 116-DR-9 \\
\hline Aroclor-1242 & 18-Feb-99 & B0TV42 & 60 & $\mathrm{ug} / \mathrm{kg}$ & & 116-DR-9 \\
\hline Aroclor-1242 & 18-Feb-99 & B0TV42 & 60 & $\mathrm{ug} / \mathrm{kg}$ & & 116-DR-9 \\
\hline Aroclor-1242 & 18-Feb-99 & B0TV38 & 68 & $\mathrm{ug} / \mathrm{kg}$ & & 116-DR-9 \\
\hline Aroclor-1242 & 18-Feb-99 & B0TV38 & 68 & ug/kg & & 116-DR-9 \\
\hline Aroclor-1242 & 18-Feb-99 & B0TV38 & 68 & ug/kg & & 116-DR-9 \\
\hline Aroclor-1242 & 18-Feb-99 & B0TV38 & 68 & $\mathrm{ug} / \mathrm{kg}$ & & 116-DR-9 \\
\hline Aroclor-1242 & 18-Feb-99 & B0TV38 & 68 & $\mathrm{ug} / \mathrm{kg}$ & & 116-DR-9 \\
\hline Aroclor-1242 & 18-Feb-99 & B0TV39 & 73 & $\mathrm{ug} / \mathrm{kg}$ & & 116-DR-9 \\
\hline Aroclor-1242 & 18-Feb-99 & B0TV39 & 73 & $\mathrm{ug} / \mathrm{kg}$ & & 116-DR-9 \\
\hline Aroclor-1242 & 18-Feb-99 & B0TV39 & 73 & $\mathrm{ug} / \mathrm{kg}$ & & 116-DR-9 \\
\hline Aroclor-1242 & 18-Feb-99 & B0TV39 & 73 & $\mathrm{ug} / \mathrm{kg}$ & & 116-DR-9 \\
\hline Aroclor-1242 & 18-Feb-99 & B0TV39 & 73 & $\mathrm{ug} / \mathrm{kg}$ & & 116-DR-9 \\
\hline Aroclor-1260 & 18-Feb-99 & B0TV40 & 77 & ug/kg & & 116-DR-9 \\
\hline Aroclor-1260 & 18-Feb-99 & B0TV40 & 77 & ug/kg & & 116-DR-9 \\
\hline Aroclor-1260 & 18-Feb-99 & B0TV40 & 77 & $\mathrm{ug} / \mathrm{kg}$ & & 116-DR-9 \\
\hline Aroclor-1260 & 18-Feb-99 & B0TV40 & 77 & $\mathrm{ug} / \mathrm{kg}$ & & 116-DR-9 \\
\hline Aroclor-1260 & 18-Feb-99 & B0TV40 & 77 & $\mathrm{ug} / \mathrm{kg}$ & & 116-DR-9 \\
\hline Aroclor-1260 & 18-Feb-99 & B0TV51 & 80 & $\mathrm{ug} / \mathrm{kg}$ & & 116-DR-9 \\
\hline Aroclor-1260 & 18-Feb-99 & B0TV51 & 80 & $\mathrm{ug} / \mathrm{kg}$ & & 116-DR-9 \\
\hline Aroclor-1260 & 18-Feb-99 & B0TV51 & 80 & $\mathrm{ug} / \mathrm{kg}$ & & 116-DR-9 \\
\hline Aroclor-1260 & 18-Feb-99 & B0TV51 & 80 & $\mathrm{ug} / \mathrm{kg}$ & & 116-DR-9 \\
\hline Aroclor-1260 & 18-Feb-99 & B0TV51 & 80 & $\mathrm{ug} / \mathrm{kg}$ & & 116-DR-9 \\
\hline Aroclor-1260 & 18-Feb-98 & B0N6C6 & 82 & $\mathrm{ug} / \mathrm{kg}$ & & 116-DR-9 \\
\hline Aroclor-1260 & 18-Feb-98 & B0N6C8 & 99 & $\mathrm{ug} / \mathrm{kg}$ & & 116-DR-9 \\
\hline Aroclor-1242 & 19-Dec-97 & B0MP36 & 100 & $\mathrm{ug} / \mathrm{kg}$ & & 116-DR-9 \\
\hline Aroclor-1242 & 18-Feb-99 & B0TV40 & 110 & $\mathrm{ug} / \mathrm{kg}$ & & 116-DR-9 \\
\hline Aroclor-1242 & 18-Feb-99 & B0TV40 & 110 & $\mathrm{ug} / \mathrm{kg}$ & & 116-DR-9 \\
\hline Aroclor-1242 & 18-Feb-99 & B0TV40 & 110 & $\mathrm{ug} / \mathrm{kg}$ & & 116-DR-9 \\
\hline
\end{tabular}




\begin{tabular}{|c|c|c|c|c|c|c|}
\hline Aroclor & $\begin{array}{l}\text { Sample } \\
\text { Date }\end{array}$ & $\begin{array}{l}\text { Sample } \\
\text { Number }\end{array}$ & Result & Units & Well Name & $\begin{array}{l}\text { Waste Site or } \\
\text { Well ID }\end{array}$ \\
\hline Aroclor-1242 & 18-Feb-99 & B0TV40 & 110 & $\mathrm{ug} / \mathrm{kg}$ & & 116-DR-9 \\
\hline Aroclor-1242 & 18-Feb-99 & B0TV40 & 110 & $\mathrm{ug} / \mathrm{kg}$ & & 116-DR-9 \\
\hline Aroclor-1260 & 18-Feb-99 & B0TV47 & 120 & $\mathrm{ug} / \mathrm{kg}$ & & 116-DR-9 \\
\hline Aroclor-1260 & 18-Feb-99 & B0TV47 & 120 & $\mathrm{ug} / \mathrm{kg}$ & & 116-DR-9 \\
\hline Aroclor-1260 & 18-Feb-99 & B0TV47 & 120 & $\mathrm{ug} / \mathrm{kg}$ & & 116-DR-9 \\
\hline Aroclor-1260 & 18-Feb-99 & B0TV47 & 120 & $\mathrm{ug} / \mathrm{kg}$ & & 116-DR-9 \\
\hline Aroclor-1260 & 18-Feb-99 & B0TV47 & 120 & $\mathrm{ug} / \mathrm{kg}$ & & 116-DR-9 \\
\hline Aroclor-1254 & 24-Jul-98 & B0PCX8 & 130 & $\mathrm{ug} / \mathrm{kg}$ & & 116-DR-9 \\
\hline Aroclor-1260 & 18-Feb-99 & B0TV50 & 130 & $\mathrm{ug} / \mathrm{kg}$ & & 116-DR-9 \\
\hline Aroclor-1260 & 18-Feb-99 & B0TV50 & 130 & $\mathrm{ug} / \mathrm{kg}$ & & 116-DR-9 \\
\hline Aroclor-1260 & 18-Feb-99 & B0TV50 & 130 & $\mathrm{ug} / \mathrm{kg}$ & & 116-DR-9 \\
\hline Aroclor-1260 & 18-Feb-99 & B0TV50 & 130 & $\mathrm{ug} / \mathrm{kg}$ & & 116-DR-9 \\
\hline Aroclor-1260 & 18-Feb-99 & B0TV50 & 130 & $\mathrm{ug} / \mathrm{kg}$ & & 116-DR-9 \\
\hline Aroclor-1260 & 09-Sep-98 & BOPVJ3 & 140 & $\mathrm{ug} / \mathrm{kg}$ & & 116-DR-9 \\
\hline Aroclor-1260 & 18-Feb-99 & B0TV42 & 140 & ug/kg & & 116-DR-9 \\
\hline Aroclor-1260 & 18-Feb-99 & B0TV42 & 140 & $\mathrm{ug} / \mathrm{kg}$ & & 116-DR-9 \\
\hline Aroclor-1260 & 18-Feb-99 & B0TV42 & 140 & $\mathrm{ug} / \mathrm{kg}$ & & 116-DR-9 \\
\hline Aroclor-1260 & 18-Feb-99 & B0TV42 & 140 & $\mathrm{ug} / \mathrm{kg}$ & & 116-DR-9 \\
\hline Aroclor-1260 & 18-Feb-99 & B0TV42 & 140 & $\mathrm{ug} / \mathrm{kg}$ & & 116-DR-9 \\
\hline Aroclor-1260 & 18-Feb-99 & B0TV37 & 150 & $\mathrm{ug} / \mathrm{kg}$ & & 116-DR-9 \\
\hline Aroclor-1260 & 18-Feb-99 & B0TV37 & 150 & $\mathrm{ug} / \mathrm{kg}$ & & 116-DR-9 \\
\hline Aroclor-1260 & 18-Feb-99 & B0TV37 & 150 & $\mathrm{ug} / \mathrm{kg}$ & & 116-DR-9 \\
\hline Aroclor-1260 & 18-Feb-99 & B0TV37 & 150 & ug/kg & & 116-DR-9 \\
\hline Aroclor-1260 & 18-Feb-99 & B0TV37 & 150 & ug/kg & & 116-DR-9 \\
\hline Aroclor-1260 & 18-Feb-99 & B0TV39 & 160 & $\mathrm{ug} / \mathrm{kg}$ & & 116-DR-9 \\
\hline Aroclor-1260 & 18-Feb-99 & B0TV39 & 160 & $\mathrm{ug} / \mathrm{kg}$ & & 116-DR-9 \\
\hline Aroclor-1260 & 18-Feb-99 & B0TV39 & 160 & $\mathrm{ug} / \mathrm{kg}$ & & 116-DR-9 \\
\hline Aroclor-1260 & 18-Feb-99 & B0TV39 & 160 & $\mathrm{ug} / \mathrm{kg}$ & & 116-DR-9 \\
\hline Aroclor-1260 & 18-Feb-99 & B0TV39 & 160 & $\mathrm{ug} / \mathrm{kg}$ & & 116-DR-9 \\
\hline Aroclor-1260 & 18-Feb-99 & B0TV38 & 180 & $\mathrm{ug} / \mathrm{kg}$ & & 116-DR-9 \\
\hline Aroclor-1260 & 18-Feb-99 & B0TV38 & 180 & $\mathrm{ug} / \mathrm{kg}$ & & 116-DR-9 \\
\hline Aroclor-1260 & 18-Feb-99 & B0TV38 & 180 & $\mathrm{ug} / \mathrm{kg}$ & & 116-DR-9 \\
\hline Aroclor-1260 & 18-Feb-99 & B0TV38 & 180 & $\mathrm{ug} / \mathrm{kg}$ & & 116-DR-9 \\
\hline Aroclor-1260 & 18-Feb-99 & B0TV38 & 180 & $\mathrm{ug} / \mathrm{kg}$ & & 116-DR-9 \\
\hline Aroclor-1260 & 19-Dec-97 & B0MP36 & 780 & $\mathrm{ug} / \mathrm{kg}$ & & 116-DR-9 \\
\hline Aroclor-1016 & 23-Feb-98 & B0N6R5 & 1800 & $\mathrm{ug} / \mathrm{kg}$ & & 116-DR-9 \\
\hline Aroclor-1260 & 09-Sep-98 & B0PVJ5 & 2900 & $\mathrm{ug} / \mathrm{kg}$ & & 116-DR-9 \\
\hline Aroclor-1260 & 16-Sep-98 & B0PVJ1 & 3400 & $\mathrm{ug} / \mathrm{kg}$ & & 116-DR-9 \\
\hline
\end{tabular}




\begin{tabular}{|c|c|c|c|c|c|c|}
\hline Aroclor & $\begin{array}{c}\text { Sample } \\
\text { Date }\end{array}$ & $\begin{array}{l}\text { Sample } \\
\text { Number }\end{array}$ & Result & Units & Well Name & $\begin{array}{c}\text { Waste Site or } \\
\text { Well ID }\end{array}$ \\
\hline Aroclor-1260 & 23-Feb-98 & B0N6R5 & 6900 & $\mathrm{ug} / \mathrm{kg}$ & & 116-DR-9 \\
\hline Aroclor-1260 & 21-Aug-00 & B10183 & 48 & $\mathrm{ug} / \mathrm{kg}$ & & $116-F-14$ \\
\hline Aroclor-1254 & 12-Dec-06 & J13W05 & 19 & $\mathrm{ug} / \mathrm{kg}$ & & 116-F-15 \\
\hline Aroclor-1254 & 12-Dec-06 & J13W10 & 25 & $\mathrm{ug} / \mathrm{kg}$ & & 116-F-15 \\
\hline Aroclor-1260 & 12-Dec-06 & J13W06 & 27 & $\mathrm{ug} / \mathrm{kg}$ & & 116-F-15 \\
\hline Aroclor-1260 & 12-Oct-04 & J01XR1 & 17 & $\mathrm{ug} / \mathrm{kg}$ & & 116-F-7 \\
\hline Aroclor-1254 & 10-Oct-01 & B13598 & 110 & ug/kg & & $116-F-9$ \\
\hline Aroclor-1254 & 14-Sep-00 & B10165 & 4300 & ug/kg & & $116-F-9$ \\
\hline Aroclor-1242 & 21-Oct-99 & B0WPB7 & 51 & $\mathrm{ug} / \mathrm{kg}$ & & $116-\mathrm{H}-21$ \\
\hline Aroclor-1260 & 21-Oct-99 & B0WPB7 & 110 & $\mathrm{ug} / \mathrm{kg}$ & & $116-\mathrm{H}-21$ \\
\hline Aroclor-1242 & 29-Sep-99 & BOWKJ2 & 55 & $\mathrm{ug} / \mathrm{kg}$ & & $116-\mathrm{H}-5$ \\
\hline Aroclor-1260 & 29-Sep-99 & BOWKJ2 & 220 & ug/kg & & $116-\mathrm{H}-5$ \\
\hline Aroclor-1242 & 29-Sep-99 & B0WKJ1 & 7400 & $\mathrm{ug} / \mathrm{kg}$ & & $116-\mathrm{H}-5$ \\
\hline Aroclor-1260 & 10-Feb-00 & B0XK38 & 33 & $\mathrm{ug} / \mathrm{kg}$ & & $116-\mathrm{H}-7$ \\
\hline Aroclor-1260 & 10-Aug-00 & BOYYP4 & 40 & $\mathrm{ug} / \mathrm{kg}$ & & $116-\mathrm{H}-7$ \\
\hline Aroclor-1260 & 10-Aug-00 & BOYYP4 & 40 & $\mathrm{ug} / \mathrm{kg}$ & & $116-\mathrm{H}-7$ \\
\hline Aroclor-1260 & $10-$ Aug-00 & BOYYP4 & 40 & $\mathrm{ug} / \mathrm{kg}$ & & $116-\mathrm{H}-7$ \\
\hline Aroclor-1260 & 10-Aug-00 & BOYYP4 & 40 & $\mathrm{ug} / \mathrm{kg}$ & & 116-H-7 \\
\hline Aroclor-1260 & 10-Aug-00 & BOYYP4 & 40 & $\mathrm{ug} / \mathrm{kg}$ & & $116-\mathrm{H}-7$ \\
\hline Aroclor-1242 & 11-Aug-00 & BOYYN6 & 43 & $\mathrm{ug} / \mathrm{kg}$ & & $116-\mathrm{H}-7$ \\
\hline Aroclor-1242 & 11-Aug-00 & BOYYN6 & 43 & $\mathrm{ug} / \mathrm{kg}$ & & $116-\mathrm{H}-7$ \\
\hline Aroclor-1242 & 11-Aug-00 & B0YYN6 & 43 & $\mathrm{ug} / \mathrm{kg}$ & & $116-\mathrm{H}-7$ \\
\hline Aroclor-1242 & 11-Aug-00 & BOYYN6 & 43 & $\mathrm{ug} / \mathrm{kg}$ & & $116-\mathrm{H}-7$ \\
\hline Aroclor-1242 & 11-Aug-00 & BOYYN6 & 43 & $\mathrm{ug} / \mathrm{kg}$ & & $116-\mathrm{H}-7$ \\
\hline Aroclor-1260 & 11-Aug-00 & BOYYN7 & 47 & $\mathrm{ug} / \mathrm{kg}$ & & $116-\mathrm{H}-7$ \\
\hline Aroclor-1260 & 11-Aug-00 & BOYYN7 & 47 & $\mathrm{ug} / \mathrm{kg}$ & & $116-\mathrm{H}-7$ \\
\hline Aroclor-1260 & 11-Aug-00 & BOYYN7 & 47 & $\mathrm{ug} / \mathrm{kg}$ & & $116-\mathrm{H}-7$ \\
\hline Aroclor-1260 & 11-Aug-00 & BOYYN7 & 47 & $\mathrm{ug} / \mathrm{kg}$ & & $116-\mathrm{H}-7$ \\
\hline Aroclor-1260 & 11-Aug-00 & BOYYN7 & 47 & $\mathrm{ug} / \mathrm{kg}$ & & $116-\mathrm{H}-7$ \\
\hline Aroclor-1260 & 10-Aug-00 & BOYYM9 & 48 & $\mathrm{ug} / \mathrm{kg}$ & & $116-\mathrm{H}-7$ \\
\hline Aroclor-1260 & $10-$ Aug-00 & BOYYM9 & 48 & $\mathrm{ug} / \mathrm{kg}$ & & $116-\mathrm{H}-7$ \\
\hline Aroclor-1260 & 10-Aug-00 & BOYYM9 & 48 & $\mathrm{ug} / \mathrm{kg}$ & & $116-\mathrm{H}-7$ \\
\hline Aroclor-1260 & 10-Aug-00 & BOYYM9 & 48 & $\mathrm{ug} / \mathrm{kg}$ & & $116-\mathrm{H}-7$ \\
\hline Aroclor-1260 & 10-Aug-00 & BOYYM9 & 48 & $\mathrm{ug} / \mathrm{kg}$ & & $116-\mathrm{H}-7$ \\
\hline Aroclor-1260 & 10-Aug-00 & BOYYN3 & 49 & $\mathrm{ug} / \mathrm{kg}$ & & $116-\mathrm{H}-7$ \\
\hline Aroclor-1260 & 10-Aug-00 & BOYYN3 & 49 & $\mathrm{ug} / \mathrm{kg}$ & & $116-\mathrm{H}-7$ \\
\hline Aroclor-1260 & 10-Aug-00 & BOYYN3 & 49 & $\mathrm{ug} / \mathrm{kg}$ & & $116-\mathrm{H}-7$ \\
\hline Aroclor-1260 & 10-Aug-00 & BOYYN3 & 49 & $\mathrm{ug} / \mathrm{kg}$ & & $116-\mathrm{H}-7$ \\
\hline
\end{tabular}




\begin{tabular}{|c|c|c|c|c|c|c|}
\hline Aroclor & $\begin{array}{l}\text { Sample } \\
\text { Date }\end{array}$ & $\begin{array}{l}\text { Sample } \\
\text { Number }\end{array}$ & Result & Units & Well Name & $\begin{array}{l}\text { Waste Site or } \\
\text { Well ID }\end{array}$ \\
\hline Aroclor-1260 & 10-Aug-00 & BOYYN3 & 49 & $\mathrm{ug} / \mathrm{kg}$ & & $116-\mathrm{H}-7$ \\
\hline Aroclor-1242 & 11-Aug-00 & BOYYN8 & 57 & $\mathrm{ug} / \mathrm{kg}$ & & 116-H-7 \\
\hline Aroclor-1242 & 11-Aug-00 & BOYYN8 & 57 & $\mathrm{ug} / \mathrm{kg}$ & & $116-\mathrm{H}-7$ \\
\hline Aroclor-1242 & 11-Aug-00 & BOYYN8 & 57 & $\mathrm{ug} / \mathrm{kg}$ & & 116-H-7 \\
\hline Aroclor-1242 & 11-Aug-00 & BOYYN8 & 57 & $\mathrm{ug} / \mathrm{kg}$ & & $116-\mathrm{H}-7$ \\
\hline Aroclor-1242 & 11-Aug-00 & BOYYN8 & 57 & $\mathrm{ug} / \mathrm{kg}$ & & $116-\mathrm{H}-7$ \\
\hline Aroclor-1242 & $10-$ Aug-00 & BOYYNO & 60 & $\mathrm{ug} / \mathrm{kg}$ & & $116-\mathrm{H}-7$ \\
\hline Aroclor-1242 & 10-Aug-00 & BOYYNO & 60 & $\mathrm{ug} / \mathrm{kg}$ & & $116-\mathrm{H}-7$ \\
\hline Aroclor-1242 & 10-Aug-00 & BOYYNO & 60 & $\mathrm{ug} / \mathrm{kg}$ & & $116-\mathrm{H}-7$ \\
\hline Aroclor-1242 & 10-Aug-00 & BOYYNO & 60 & $\mathrm{ug} / \mathrm{kg}$ & & $116-\mathrm{H}-7$ \\
\hline Aroclor-1242 & 10-Aug-00 & BOYYNO & 60 & $\mathrm{ug} / \mathrm{kg}$ & & $116-\mathrm{H}-7$ \\
\hline Aroclor-1260 & 23-Aug-00 & B101X3 & 76 & $\mathrm{ug} / \mathrm{kg}$ & & $116-\mathrm{H}-7$ \\
\hline Aroclor-1260 & 23-Aug-00 & B101X3 & 76 & $\mathrm{ug} / \mathrm{kg}$ & & $116-\mathrm{H}-7$ \\
\hline Aroclor-1260 & 23-Aug-00 & B101X3 & 76 & $\mathrm{ug} / \mathrm{kg}$ & & $116-\mathrm{H}-7$ \\
\hline Aroclor-1260 & 23-Aug-00 & B101X3 & 76 & $\mathrm{ug} / \mathrm{kg}$ & & $116-\mathrm{H}-7$ \\
\hline Aroclor-1260 & 23-Aug-00 & B101X1 & 85 & $\mathrm{ug} / \mathrm{kg}$ & & $116-\mathrm{H}-7$ \\
\hline Aroclor-1260 & 23-Aug-00 & B101X1 & 85 & $\mathrm{ug} / \mathrm{kg}$ & & $116-\mathrm{H}-7$ \\
\hline Aroclor-1260 & 23-Aug-00 & B101X1 & 85 & $\mathrm{ug} / \mathrm{kg}$ & & $116-\mathrm{H}-7$ \\
\hline Aroclor-1260 & 23-Aug-00 & B101X1 & 85 & $\mathrm{ug} / \mathrm{kg}$ & & $116-\mathrm{H}-7$ \\
\hline Aroclor-1260 & 11-Aug-00 & BOYYN6 & 88 & $\mathrm{ug} / \mathrm{kg}$ & & $116-\mathrm{H}-7$ \\
\hline Aroclor-1260 & 11-Aug-00 & BOYYN6 & 88 & $\mathrm{ug} / \mathrm{kg}$ & & 116-H-7 \\
\hline Aroclor-1260 & 11-Aug-00 & B0YYN6 & 88 & $\mathrm{ug} / \mathrm{kg}$ & & $116-\mathrm{H}-7$ \\
\hline Aroclor-1260 & 11-Aug-00 & BOYYN6 & 88 & $\mathrm{ug} / \mathrm{kg}$ & & $116-\mathrm{H}-7$ \\
\hline Aroclor-1260 & 11-Aug-00 & BOYYN6 & 88 & $\mathrm{ug} / \mathrm{kg}$ & & $116-\mathrm{H}-7$ \\
\hline Aroclor-1260 & 06-Nov-00 & B10NT5 & 95 & $\mathrm{ug} / \mathrm{kg}$ & & $116-\mathrm{H}-7$ \\
\hline Aroclor-1254 & $10-F e b-00$ & B0XK36 & 110 & ug/kg & & $116-\mathrm{H}-7$ \\
\hline Aroclor-1260 & 10-Aug-00 & BOYYNO & 120 & ug/kg & & $116-\mathrm{H}-7$ \\
\hline Aroclor-1260 & 10-Aug-00 & BOYYNO & 120 & $\mathrm{ug} / \mathrm{kg}$ & & $116-\mathrm{H}-7$ \\
\hline Aroclor-1260 & 10-Aug-00 & BOYYNO & 120 & $\mathrm{ug} / \mathrm{kg}$ & & $116-\mathrm{H}-7$ \\
\hline Aroclor-1260 & $10-$ Aug-00 & BOYYNO & 120 & $\mathrm{ug} / \mathrm{kg}$ & & $116-\mathrm{H}-7$ \\
\hline Aroclor-1260 & 10-Aug-00 & BOYYNO & 120 & $\mathrm{ug} / \mathrm{kg}$ & & $116-\mathrm{H}-7$ \\
\hline Aroclor-1260 & 11-Aug-00 & BOYYN8 & 140 & $\mathrm{ug} / \mathrm{kg}$ & & $116-\mathrm{H}-7$ \\
\hline Aroclor-1260 & 11-Aug-00 & BOYYN8 & 140 & $\mathrm{ug} / \mathrm{kg}$ & & $116-\mathrm{H}-7$ \\
\hline Aroclor-1260 & 11-Aug-00 & BOYYN8 & 140 & $\mathrm{ug} / \mathrm{kg}$ & & $116-\mathrm{H}-7$ \\
\hline Aroclor-1260 & 11-Aug-00 & BOYYN8 & 140 & $\mathrm{ug} / \mathrm{kg}$ & & $116-\mathrm{H}-7$ \\
\hline Aroclor-1260 & 11-Aug-00 & BOYYN8 & 140 & ug/kg & & $116-\mathrm{H}-7$ \\
\hline Aroclor-1260 & 19-Nov-99 & B0V6T2 & 160 & $\mathrm{ug} / \mathrm{kg}$ & & $116-\mathrm{H}-7$ \\
\hline Aroclor-1260 & 10-Feb-00 & B0XK37 & 170 & $\mathrm{ug} / \mathrm{kg}$ & & $116-\mathrm{H}-7$ \\
\hline
\end{tabular}




\begin{tabular}{|c|c|c|c|c|c|c|}
\hline Aroclor & $\begin{array}{c}\text { Sample } \\
\text { Date }\end{array}$ & $\begin{array}{l}\text { Sample } \\
\text { Number }\end{array}$ & Result & Units & Well Name & $\begin{array}{c}\text { Waste Site or } \\
\text { Well ID }\end{array}$ \\
\hline Aroclor-1242 & 10-Aug-00 & BOYYN4 & 230 & $\mathrm{ug} / \mathrm{kg}$ & & $116-\mathrm{H}-7$ \\
\hline Aroclor-1242 & 10-Aug-00 & BOYYN4 & 230 & $\mathrm{ug} / \mathrm{kg}$ & & $116-\mathrm{H}-7$ \\
\hline Aroclor-1242 & 10-Aug-00 & BOYYN4 & 230 & $\mathrm{ug} / \mathrm{kg}$ & & $116-\mathrm{H}-7$ \\
\hline Aroclor-1242 & 10-Aug-00 & BOYYN4 & 230 & $\mathrm{ug} / \mathrm{kg}$ & & $116-\mathrm{H}-7$ \\
\hline Aroclor-1242 & 10-Aug-00 & BOYYN4 & 230 & $\mathrm{ug} / \mathrm{kg}$ & & $116-\mathrm{H}-7$ \\
\hline Aroclor-1260 & 10-Aug-00 & BOYYN4 & 420 & $\mathrm{ug} / \mathrm{kg}$ & & $116-\mathrm{H}-7$ \\
\hline Aroclor-1260 & 10-Aug-00 & BOYYN4 & 420 & ug/kg & & $116-\mathrm{H}-7$ \\
\hline Aroclor-1260 & 10-Aug-00 & BOYYN4 & 420 & ug/kg & & $116-\mathrm{H}-7$ \\
\hline Aroclor-1260 & 10-Aug-00 & BOYYN4 & 420 & $\mathrm{ug} / \mathrm{kg}$ & & $116-\mathrm{H}-7$ \\
\hline Aroclor-1260 & 10-Aug-00 & BOYYN4 & 420 & $\mathrm{ug} / \mathrm{kg}$ & & $116-\mathrm{H}-7$ \\
\hline Aroclor-1260 & 11-Aug-00 & BOYYP2 & 560 & $\mathrm{ug} / \mathrm{kg}$ & & $116-\mathrm{H}-7$ \\
\hline Aroclor-1260 & 11-Aug-00 & BOYYP2 & 560 & ug/kg & & $116-\mathrm{H}-7$ \\
\hline Aroclor-1260 & 11-Aug-00 & BOYYP2 & 560 & $\mathrm{ug} / \mathrm{kg}$ & & $116-\mathrm{H}-7$ \\
\hline Aroclor-1260 & 11-Aug-00 & BOYYP2 & 560 & $\mathrm{ug} / \mathrm{kg}$ & & $116-\mathrm{H}-7$ \\
\hline Aroclor-1260 & 11-Aug-00 & B0YYP2 & 560 & $\mathrm{ug} / \mathrm{kg}$ & & $116-\mathrm{H}-7$ \\
\hline Aroclor-1260 & 06-Nov-00 & B10NT4 & 560 & $\mathrm{ug} / \mathrm{kg}$ & & $116-\mathrm{H}-7$ \\
\hline Aroclor-1260 & 11-Aug-00 & BOYYN5 & 660 & $\mathrm{ug} / \mathrm{kg}$ & & $116-\mathrm{H}-7$ \\
\hline Aroclor-1260 & 11-Aug-00 & B0YYN5 & 660 & $\mathrm{ug} / \mathrm{kg}$ & & $116-\mathrm{H}-7$ \\
\hline Aroclor-1260 & 11-Aug-00 & B0YYN5 & 660 & $\mathrm{ug} / \mathrm{kg}$ & & $116-\mathrm{H}-7$ \\
\hline Aroclor-1260 & 11-Aug-00 & B0YYN5 & 660 & $\mathrm{ug} / \mathrm{kg}$ & & $116-\mathrm{H}-7$ \\
\hline Aroclor-1260 & 11-Aug-00 & B0YYN5 & 660 & $\mathrm{ug} / \mathrm{kg}$ & & $116-\mathrm{H}-7$ \\
\hline Aroclor-1260 & 20-May-99 & BOVHJO & 1600 & ug/kg & & $116-\mathrm{H}-7$ \\
\hline Aroclor-1260 & 06-Nov-00 & B10NT6 & 2000 & $\mathrm{ug} / \mathrm{kg}$ & & $116-\mathrm{H}-7$ \\
\hline Aroclor-1260 & 14-Jun-99 & BOVLW4 & 5300 & $\mathrm{ug} / \mathrm{kg}$ & & $116-\mathrm{H}-7$ \\
\hline Aroclor-1248 & 04-Jun-99 & B0VLW6 & 6100 & $\mathrm{ug} / \mathrm{kg}$ & & $116-\mathrm{H}-7$ \\
\hline Aroclor-1260 & 04-Jun-99 & B0VLW1 & 8500 & ug/kg & & $116-\mathrm{H}-7$ \\
\hline Aroclor-1260 & 04-Jun-99 & B0VLW6 & 11000 & $\mathrm{ug} / \mathrm{kg}$ & & $116-\mathrm{H}-7$ \\
\hline Aroclor-1260 & 21-Jun-99 & B0VR11 & 17500 & $\mathrm{ug} / \mathrm{kg}$ & & $116-\mathrm{H}-7$ \\
\hline Aroclor-1260 & 19-Nov-99 & B0V6T3 & 64000 & $\mathrm{ug} / \mathrm{kg}$ & & $116-\mathrm{H}-7$ \\
\hline Aroclor-1260 & 24-Aug-00 & B10328 & 34 & $\mathrm{ug} / \mathrm{kg}$ & & $116-\mathrm{H}-7$ \\
\hline Aroclor-1260 & 24-Aug-00 & B10328 & 34 & $\mathrm{ug} / \mathrm{kg}$ & & $116-\mathrm{H}-7$ \\
\hline Aroclor-1260 & 24-Aug-00 & B10328 & 34 & $\mathrm{ug} / \mathrm{kg}$ & & $116-\mathrm{H}-7$ \\
\hline Aroclor-1260 & 24-Aug-00 & B10328 & 34 & $\mathrm{ug} / \mathrm{kg}$ & & $116-\mathrm{H}-7$ \\
\hline Aroclor-1260 & 24-Aug-00 & B10327 & 83.968 & $\mathrm{ug} / \mathrm{kg}$ & & $116-\mathrm{H}-7$ \\
\hline Aroclor-1260 & 24-Aug-00 & B10327 & 83.968 & $\mathrm{ug} / \mathrm{kg}$ & & $116-\mathrm{H}-7$ \\
\hline Aroclor-1260 & 24-Aug-00 & B10327 & 83.968 & $\mathrm{ug} / \mathrm{kg}$ & & $116-\mathrm{H}-7$ \\
\hline Aroclor-1260 & 24-Aug-00 & B10327 & 83.968 & $\mathrm{ug} / \mathrm{kg}$ & & $116-\mathrm{H}-7$ \\
\hline Aroclor-1260 & 24-Aug-00 & B10326 & 660 & $\mathrm{ug} / \mathrm{kg}$ & & $116-\mathrm{H}-7$ \\
\hline
\end{tabular}




\begin{tabular}{|c|c|c|c|c|c|c|}
\hline Aroclor & $\begin{array}{l}\text { Sample } \\
\text { Date }\end{array}$ & $\begin{array}{l}\text { Sample } \\
\text { Number }\end{array}$ & Result & Units & Well Name & $\begin{array}{l}\text { Waste Site or } \\
\text { Well ID }\end{array}$ \\
\hline Aroclor-1260 & 24-Aug-00 & B10326 & 660 & $\mathrm{ug} / \mathrm{kg}$ & & $116-\mathrm{H}-7$ \\
\hline Aroclor-1260 & 24-Aug-00 & B10326 & 660 & $\mathrm{ug} / \mathrm{kg}$ & & 116-H-7 \\
\hline Aroclor-1260 & 24-Aug-00 & B10326 & 660 & $\mathrm{ug} / \mathrm{kg}$ & & 116-H-7 \\
\hline Aroclor-1254 & 21-Jul-04 & J01MP3 & 16 & $\mathrm{ug} / \mathrm{kg}$ & & 118-B-1 \\
\hline Aroclor-1254 & 19-Oct-06 & J13J06 & 27 & $\mathrm{ug} / \mathrm{kg}$ & & 118-B-1 \\
\hline Aroclor-1254 & 19-Oct-06 & J13J06 & 27 & $\mathrm{ug} / \mathrm{kg}$ & & 118-B-1 \\
\hline Aroclor-1254 & 19-Oct-06 & J13J06 & 27 & $\mathrm{ug} / \mathrm{kg}$ & & 118-B-1 \\
\hline Aroclor-1254 & 19-Oct-06 & J13J06 & 27 & $\mathrm{ug} / \mathrm{kg}$ & & 118-B-1 \\
\hline Aroclor-1254 & 19-Oct-06 & J13J06 & 27 & $\mathrm{ug} / \mathrm{kg}$ & & 118-B-1 \\
\hline Aroclor-1242 & 17-Nov-05 & J10M46 & 34 & $\mathrm{ug} / \mathrm{kg}$ & & 118-B-1 \\
\hline Aroclor-1254 & 11-Jul-06 & J12WK6 & 38 & $\mathrm{ug} / \mathrm{kg}$ & & 118-B-1 \\
\hline Aroclor-1254 & 11-Jul-06 & J12WK6 & 38 & $\mathrm{ug} / \mathrm{kg}$ & & 118-B-1 \\
\hline Aroclor-1254 & 11-Jul-06 & J12WK6 & 38 & $\mathrm{ug} / \mathrm{kg}$ & & 118-B-1 \\
\hline Aroclor-1254 & 11-Jul-06 & J12WK6 & 38 & $\mathrm{ug} / \mathrm{kg}$ & & 118-B-1 \\
\hline Aroclor-1254 & 11-Jul-06 & J12WK6 & 38 & $\mathrm{ug} / \mathrm{kg}$ & & 118-B-1 \\
\hline Aroclor-1242 & 18-Oct-06 & J13J05 & 47 & $\mathrm{ug} / \mathrm{kg}$ & & 118-B-1 \\
\hline Aroclor-1242 & 18-Oct-06 & J13J05 & 47 & $\mathrm{ug} / \mathrm{kg}$ & & 118-B-1 \\
\hline Aroclor-1242 & 18-Oct-06 & J13J05 & 47 & $\mathrm{ug} / \mathrm{kg}$ & & 118-B-1 \\
\hline Aroclor-1242 & 18-Oct-06 & J13J05 & 47 & $\mathrm{ug} / \mathrm{kg}$ & & 118-B-1 \\
\hline Aroclor-1242 & 18-Oct-06 & J13J05 & 47 & $\mathrm{ug} / \mathrm{kg}$ & & 118-B-1 \\
\hline Aroclor-1254 & 12-Jul-06 & J12WW0 & 47 & $\mathrm{ug} / \mathrm{kg}$ & & 118-B-1 \\
\hline Aroclor-1254 & 12-Jul-06 & J12WW0 & 47 & $\mathrm{ug} / \mathrm{kg}$ & & 118-B-1 \\
\hline Aroclor-1254 & 12-Jul-06 & J12WW0 & 47 & $\mathrm{ug} / \mathrm{kg}$ & & 118-B-1 \\
\hline Aroclor-1254 & 12-Jul-06 & J12WW0 & 47 & $\mathrm{ug} / \mathrm{kg}$ & & 118-B-1 \\
\hline Aroclor-1254 & 12-Jul-06 & J12WW0 & 47 & $\mathrm{ug} / \mathrm{kg}$ & & 118-B-1 \\
\hline Aroclor-1260 & 18-Oct-06 & J13J05 & 56 & $\mathrm{ug} / \mathrm{kg}$ & & 118-B-1 \\
\hline Aroclor-1260 & 18-Oct-06 & J13J05 & 56 & $\mathrm{ug} / \mathrm{kg}$ & & 118-B-1 \\
\hline Aroclor-1260 & 18-Oct-06 & J13J05 & 56 & $\mathrm{ug} / \mathrm{kg}$ & & 118-B-1 \\
\hline Aroclor-1260 & 18-Oct-06 & J13J05 & 56 & $\mathrm{ug} / \mathrm{kg}$ & & 118-B-1 \\
\hline Aroclor-1260 & 18-Oct-06 & J13J05 & 56 & $\mathrm{ug} / \mathrm{kg}$ & & 118-B-1 \\
\hline Aroclor-1254 & 25-Jul-06 & J12X65 & 57 & $\mathrm{ug} / \mathrm{kg}$ & & 118-B-1 \\
\hline Aroclor-1254 & 25-Jul-06 & $\mathrm{J} 12 \times 65$ & 57 & $\mathrm{ug} / \mathrm{kg}$ & & 118-B-1 \\
\hline Aroclor-1254 & 25-Jul-06 & $\mathrm{J} 12 \times 65$ & 57 & $\mathrm{ug} / \mathrm{kg}$ & & 118-B-1 \\
\hline Aroclor-1254 & 25-Jul-06 & $\mathrm{J} 12 \times 65$ & 57 & $\mathrm{ug} / \mathrm{kg}$ & & 118-B-1 \\
\hline Aroclor-1254 & 25-Jul-06 & $\mathrm{J} 12 \times 65$ & 57 & $\mathrm{ug} / \mathrm{kg}$ & & 118-B-1 \\
\hline Aroclor-1254 & 28-Aug-04 & J01R86 & 67 & $\mathrm{ug} / \mathrm{kg}$ & & 118-B-1 \\
\hline Aroclor-1254 & 25-Jul-06 & $\mathrm{J} 12 \times 61$ & 80 & $\mathrm{ug} / \mathrm{kg}$ & & 118-B-1 \\
\hline Aroclor-1254 & 25-Jul-06 & $\mathrm{J} 12 \times 61$ & 80 & $\mathrm{ug} / \mathrm{kg}$ & & 118-B-1 \\
\hline
\end{tabular}




\begin{tabular}{|c|c|c|c|c|c|c|}
\hline Aroclor & $\begin{array}{c}\text { Sample } \\
\text { Date }\end{array}$ & $\begin{array}{l}\text { Sample } \\
\text { Number }\end{array}$ & Result & Units & Well Name & $\begin{array}{c}\text { Waste Site or } \\
\text { Well ID }\end{array}$ \\
\hline Aroclor-1254 & 25-Jul-06 & J12X61 & 80 & $\mathrm{ug} / \mathrm{kg}$ & & 118-B-1 \\
\hline Aroclor-1254 & 25-Jul-06 & $\mathrm{J} 12 \times 61$ & 80 & $\mathrm{ug} / \mathrm{kg}$ & & 118-B-1 \\
\hline Aroclor-1254 & 25-Jul-06 & $\mathrm{J} 12 \times 61$ & 80 & $\mathrm{ug} / \mathrm{kg}$ & & 118-B-1 \\
\hline Aroclor-1260 & 12-Jul-06 & J12WW0 & 130 & $\mathrm{ug} / \mathrm{kg}$ & & 118-B-1 \\
\hline Aroclor-1260 & 12-Jul-06 & J12WW0 & 130 & $\mathrm{ug} / \mathrm{kg}$ & & 118-B-1 \\
\hline Aroclor-1260 & 12-Jul-06 & J12WW0 & 130 & $\mathrm{ug} / \mathrm{kg}$ & & 118-B-1 \\
\hline Aroclor-1260 & 12-Jul-06 & J12WW0 & 130 & $\mathrm{ug} / \mathrm{kg}$ & & 118-B-1 \\
\hline Aroclor-1260 & 12-Jul-06 & J12WW0 & 130 & $\mathrm{ug} / \mathrm{kg}$ & & 118-B-1 \\
\hline Aroclor-1254 & 18-Oct-06 & J13J05 & 170 & $\mathrm{ug} / \mathrm{kg}$ & & 118-B-1 \\
\hline Aroclor-1254 & 18-Oct-06 & J13J05 & 170 & $\mathrm{ug} / \mathrm{kg}$ & & 118-B-1 \\
\hline Aroclor-1254 & 18-Oct-06 & J13J05 & 170 & $\mathrm{ug} / \mathrm{kg}$ & & 118-B-1 \\
\hline Aroclor-1254 & 18-Oct-06 & J13J05 & 170 & $\mathrm{ug} / \mathrm{kg}$ & & 118-B-1 \\
\hline Aroclor-1254 & 18-Oct-06 & J13J05 & 170 & $\mathrm{ug} / \mathrm{kg}$ & & 118-B-1 \\
\hline Aroclor-1254 & 18-Aug-04 & J01PT2 & 180 & $\mathrm{ug} / \mathrm{kg}$ & & 118-B-1 \\
\hline Aroclor-1254 & 17-Nov-05 & J10M46 & 220 & $\mathrm{ug} / \mathrm{kg}$ & & 118-B-1 \\
\hline Aroclor-1254 & 21-Aug-06 & $\mathrm{J} 13510$ & 14 & $\mathrm{ug} / \mathrm{kg}$ & & $118-C-1$ \\
\hline Aroclor-1254 & 21-Aug-06 & $\mathrm{J} 13510$ & 14 & $\mathrm{ug} / \mathrm{kg}$ & & $118-C-1$ \\
\hline Aroclor-1254 & 21-Aug-06 & $\mathrm{J} 13510$ & 14 & $\mathrm{ug} / \mathrm{kg}$ & & 118-C-1 \\
\hline Aroclor-1254 & 21-Aug-06 & $\mathrm{J} 13510$ & 14 & $\mathrm{ug} / \mathrm{kg}$ & & $118-C-1$ \\
\hline Aroclor-1254 & 21-Aug-06 & $\mathrm{J} 13510$ & 14 & $\mathrm{ug} / \mathrm{kg}$ & & $118-C-1$ \\
\hline Aroclor-1254 & 12-Sep-06 & J135P4 & 14 & $\mathrm{ug} / \mathrm{kg}$ & & $118-C-1$ \\
\hline Aroclor-1254 & 12-Sep-06 & J135P4 & 14 & $\mathrm{ug} / \mathrm{kg}$ & & $118-C-1$ \\
\hline Aroclor-1254 & 12-Sep-06 & J135P4 & 14 & $\mathrm{ug} / \mathrm{kg}$ & & $118-C-1$ \\
\hline Aroclor-1254 & 12-Sep-06 & J135P4 & 14 & $\mathrm{ug} / \mathrm{kg}$ & & $118-C-1$ \\
\hline Aroclor-1254 & 12-Sep-06 & J135P4 & 14 & $\mathrm{ug} / \mathrm{kg}$ & & $118-C-1$ \\
\hline Aroclor-1254 & 21-Aug-06 & $\mathrm{J} 13517$ & 16 & $\mathrm{ug} / \mathrm{kg}$ & & $118-C-1$ \\
\hline Aroclor-1254 & 21-Aug-06 & $\mathrm{J} 13517$ & 16 & $\mathrm{ug} / \mathrm{kg}$ & & $118-C-1$ \\
\hline Aroclor-1254 & 21-Aug-06 & J13517 & 16 & $\mathrm{ug} / \mathrm{kg}$ & & $118-C-1$ \\
\hline Aroclor-1254 & 21-Aug-06 & $\mathrm{J} 13517$ & 16 & $\mathrm{ug} / \mathrm{kg}$ & & $118-C-1$ \\
\hline Aroclor-1254 & 21-Aug-06 & $\mathrm{J} 13517$ & 16 & $\mathrm{ug} / \mathrm{kg}$ & & 118-C-1 \\
\hline Aroclor-1254 & 12-Sep-06 & J135P2 & 17 & $\mathrm{ug} / \mathrm{kg}$ & & $118-C-1$ \\
\hline Aroclor-1254 & 12-Sep-06 & J135P2 & 17 & $\mathrm{ug} / \mathrm{kg}$ & & $118-C-1$ \\
\hline Aroclor-1254 & 12-Sep-06 & J135P2 & 17 & $\mathrm{ug} / \mathrm{kg}$ & & $118-C-1$ \\
\hline Aroclor-1254 & 12-Sep-06 & J135P2 & 17 & $\mathrm{ug} / \mathrm{kg}$ & & $118-C-1$ \\
\hline Aroclor-1254 & 12-Sep-06 & J135P2 & 17 & $\mathrm{ug} / \mathrm{kg}$ & & $118-C-1$ \\
\hline Aroclor-1254 & 12-Sep-06 & J135P6 & 20 & $\mathrm{ug} / \mathrm{kg}$ & & $118-C-1$ \\
\hline Aroclor-1254 & 12-Sep-06 & J135P6 & 20 & $\mathrm{ug} / \mathrm{kg}$ & & $118-C-1$ \\
\hline Aroclor-1254 & 12-Sep-06 & J135P6 & 20 & $\mathrm{ug} / \mathrm{kg}$ & & $118-C-1$ \\
\hline
\end{tabular}




\begin{tabular}{|c|c|c|c|c|c|c|}
\hline Aroclor & $\begin{array}{l}\text { Sample } \\
\text { Date }\end{array}$ & $\begin{array}{l}\text { Sample } \\
\text { Number }\end{array}$ & Result & Units & Well Name & $\begin{array}{l}\text { Waste Site or } \\
\text { Well ID }\end{array}$ \\
\hline Aroclor-1254 & 12-Sep-06 & J135P6 & 20 & $\mathrm{ug} / \mathrm{kg}$ & & $118-C-1$ \\
\hline Aroclor-1254 & 12-Sep-06 & J135P6 & 20 & $\mathrm{ug} / \mathrm{kg}$ & & 118-C-1 \\
\hline Aroclor-1254 & 21-Aug-06 & $\mathrm{J} 13513$ & 21 & $\mathrm{ug} / \mathrm{kg}$ & & $118-C-1$ \\
\hline Aroclor-1254 & 21-Aug-06 & $\mathrm{J} 13513$ & 21 & $\mathrm{ug} / \mathrm{kg}$ & & 118-C-1 \\
\hline Aroclor-1254 & 21-Aug-06 & $J 13513$ & 21 & $\mathrm{ug} / \mathrm{kg}$ & & $118-C-1$ \\
\hline Aroclor-1254 & 21-Aug-06 & $\mathrm{J} 13513$ & 21 & $\mathrm{ug} / \mathrm{kg}$ & & $118-C-1$ \\
\hline Aroclor-1254 & 21-Aug-06 & $\mathrm{J} 13513$ & 21 & $\mathrm{ug} / \mathrm{kg}$ & & $118-C-1$ \\
\hline Aroclor-1254 & 26-Jul-06 & J12XM2 & 22 & $\mathrm{ug} / \mathrm{kg}$ & & $118-\mathrm{C}-1$ \\
\hline Aroclor-1254 & 12-Sep-06 & J135P5 & 25 & $\mathrm{ug} / \mathrm{kg}$ & & $118-C-1$ \\
\hline Aroclor-1254 & 12-Sep-06 & J135P5 & 25 & $\mathrm{ug} / \mathrm{kg}$ & & $118-C-1$ \\
\hline Aroclor-1254 & 12-Sep-06 & J135P5 & 25 & $\mathrm{ug} / \mathrm{kg}$ & & $118-C-1$ \\
\hline Aroclor-1254 & 12-Sep-06 & J135P5 & 25 & $\mathrm{ug} / \mathrm{kg}$ & & $118-C-1$ \\
\hline Aroclor-1254 & 12-Sep-06 & J135P5 & 25 & $\mathrm{ug} / \mathrm{kg}$ & & $118-C-1$ \\
\hline Aroclor-1260 & 12-Sep-06 & J135P0 & 31 & $\mathrm{ug} / \mathrm{kg}$ & & $118-C-1$ \\
\hline Aroclor-1260 & 12-Sep-06 & J135P0 & 31 & $\mathrm{ug} / \mathrm{kg}$ & & $118-C-1$ \\
\hline Aroclor-1260 & 12-Sep-06 & J135P0 & 31 & $\mathrm{ug} / \mathrm{kg}$ & & $118-C-1$ \\
\hline Aroclor-1260 & 12-Sep-06 & J135P0 & 31 & $\mathrm{ug} / \mathrm{kg}$ & & $118-\mathrm{C}-1$ \\
\hline Aroclor-1260 & 12-Sep-06 & J135P0 & 31 & $\mathrm{ug} / \mathrm{kg}$ & & $118-C-1$ \\
\hline Aroclor-1254 & 21-Aug-06 & $J 13511$ & 46 & $\mathrm{ug} / \mathrm{kg}$ & & $118-C-1$ \\
\hline Aroclor-1254 & 21-Aug-06 & $J 13511$ & 46 & $\mathrm{ug} / \mathrm{kg}$ & & $118-C-1$ \\
\hline Aroclor-1254 & 21-Aug-06 & $\mathrm{J} 13511$ & 46 & $\mathrm{ug} / \mathrm{kg}$ & & 118-C-1 \\
\hline Aroclor-1254 & 21-Aug-06 & J13511 & 46 & $\mathrm{ug} / \mathrm{kg}$ & & 118-C-1 \\
\hline Aroclor-1254 & 21-Aug-06 & $J 13511$ & 46 & $\mathrm{ug} / \mathrm{kg}$ & & $118-C-1$ \\
\hline Aroclor-1260 & 11-Sep-06 & $J 13524$ & 61 & $\mathrm{ug} / \mathrm{kg}$ & & $118-C-1$ \\
\hline Aroclor-1260 & 11-Sep-06 & $J 13524$ & 61 & $\mathrm{ug} / \mathrm{kg}$ & & $118-C-1$ \\
\hline Aroclor-1260 & 11-Sep-06 & J13524 & 61 & ug/kg & & $118-C-1$ \\
\hline Aroclor-1260 & 11-Sep-06 & $J 13524$ & 61 & ug/kg & & $118-C-1$ \\
\hline Aroclor-1260 & 11-Sep-06 & J13524 & 61 & $\mathrm{ug} / \mathrm{kg}$ & & $118-C-1$ \\
\hline Aroclor-1254 & 21-Aug-06 & $\mathrm{J} 13512$ & 62 & $\mathrm{ug} / \mathrm{kg}$ & & $118-C-1$ \\
\hline Aroclor-1254 & 21-Aug-06 & $\mathrm{J} 13512$ & 62 & $\mathrm{ug} / \mathrm{kg}$ & & $118-\mathrm{C}-1$ \\
\hline Aroclor-1254 & 21-Aug-06 & $\mathrm{J} 13512$ & 62 & $\mathrm{ug} / \mathrm{kg}$ & & 118-C-1 \\
\hline Aroclor-1254 & 21-Aug-06 & $\mathrm{J} 13512$ & 62 & $\mathrm{ug} / \mathrm{kg}$ & & $118-C-1$ \\
\hline Aroclor-1254 & 21-Aug-06 & $\mathrm{J} 13512$ & 62 & $\mathrm{ug} / \mathrm{kg}$ & & $118-C-1$ \\
\hline Aroclor-1254 & 16-May-03 & J00NV3 & 29 & $\mathrm{ug} / \mathrm{kg}$ & & 118-D-6 \\
\hline Aroclor-1254 & 16-May-03 & JOONV2 & 34 & $\mathrm{ug} / \mathrm{kg}$ & & 118-D-6 \\
\hline Aroclor-1254 & 16-May-03 & J00NV5 & 77 & ug/kg & & 118-D-6 \\
\hline Aroclor-1254 & 16-May-03 & J00NV1 & 130 & $\mathrm{ug} / \mathrm{kg}$ & & 118-D-6 \\
\hline Aroclor-1260 & 28-Jul-00 & BOYRY4 & 46.44 & $\mathrm{ug} / \mathrm{kg}$ & & 118-DR-2:2 \\
\hline
\end{tabular}




\begin{tabular}{|c|c|c|c|c|c|c|}
\hline Aroclor & $\begin{array}{l}\text { Sample } \\
\text { Date }\end{array}$ & $\begin{array}{l}\text { Sample } \\
\text { Number }\end{array}$ & Result & Units & Well Name & $\begin{array}{l}\text { Waste Site or } \\
\text { Well ID }\end{array}$ \\
\hline Aroclor-1260 & 28-Jul-00 & BOYNH8 & 59.03 & $\mathrm{ug} / \mathrm{kg}$ & & 118-DR-2:2 \\
\hline Aroclor-1260 & 28-Jul-00 & BOYNJ7 & 172.409 & $\mathrm{ug} / \mathrm{kg}$ & & 118-DR-2:2 \\
\hline Aroclor-1260 & 28-Jul-00 & BOYNH9 & 202.736 & $\mathrm{ug} / \mathrm{kg}$ & & 118-DR-2:2 \\
\hline Aroclor-1260 & 28-Jul-00 & B0YNJ3 & 220.315 & $\mathrm{ug} / \mathrm{kg}$ & & 118-DR-2:2 \\
\hline Aroclor-1260 & 28-Jul-00 & BOYNJO & 261.97 & $\mathrm{ug} / \mathrm{kg}$ & & 118-DR-2:2 \\
\hline Aroclor-1260 & 28-Jul-00 & B0YNJ4 & 301.71 & $\mathrm{ug} / \mathrm{kg}$ & & 118-DR-2:2 \\
\hline Aroclor-1260 & 28-Jul-00 & B0YNJ1 & 302.487 & $\mathrm{ug} / \mathrm{kg}$ & & 118-DR-2:2 \\
\hline Aroclor-1260 & 28-Jul-00 & B0YNJ6 & 345.154 & $\mathrm{ug} / \mathrm{kg}$ & & 118-DR-2:2 \\
\hline Aroclor-1260 & 28-Jul-00 & B0YNJ5 & 369.741 & $\mathrm{ug} / \mathrm{kg}$ & & 118-DR-2:2 \\
\hline Aroclor-1260 & 28-Jul-00 & BOYNKO & 397.323 & $\mathrm{ug} / \mathrm{kg}$ & & 118-DR-2:2 \\
\hline Aroclor-1260 & 28-Jul-00 & B0YRY5 & 444.937 & $\mathrm{ug} / \mathrm{kg}$ & & 118-DR-2:2 \\
\hline Aroclor-1260 & 28-Jul-00 & B0YRY3 & 447.125 & $\mathrm{ug} / \mathrm{kg}$ & & 118-DR-2:2 \\
\hline Aroclor-1260 & 28-Jul-00 & BOYNK1 & 558.905 & $\mathrm{ug} / \mathrm{kg}$ & & 118-DR-2:2 \\
\hline Aroclor-1260 & 28-Jul-00 & B0YNJ8 & 1148.95 & $\mathrm{ug} / \mathrm{kg}$ & & 118-DR-2:2 \\
\hline Aroclor-1260 & 28-Jul-00 & BOYNK3 & 1300 & ug/kg & & 118-DR-2:2 \\
\hline Aroclor-1260 & 28-Jul-00 & BOYNJ2 & 2065.01 & $\mathrm{ug} / \mathrm{kg}$ & & 118-DR-2:2 \\
\hline Aroclor-1248 & 24-Aug-00 & В100T9 & 42 & $\mathrm{ug} / \mathrm{kg}$ & & 118-F-8:1 \\
\hline Aroclor-1248 & 24-Aug-00 & B100V2 & 49 & $\mathrm{ug} / \mathrm{kg}$ & & 118-F-8:1 \\
\hline Aroclor-1254 & 05-Dec-02 & J00BJ8 & 59 & $\mathrm{ug} / \mathrm{kg}$ & & 118-F-8:1 \\
\hline Aroclor-1254 & 04-Dec-02 & J00BJ2 & 61 & $\mathrm{ug} / \mathrm{kg}$ & & 118-F-8:1 \\
\hline Aroclor-1254 & 04-Dec-02 & J00BJ0 & 72 & $\mathrm{ug} / \mathrm{kg}$ & & 118-F-8:1 \\
\hline Aroclor-1260 & 22-Aug-00 & B100W5 & 86 & $\mathrm{ug} / \mathrm{kg}$ & & 118-F-8:1 \\
\hline Aroclor-1254 & 05-Dec-02 & J00BJ6 & 100 & ug/kg & & 118-F-8:1 \\
\hline Aroclor-1260 & 22-Aug-00 & B100X5 & 110 & ug/kg & & 118-F-8:1 \\
\hline Aroclor-1260 & 22-Aug-00 & B100W2 & 160 & $\mathrm{ug} / \mathrm{kg}$ & & 118-F-8:1 \\
\hline Aroclor-1248 & 22-Aug-00 & B100W2 & 170 & $\mathrm{ug} / \mathrm{kg}$ & & 118-F-8:1 \\
\hline Aroclor-1260 & 22-Aug-00 & B100X0 & 270 & $\mathrm{ug} / \mathrm{kg}$ & & 118-F-8:1 \\
\hline Aroclor-1248 & 24-Aug-00 & B100V4 & 280 & $\mathrm{ug} / \mathrm{kg}$ & & 118-F-8:1 \\
\hline Aroclor-1260 & 22-Aug-00 & B100W3 & 350 & $\mathrm{ug} / \mathrm{kg}$ & & 118-F-8:1 \\
\hline Aroclor-1254 & 05-Dec-02 & J00BL2 & 380 & $\mathrm{ug} / \mathrm{kg}$ & & 118-F-8:1 \\
\hline Aroclor-1260 & 22-Aug-00 & B100X4 & 420 & $\mathrm{ug} / \mathrm{kg}$ & & 118-F-8:1 \\
\hline Aroclor-1260 & 22-Aug-00 & B100W6 & 570 & $\mathrm{ug} / \mathrm{kg}$ & & 118-F-8:1 \\
\hline Aroclor-1260 & 22-Aug-00 & B100X2 & 580 & $\mathrm{ug} / \mathrm{kg}$ & & 118-F-8:1 \\
\hline Aroclor-1248 & 30-Aug-00 & B100V5 & 880 & $\mathrm{ug} / \mathrm{kg}$ & & 118-F-8:1 \\
\hline Aroclor-1254 & 05-Dec-02 & J00BL3 & 1100 & $\mathrm{ug} / \mathrm{kg}$ & & 118-F-8:1 \\
\hline Aroclor-1260 & 22-Aug-00 & B100W8 & 1100 & $\mathrm{ug} / \mathrm{kg}$ & & 118-F-8:1 \\
\hline Aroclor-1260 & 24-Aug-00 & B101V5 & 62000 & $\mathrm{ug} / \mathrm{kg}$ & & 118-F-8:1 \\
\hline Aroclor-1260 & 04-Jun-07 & $\mathrm{J} 15516$ & 49 & $\mathrm{ug} / \mathrm{kg}$ & & 118-F-8:4 \\
\hline
\end{tabular}




\begin{tabular}{|c|c|c|c|c|c|c|}
\hline Aroclor & $\begin{array}{l}\text { Sample } \\
\text { Date }\end{array}$ & $\begin{array}{l}\text { Sample } \\
\text { Number }\end{array}$ & Result & Units & Well Name & $\begin{array}{c}\text { Waste Site or } \\
\text { Well ID }\end{array}$ \\
\hline Aroclor-1260 & 04-Jun-07 & J15516 & 49 & $\mathrm{ug} / \mathrm{kg}$ & & 118-F-8:4 \\
\hline Aroclor-1260 & 04-Jun-07 & J15516 & 49 & $\mathrm{ug} / \mathrm{kg}$ & & 118-F-8:4 \\
\hline Aroclor-1260 & 04-Jun-07 & $\mathrm{J} 15516$ & 49 & $\mathrm{ug} / \mathrm{kg}$ & & 118-F-8:4 \\
\hline Aroclor-1260 & 13-Jun-06 & J12N54 & 22 & $\mathrm{ug} / \mathrm{kg}$ & & 120-B-1 \\
\hline Aroclor-1260 & 13-Jun-06 & J12N53 & 70 & $\mathrm{ug} / \mathrm{kg}$ & & 120-B-1 \\
\hline Aroclor-1260 & 13-Jun-06 & J12N50 & 96 & $\mathrm{ug} / \mathrm{kg}$ & & 120-B-1 \\
\hline Aroclor-1260 & 13-Jun-06 & J12N49 & 170 & $\mathrm{ug} / \mathrm{kg}$ & & 120-B-1 \\
\hline Aroclor-1254 & 13-Jun-06 & J12NC1 & 1900 & $\mathrm{ug} / \mathrm{kg}$ & & 120-B-1 \\
\hline Aroclor-1260 & 13-Jun-06 & J12NC1 & 3600 & $\mathrm{ug} / \mathrm{kg}$ & & 120-B-1 \\
\hline Aroclor-1254 & 21-Aug-96 & BOHYS5 & 72 & $\mathrm{ug} / \mathrm{kg}$ & & 120-D-1 \\
\hline Aroclor-1260 & 17-Jan-95 & B0DMS9 & 94 & $\mathrm{ug} / \mathrm{kg}$ & & 120-D-1 \\
\hline Aroclor-1254 & 25-Aug-92 & B06D26 & 100 & $\mathrm{ug} / \mathrm{kg}$ & & 120-D-1 \\
\hline Aroclor-1254 & 27-Jan-95 & BODMTO & 150 & $\mathrm{ug} / \mathrm{kg}$ & & 120-D-1 \\
\hline Aroclor-1260 & 27-Jan-95 & BODMTO & 150 & ug/kg & & 120-D-1 \\
\hline Aroclor-1260 & 27-Jan-95 & B0DMR5 & 190 & ug/kg & & 120-D-1 \\
\hline Aroclor-1254 & 17-Jan-95 & B0DMS9 & 200 & $\mathrm{ug} / \mathrm{kg}$ & & 120-D-1 \\
\hline Aroclor-1254 & 27-Jan-95 & B0DMR5 & 320 & $\mathrm{ug} / \mathrm{kg}$ & & 120-D-1 \\
\hline Aroclor-1254 & 27-Jan-95 & B0DMR6 & 320 & $\mathrm{ug} / \mathrm{kg}$ & & 120-D-1 \\
\hline Aroclor-1260 & 17-Jan-95 & B0DMT5 & 360 & $\mathrm{ug} / \mathrm{kg}$ & & 120-D-1 \\
\hline Aroclor-1254 & 27-Jan-95 & B0DMT1 & 400 & $\mathrm{ug} / \mathrm{kg}$ & & 120-D-1 \\
\hline Aroclor-1260 & 27-Jan-95 & B0DMR6 & 460 & $\mathrm{ug} / \mathrm{kg}$ & & 120-D-1 \\
\hline Aroclor-1260 & 27-Jan-95 & B0DMT1 & 470 & $\mathrm{ug} / \mathrm{kg}$ & & 120-D-1 \\
\hline Aroclor-1254 & 17-Jan-95 & B0DMT5 & 480 & ug/kg & & 120-D-1 \\
\hline Aroclor-1260 & 17-Jan-95 & BODMT2 & 1800 & ug/kg & & 120-D-1 \\
\hline Aroclor-1254 & 17-Jan-95 & BODMX2 & 2000 & $\mathrm{ug} / \mathrm{kg}$ & & 120-D-1 \\
\hline Aroclor-1260 & 17-Jan-95 & BODMX2 & 2000 & $\mathrm{ug} / \mathrm{kg}$ & & 120-D-1 \\
\hline Aroclor-1254 & 17-Jan-95 & BODMT2 & 2300 & $\mathrm{ug} / \mathrm{kg}$ & & 120-D-1 \\
\hline Aroclor-1260 & 17-Jan-95 & B0DMR2 & 3800 & $\mathrm{ug} / \mathrm{kg}$ & & 120-D-1 \\
\hline Aroclor-1254 & 17-Jan-95 & B0DMR2 & 4700 & $\mathrm{ug} / \mathrm{kg}$ & & 120-D-1 \\
\hline Aroclor-1260 & 17-Jan-95 & B0DMT3 & 7500 & $\mathrm{ug} / \mathrm{kg}$ & & 120-D-1 \\
\hline Aroclor-1254 & 17-Jan-95 & B0DMT3 & 9800 & $\mathrm{ug} / \mathrm{kg}$ & & 120-D-1 \\
\hline Aroclor-1254 & 17-Jan-95 & B0DMX3 & 11000 & $\mathrm{ug} / \mathrm{kg}$ & & 120-D-1 \\
\hline Aroclor-1260 & 17-Jan-95 & B0DMX3 & 11000 & $\mathrm{ug} / \mathrm{kg}$ & & 120-D-1 \\
\hline Aroclor-1260 & 17-Jan-95 & B0DMR3 & 12000 & $\mathrm{ug} / \mathrm{kg}$ & & 120-D-1 \\
\hline Aroclor-1254 & 17-Jan-95 & B0DMR3 & 17000 & $\mathrm{ug} / \mathrm{kg}$ & & 120-D-1 \\
\hline Aroclor-1260 & 15-Apr-05 & J030P6 & 17 & $\mathrm{ug} / \mathrm{kg}$ & & 126-B-3 \\
\hline Aroclor-1260 & 09-Aug-05 & J03WF7 & 23 & $\mathrm{ug} / \mathrm{kg}$ & & 126-B-3 \\
\hline Aroclor-1260 & 09-Aug-05 & J03WF6 & 53 & $\mathrm{ug} / \mathrm{kg}$ & & 126-B-3 \\
\hline
\end{tabular}




\begin{tabular}{|c|c|c|c|c|c|c|}
\hline Aroclor & $\begin{array}{c}\text { Sample } \\
\text { Date }\end{array}$ & $\begin{array}{l}\text { Sample } \\
\text { Number }\end{array}$ & Result & Units & Well Name & $\begin{array}{c}\text { Waste Site or } \\
\text { Well ID }\end{array}$ \\
\hline Aroclor-1254 & 14-Dec-05 & J10VC1 & 35 & $\mathrm{ug} / \mathrm{kg}$ & & $126-F-2$ \\
\hline Aroclor-1260 & 18-Jul-05 & J03NL9 & 42 & $\mathrm{ug} / \mathrm{kg}$ & & $126-\mathrm{F}-2$ \\
\hline Aroclor-1254 & 14-Dec-05 & J10VC2 & 74 & $\mathrm{ug} / \mathrm{kg}$ & & $126-\mathrm{F}-2$ \\
\hline Aroclor-1254 & 18-Jul-05 & J03NL8 & 85 & $\mathrm{ug} / \mathrm{kg}$ & & $126-\mathrm{F}-2$ \\
\hline Aroclor-1254 & 18-Jul-05 & J03NL7 & 140 & $\mathrm{ug} / \mathrm{kg}$ & & $126-\mathrm{F}-2$ \\
\hline Aroclor-1254 & 18-Jul-05 & J03NL6 & 220 & $\mathrm{ug} / \mathrm{kg}$ & & $126-\mathrm{F}-2$ \\
\hline Aroclor-1254 & 08-Jun-05 & J03CF6 & 14 & $\mathrm{ug} / \mathrm{kg}$ & & 128-B-2 \\
\hline Aroclor-1254 & 08-Jun-05 & $\mathrm{J03CH} 2$ & 14 & $\mathrm{ug} / \mathrm{kg}$ & & 128-B-2 \\
\hline Aroclor-1254 & 08-Jun-05 & J03CD7 & 22 & $\mathrm{ug} / \mathrm{kg}$ & & 128-B-2 \\
\hline Aroclor-1254 & 08-Jun-05 & J03CF9 & 22 & $\mathrm{ug} / \mathrm{kg}$ & & 128-B-2 \\
\hline Aroclor-1254 & 23-Nov-04 & J023C3 & 64 & $\mathrm{ug} / \mathrm{kg}$ & & 128-B-2 \\
\hline Aroclor-1254 & 08-Jun-05 & J03CD0 & 89 & $\mathrm{ug} / \mathrm{kg}$ & & 128-B-2 \\
\hline Aroclor-1254 & 08-Jun-05 & J03CD1 & 98 & ug/kg & & 128-B-2 \\
\hline Aroclor-1254 & 08-Jun-05 & J03CD2 & 110 & $\mathrm{ug} / \mathrm{kg}$ & & 128-B-2 \\
\hline Aroclor-1254 & 08-Jun-05 & J03CD6 & 360 & $\mathrm{ug} / \mathrm{kg}$ & & $128-B-2$ \\
\hline Aroclor-1260 & 14-Aug-06 & $\mathrm{J} 13577$ & 6.5 & $\mathrm{ug} / \mathrm{kg}$ & & 128-B-3 \\
\hline Aroclor-1260 & 14-Aug-06 & $\mathrm{J} 13554$ & 11 & $\mathrm{ug} / \mathrm{kg}$ & & 128-B-3 \\
\hline Aroclor-1254 & 14-Aug-06 & $\mathrm{J} 13557$ & 15 & $\mathrm{ug} / \mathrm{kg}$ & & 128-B-3 \\
\hline Aroclor-1254 & 13-Feb-06 & $\mathrm{J} 11819$ & 16 & $\mathrm{ug} / \mathrm{kg}$ & & 128-B-3 \\
\hline Aroclor-1254 & 13-Feb-06 & $\mathrm{J} 11821$ & 19 & $\mathrm{ug} / \mathrm{kg}$ & & $128-B-3$ \\
\hline Aroclor-1260 & 14-Aug-06 & $\mathrm{J} 13563$ & 19 & $\mathrm{ug} / \mathrm{kg}$ & & 128-B-3 \\
\hline Aroclor-1260 & 14-Aug-06 & $\mathrm{J} 13556$ & 20 & $\mathrm{ug} / \mathrm{kg}$ & & 128-B-3 \\
\hline Aroclor-1254 & 14-Aug-06 & $\mathrm{J} 13566$ & 25 & $\mathrm{ug} / \mathrm{kg}$ & & 128-B-3 \\
\hline Aroclor-1254 & 14-Aug-06 & $\mathrm{J} 13561$ & 27 & $\mathrm{ug} / \mathrm{kg}$ & & 128-B-3 \\
\hline Aroclor-1254 & 14-Aug-06 & $J 13565$ & 28 & $\mathrm{ug} / \mathrm{kg}$ & & 128-B-3 \\
\hline Aroclor-1254 & 14-Aug-06 & $\mathrm{J} 13577$ & 28 & $\mathrm{ug} / \mathrm{kg}$ & & 128-B-3 \\
\hline Aroclor-1260 & 14-Aug-06 & $\mathrm{J} 13558$ & 29 & $\mathrm{ug} / \mathrm{kg}$ & & 128-B-3 \\
\hline Aroclor-1254 & 05-Jul-06 & J12P09 & 32 & $\mathrm{ug} / \mathrm{kg}$ & & 128-B-3 \\
\hline Aroclor-1260 & 14-Aug-06 & $\mathrm{J} 13553$ & 33 & $\mathrm{ug} / \mathrm{kg}$ & & 128-B-3 \\
\hline Aroclor-1254 & 05-Jul-06 & $\mathrm{J} 12 \mathrm{P} 27$ & 36 & $\mathrm{ug} / \mathrm{kg}$ & & 128-B-3 \\
\hline Aroclor-1260 & 14-Aug-06 & $\mathrm{J} 13560$ & 36 & $\mathrm{ug} / \mathrm{kg}$ & & 128-B-3 \\
\hline Aroclor-1254 & 14-Aug-06 & $\mathrm{J} 13580$ & 43 & $\mathrm{ug} / \mathrm{kg}$ & & 128-B-3 \\
\hline Aroclor-1260 & 14-Aug-06 & $\mathrm{J} 13555$ & 55 & $\mathrm{ug} / \mathrm{kg}$ & & 128-B-3 \\
\hline Aroclor-1254 & 14-Aug-06 & $\mathrm{J} 13554$ & 71 & $\mathrm{ug} / \mathrm{kg}$ & & $128-B-3$ \\
\hline Aroclor-1254 & 14-Aug-06 & $\mathrm{J} 13556$ & 120 & $\mathrm{ug} / \mathrm{kg}$ & & 128-B-3 \\
\hline Aroclor-1254 & 14-Aug-06 & $\mathrm{J} 13563$ & 120 & $\mathrm{ug} / \mathrm{kg}$ & & 128-B-3 \\
\hline Aroclor-1254 & 14-Aug-06 & $\mathrm{J} 13558$ & 140 & $\mathrm{ug} / \mathrm{kg}$ & & 128-B-3 \\
\hline Aroclor-1254 & 05-Jul-06 & $\mathrm{J} 12 \mathrm{P} 15$ & 160 & $\mathrm{ug} / \mathrm{kg}$ & & 128-B-3 \\
\hline
\end{tabular}




\begin{tabular}{|c|c|c|c|c|c|c|}
\hline Aroclor & $\begin{array}{l}\text { Sample } \\
\text { Date }\end{array}$ & $\begin{array}{l}\text { Sample } \\
\text { Number }\end{array}$ & Result & Units & Well Name & $\begin{array}{l}\text { Waste Site or } \\
\text { Well ID }\end{array}$ \\
\hline Aroclor-1254 & 13-Feb-06 & $\mathrm{J} 11820$ & 170 & $\mathrm{ug} / \mathrm{kg}$ & & 128-B-3 \\
\hline Aroclor-1254 & 14-Aug-06 & J13560 & 170 & ug/kg & & 128-B-3 \\
\hline Aroclor-1254 & 14-Aug-06 & $\mathrm{J} 13553$ & 180 & $\mathrm{ug} / \mathrm{kg}$ & & 128-B-3 \\
\hline Aroclor-1254 & 05-Jul-06 & J12P05 & 190 & $\mathrm{ug} / \mathrm{kg}$ & & $128-B-3$ \\
\hline Aroclor-1254 & 14-Aug-06 & J13555 & 260 & $\mathrm{ug} / \mathrm{kg}$ & & $128-B-3$ \\
\hline Aroclor-1254 & 02-Feb-05 & J02FM9 & 26 & $\mathrm{ug} / \mathrm{kg}$ & & $128-C-1$ \\
\hline Aroclor-1254 & 02-Feb-05 & $\mathrm{J} 02 \mathrm{H} 65$ & 26 & $\mathrm{ug} / \mathrm{kg}$ & & $128-C-1$ \\
\hline Aroclor-1254 & 02-Feb-05 & J02FM6 & 31 & $\mathrm{ug} / \mathrm{kg}$ & & $128-C-1$ \\
\hline Aroclor-1254 & 02-Feb-05 & $\mathrm{J} 02 \mathrm{H} 63$ & 540 & $\mathrm{ug} / \mathrm{kg}$ & & $128-C-1$ \\
\hline Aroclor-1254 & 27-Oct-05 & J10D60 & 25 & $\mathrm{ug} / \mathrm{kg}$ & & 128-D-2 \\
\hline Aroclor-1260 & 26-Oct-05 & J10D61 & 68 & $\mathrm{ug} / \mathrm{kg}$ & & 128-D-2 \\
\hline Aroclor-1254 & 06-Mar-07 & J14L32 & 20 & $\mathrm{ug} / \mathrm{kg}$ & & 128-F-2 \\
\hline Aroclor-1260 & 01-Nov-06 & J13LX4 & 42 & $\mathrm{ug} / \mathrm{kg}$ & & $128-F-2$ \\
\hline Aroclor-1254 & 06-Mar-07 & J14L36 & 44 & $\mathrm{ug} / \mathrm{kg}$ & & $128-\mathrm{F}-2$ \\
\hline Aroclor-1254 & 21-Sep-05 & J107B2 & 89 & $\mathrm{ug} / \mathrm{kg}$ & & $128-\mathrm{F}-2$ \\
\hline Aroclor-1254 & 26-Oct-06 & J13LP2 & 110 & $\mathrm{ug} / \mathrm{kg}$ & & $128-F-2$ \\
\hline Aroclor-1254 & 07-Dec-04 & J024X2 & 940 & $\mathrm{ug} / \mathrm{kg}$ & & $128-\mathrm{F}-2$ \\
\hline Aroclor-1254 & 01-Apr-03 & J00KV4 & 35 & $\mathrm{ug} / \mathrm{kg}$ & & 1607-B10 \\
\hline Aroclor-1254 & 01-Apr-03 & J00KV4 & 35 & $\mathrm{ug} / \mathrm{kg}$ & & 1607-B10 \\
\hline Aroclor-1254 & 01-Apr-03 & J00KV4 & 35 & $\mathrm{ug} / \mathrm{kg}$ & & 1607-B10 \\
\hline Aroclor-1254 & 01-Apr-03 & J00KV4 & 35 & $\mathrm{ug} / \mathrm{kg}$ & & 1607-B10 \\
\hline Aroclor-1254 & 01-Apr-03 & J00KV4 & 35 & $\mathrm{ug} / \mathrm{kg}$ & & 1607-B10 \\
\hline Aroclor-1254 & 01-Apr-03 & J00KV6 & 57 & $\mathrm{ug} / \mathrm{kg}$ & & 1607-B10 \\
\hline Aroclor-1254 & 01-Apr-03 & J00KV6 & 57 & $\mathrm{ug} / \mathrm{kg}$ & & 1607-B10 \\
\hline Aroclor-1254 & 01-Apr-03 & J00KV6 & 57 & $\mathrm{ug} / \mathrm{kg}$ & & 1607-B10 \\
\hline Aroclor-1254 & 01-Apr-03 & J00KV6 & 57 & ug/kg & & 1607-B10 \\
\hline Aroclor-1254 & 01-Apr-03 & J00KV6 & 57 & ug/kg & & 1607-B10 \\
\hline Aroclor-1254 & 27-Jun-06 & J12NY9 & 4.4 & $\mathrm{ug} / \mathrm{kg}$ & & 1607-B2 \\
\hline Aroclor-1254 & 27-Jun-06 & J12NX5 & 6.2 & $\mathrm{ug} / \mathrm{kg}$ & & 1607-B2 \\
\hline Aroclor-1260 & 27-Jun-06 & $\mathrm{J} 12 \mathrm{NX} 8$ & 11 & $\mathrm{ug} / \mathrm{kg}$ & & 1607-B2 \\
\hline Aroclor-1254 & 27-Jun-06 & J12NY7 & 38 & $\mathrm{ug} / \mathrm{kg}$ & & 1607-B2 \\
\hline Aroclor-1254 & 27-Jun-06 & J12NY5 & 330 & $\mathrm{ug} / \mathrm{kg}$ & & 1607-B2 \\
\hline Aroclor-1254 & 31-Mar-03 & J00K37 & 62 & $\mathrm{ug} / \mathrm{kg}$ & & 1607-B8 \\
\hline Aroclor-1254 & 31-Mar-03 & J00K37 & 62 & $\mathrm{ug} / \mathrm{kg}$ & & 1607-B8 \\
\hline Aroclor-1254 & 31-Mar-03 & J00K37 & 62 & $\mathrm{ug} / \mathrm{kg}$ & & 1607-B8 \\
\hline Aroclor-1254 & 31-Mar-03 & J00K37 & 62 & $\mathrm{ug} / \mathrm{kg}$ & & 1607-B8 \\
\hline Aroclor-1254 & 31-Mar-03 & J00K37 & 62 & $\mathrm{ug} / \mathrm{kg}$ & & 1607-B8 \\
\hline Aroclor-1260 & 31-Mar-03 & J00KV2 & 68 & $\mathrm{ug} / \mathrm{kg}$ & & 1607-B8 \\
\hline
\end{tabular}




\begin{tabular}{|c|c|c|c|c|c|c|}
\hline Aroclor & $\begin{array}{l}\text { Sample } \\
\text { Date }\end{array}$ & $\begin{array}{l}\text { Sample } \\
\text { Number }\end{array}$ & Result & Units & Well Name & $\begin{array}{c}\text { Waste Site or } \\
\text { Well ID }\end{array}$ \\
\hline Aroclor-1260 & 31-Mar-03 & J00KV2 & 68 & $\mathrm{ug} / \mathrm{kg}$ & & 1607-B8 \\
\hline Aroclor-1260 & 31-Mar-03 & J00KV2 & 68 & ug/kg & & 1607-B8 \\
\hline Aroclor-1260 & 31-Mar-03 & J00KV2 & 68 & $\mathrm{ug} / \mathrm{kg}$ & & 1607-B8 \\
\hline Aroclor-1260 & 31-Mar-03 & J00KV2 & 68 & $\mathrm{ug} / \mathrm{kg}$ & & 1607-B8 \\
\hline Aroclor-1254 & 31-Mar-03 & J00K38 & 84 & $\mathrm{ug} / \mathrm{kg}$ & & 1607-B8 \\
\hline Aroclor-1254 & 31-Mar-03 & J00K38 & 84 & $\mathrm{ug} / \mathrm{kg}$ & & 1607-B8 \\
\hline Aroclor-1254 & 31-Mar-03 & J00K38 & 84 & $\mathrm{ug} / \mathrm{kg}$ & & 1607-B8 \\
\hline Aroclor-1254 & 31-Mar-03 & J00K38 & 84 & $\mathrm{ug} / \mathrm{kg}$ & & 1607-B8 \\
\hline Aroclor-1254 & 31-Mar-03 & J00K38 & 84 & $\mathrm{ug} / \mathrm{kg}$ & & 1607-B8 \\
\hline Aroclor-1254 & 31-Mar-03 & J00K39 & 84 & $\mathrm{ug} / \mathrm{kg}$ & & 1607-B8 \\
\hline Aroclor-1254 & 31-Mar-03 & J00K39 & 84 & $\mathrm{ug} / \mathrm{kg}$ & & 1607-B8 \\
\hline Aroclor-1254 & 31-Mar-03 & J00K39 & 84 & $\mathrm{ug} / \mathrm{kg}$ & & 1607-B8 \\
\hline Aroclor-1254 & 31-Mar-03 & J00K39 & 84 & $\mathrm{ug} / \mathrm{kg}$ & & 1607-B8 \\
\hline Aroclor-1254 & 31-Mar-03 & J00K39 & 84 & $\mathrm{ug} / \mathrm{kg}$ & & 1607-B8 \\
\hline Aroclor-1254 & 31-Mar-03 & J00K35 & 380 & $\mathrm{ug} / \mathrm{kg}$ & & 1607-B8 \\
\hline Aroclor-1254 & 31-Mar-03 & J00K35 & 380 & $\mathrm{ug} / \mathrm{kg}$ & & 1607-B8 \\
\hline Aroclor-1254 & 31-Mar-03 & J00K35 & 380 & $\mathrm{ug} / \mathrm{kg}$ & & 1607-B8 \\
\hline Aroclor-1254 & 31-Mar-03 & J00K35 & 380 & $\mathrm{ug} / \mathrm{kg}$ & & 1607-B8 \\
\hline Aroclor-1254 & 31-Mar-03 & J00K35 & 380 & $\mathrm{ug} / \mathrm{kg}$ & & 1607-B8 \\
\hline Aroclor-1254 & 14-Oct-03 & J010B7 & 14 & $\mathrm{ug} / \mathrm{kg}$ & & 1607-B9 \\
\hline Aroclor-1254 & 14-Oct-03 & J010B3 & 15 & $\mathrm{ug} / \mathrm{kg}$ & & 1607-B9 \\
\hline Aroclor-1254 & 03-Jan-06 & J10VK6 & 71 & $\mathrm{ug} / \mathrm{kg}$ & & 1607-D1 \\
\hline Aroclor-1260 & 04-Dec-97 & B0MK52 & 890 & $\mathrm{ug} / \mathrm{kg}$ & & 1607-D2 \\
\hline Aroclor-1260 & 04-Dec-97 & B0MK53 & 3400 & $\mathrm{ug} / \mathrm{kg}$ & & 1607-D2 \\
\hline Aroclor-1260 & 04-Dec-97 & B0MK54 & 3800 & $\mathrm{ug} / \mathrm{kg}$ & & 1607-D2 \\
\hline Aroclor-1260 & 04-Dec-97 & B0MK55 & 22000 & $\mathrm{ug} / \mathrm{kg}$ & & 1607-D2 \\
\hline Aroclor-1254 & 29-Sep-98 & B0PY52 & 3400 & ug/kg & & 1607-D2 \\
\hline Aroclor-1254 & 29-Sep-98 & B0PY53 & 12000 & $\mathrm{ug} / \mathrm{kg}$ & & 1607-D2 \\
\hline Aroclor-1254 & 22-Feb-01 & B11J64 & 170 & $\mathrm{ug} / \mathrm{kg}$ & & $1607-\mathrm{F} 2$ \\
\hline Aroclor-1260 & 06-Oct-04 & J01XJ3 & 51 & $\mathrm{ug} / \mathrm{kg}$ & & 1607-F3 \\
\hline Aroclor-1254 & 16-Jan-01 & B118D5 & 88 & $\mathrm{ug} / \mathrm{kg}$ & & 1607-F6 \\
\hline Aroclor-1254 & 16-Jan-01 & B118D5 & 88 & $\mathrm{ug} / \mathrm{kg}$ & & 1607-F6 \\
\hline Aroclor-1254 & 16-Jan-01 & B118D5 & 88 & $\mathrm{ug} / \mathrm{kg}$ & & $1607-\mathrm{F} 6$ \\
\hline Aroclor-1254 & 16-Jan-01 & B118D5 & 88 & $\mathrm{ug} / \mathrm{kg}$ & & $1607-\mathrm{F} 6$ \\
\hline Aroclor-1254 & 16-Jan-01 & B118D5 & 88 & $\mathrm{ug} / \mathrm{kg}$ & & $1607-\mathrm{F} 6$ \\
\hline Aroclor-1260 & 16-Jan-01 & B118D6 & 89 & ug/kg & & $1607-\mathrm{F} 6$ \\
\hline Aroclor-1260 & 16-Jan-01 & B118D6 & 89 & $\mathrm{ug} / \mathrm{kg}$ & & $1607-\mathrm{F} 6$ \\
\hline Aroclor-1260 & 16-Jan-01 & B118D6 & 89 & $\mathrm{ug} / \mathrm{kg}$ & & $1607-F 6$ \\
\hline
\end{tabular}




\begin{tabular}{|c|c|c|c|c|c|c|}
\hline Aroclor & $\begin{array}{c}\text { Sample } \\
\text { Date }\end{array}$ & $\begin{array}{l}\text { Sample } \\
\text { Number }\end{array}$ & Result & Units & Well Name & $\begin{array}{c}\text { Waste Site or } \\
\text { Well ID }\end{array}$ \\
\hline Aroclor-1260 & 16-Jan-01 & B118D6 & 89 & $\mathrm{ug} / \mathrm{kg}$ & & 1607-F6 \\
\hline Aroclor-1260 & 16-Jan-01 & B118D6 & 89 & $\mathrm{ug} / \mathrm{kg}$ & & 1607-F6 \\
\hline Aroclor-1254 & 16-Jan-01 & B118D1 & 240 & $\mathrm{ug} / \mathrm{kg}$ & & 1607-F6 \\
\hline Aroclor-1254 & 16-Jan-01 & B118D1 & 240 & $\mathrm{ug} / \mathrm{kg}$ & & $1607-\mathrm{F} 6$ \\
\hline Aroclor-1254 & 16-Jan-01 & B118D1 & 240 & $\mathrm{ug} / \mathrm{kg}$ & & 1607-F6 \\
\hline Aroclor-1254 & 16-Jan-01 & B118D1 & 240 & $\mathrm{ug} / \mathrm{kg}$ & & 1607-F6 \\
\hline Aroclor-1254 & 16-Jan-01 & B118D1 & 240 & $\mathrm{ug} / \mathrm{kg}$ & & 1607-F6 \\
\hline Aroclor-1254 & 16-Jan-01 & B118D2 & 410 & $\mathrm{ug} / \mathrm{kg}$ & & 1607-F6 \\
\hline Aroclor-1254 & 16-Jan-01 & B118D2 & 410 & $\mathrm{ug} / \mathrm{kg}$ & & $1607-\mathrm{F} 6$ \\
\hline Aroclor-1254 & 16-Jan-01 & B118D2 & 410 & $\mathrm{ug} / \mathrm{kg}$ & & $1607-\mathrm{F} 6$ \\
\hline Aroclor-1254 & 16-Jan-01 & B118D2 & 410 & $\mathrm{ug} / \mathrm{kg}$ & & $1607-\mathrm{F} 6$ \\
\hline Aroclor-1254 & 16-Jan-01 & B118D2 & 410 & ug/kg & & 1607-F6 \\
\hline Aroclor-1260 & 27-Jul-00 & B0YW33 & 3278.32 & $\mathrm{ug} / \mathrm{kg}$ & & $1607-\mathrm{F} 6$ \\
\hline Aroclor-1260 & 27-Jul-00 & B0YW34 & 53476.7 & $\mathrm{ug} / \mathrm{kg}$ & & $1607-\mathrm{F} 6$ \\
\hline Aroclor-1260 & 26-Apr-06 & J11VK3 & 60 & $\mathrm{ug} / \mathrm{kg}$ & & $1607-\mathrm{F} 7$ \\
\hline Aroclor-1254 & 01-Nov-99 & BowX62 & 34 & $\mathrm{ug} / \mathrm{kg}$ & & $1607-\mathrm{H} 2$ \\
\hline Aroclor-1254 & 04-Nov-99 & BoWXN1 & 85 & $\mathrm{ug} / \mathrm{kg}$ & & $1607-\mathrm{H} 2$ \\
\hline Aroclor-1254 & $16-F e b-00$ & B0X4R2 & 120 & $\mathrm{ug} / \mathrm{kg}$ & & $1607-\mathrm{H} 2$ \\
\hline Aroclor-1254 & 16-Feb-00 & B0X4R2 & 120 & $\mathrm{ug} / \mathrm{kg}$ & & $1607-\mathrm{H} 2$ \\
\hline Aroclor-1254 & 16-Feb-00 & B0X4R2 & 120 & $\mathrm{ug} / \mathrm{kg}$ & & $1607-\mathrm{H} 2$ \\
\hline Aroclor-1254 & $16-F e b-00$ & B0X4R2 & 120 & $\mathrm{ug} / \mathrm{kg}$ & & $1607-\mathrm{H} 2$ \\
\hline Aroclor-1254 & 16 -Feb-00 & B0X4R3 & 160 & $\mathrm{ug} / \mathrm{kg}$ & & $1607-\mathrm{H} 2$ \\
\hline Aroclor-1254 & $16-F e b-00$ & B0X4R3 & 160 & $\mathrm{ug} / \mathrm{kg}$ & & $1607-\mathrm{H} 2$ \\
\hline Aroclor-1254 & 16 -Feb-00 & B0X4R3 & 160 & $\mathrm{ug} / \mathrm{kg}$ & & $1607-\mathrm{H} 2$ \\
\hline Aroclor-1254 & $16-F e b-00$ & B0X4R3 & 160 & $\mathrm{ug} / \mathrm{kg}$ & & $1607-\mathrm{H} 2$ \\
\hline Aroclor-1260 & 29-Apr-05 & J03342 & 15 & $\mathrm{ug} / \mathrm{kg}$ & & $182 \mathrm{~F}$ \\
\hline Aroclor-1016 & 26-May-05 & $\mathrm{J} 03702$ & 20 & $\mathrm{ug} / \mathrm{kg}$ & & $182 \mathrm{~F}$ \\
\hline Aroclor-1016 & 26-May-05 & J03702 & 20 & $\mathrm{ug} / \mathrm{kg}$ & & $182 \mathrm{~F}$ \\
\hline Aroclor-1016 & 26-May-05 & $\mathrm{J} 03702$ & 20 & $\mathrm{ug} / \mathrm{kg}$ & & $182 \mathrm{~F}$ \\
\hline Aroclor-1016 & 26-May-05 & $\mathrm{J} 03702$ & 20 & $\mathrm{ug} / \mathrm{kg}$ & & $182 \mathrm{~F}$ \\
\hline Aroclor-1016 & 26-May-05 & $\mathrm{J} 03702$ & 20 & $\mathrm{ug} / \mathrm{kg}$ & & $182 \mathrm{~F}$ \\
\hline Aroclor-1254 & 26-May-05 & $\mathrm{J} 03702$ & 20 & $\mathrm{ug} / \mathrm{kg}$ & & $182 \mathrm{~F}$ \\
\hline Aroclor-1254 & 26-May-05 & J03702 & 20 & $\mathrm{ug} / \mathrm{kg}$ & & $182 \mathrm{~F}$ \\
\hline Aroclor-1254 & 26-May-05 & J03702 & 20 & $\mathrm{ug} / \mathrm{kg}$ & & $182 \mathrm{~F}$ \\
\hline Aroclor-1254 & 26-May-05 & J03702 & 20 & $\mathrm{ug} / \mathrm{kg}$ & & $182 \mathrm{~F}$ \\
\hline Aroclor-1254 & 26-May-05 & J03702 & 20 & $\mathrm{ug} / \mathrm{kg}$ & & $182 \mathrm{~F}$ \\
\hline Aroclor-1260 & 26-May-05 & J03704 & 23 & $\mathrm{ug} / \mathrm{kg}$ & & $182 \mathrm{~F}$ \\
\hline Aroclor-1260 & 26-May-05 & J03704 & 23 & $\mathrm{ug} / \mathrm{kg}$ & & $182 \mathrm{~F}$ \\
\hline
\end{tabular}




\begin{tabular}{|c|c|c|c|c|c|c|}
\hline Aroclor & $\begin{array}{c}\text { Sample } \\
\text { Date }\end{array}$ & $\begin{array}{l}\text { Sample } \\
\text { Number }\end{array}$ & Result & Units & Well Name & $\begin{array}{c}\text { Waste Site or } \\
\text { Well ID }\end{array}$ \\
\hline Aroclor-1260 & 26-May-05 & J03704 & 23 & $\mathrm{ug} / \mathrm{kg}$ & & $182 \mathrm{~F}$ \\
\hline Aroclor-1260 & 26-May-05 & $\mathrm{J} 03704$ & 23 & $\mathrm{ug} / \mathrm{kg}$ & & $182 \mathrm{~F}$ \\
\hline Aroclor-1260 & 26-May-05 & $\mathrm{J} 03704$ & 23 & $\mathrm{ug} / \mathrm{kg}$ & & $182 \mathrm{~F}$ \\
\hline Aroclor-1254 & 29-Apr-05 & $\mathrm{J} 03343$ & 36 & $\mathrm{ug} / \mathrm{kg}$ & & $182 \mathrm{~F}$ \\
\hline Aroclor-1260 & 12-Apr-05 & J030N6 & 36 & $\mathrm{ug} / \mathrm{kg}$ & & $182 \mathrm{~F}$ \\
\hline Aroclor-1260 & 12-Apr-05 & J030N7 & 41 & $\mathrm{ug} / \mathrm{kg}$ & & $182 \mathrm{~F}$ \\
\hline Aroclor-1254 & 26-May-05 & J03703 & 110 & $\mathrm{ug} / \mathrm{kg}$ & & $182 \mathrm{~F}$ \\
\hline Aroclor-1254 & 26-May-05 & J03703 & 110 & $\mathrm{ug} / \mathrm{kg}$ & & $182 \mathrm{~F}$ \\
\hline Aroclor-1254 & 26-May-05 & J03703 & 110 & $\mathrm{ug} / \mathrm{kg}$ & & $182 \mathrm{~F}$ \\
\hline Aroclor-1254 & 26-May-05 & J03703 & 110 & $\mathrm{ug} / \mathrm{kg}$ & & $182 \mathrm{~F}$ \\
\hline Aroclor-1254 & 26-May-05 & J03703 & 110 & $\mathrm{ug} / \mathrm{kg}$ & & $182 \mathrm{~F}$ \\
\hline Aroclor-1248 & 14-Aug-97 & B0L709 & 52 & $\mathrm{ug} / \mathrm{kg}$ & & 300 ASH PITS \\
\hline Aroclor-1260 & 22-Sep-97 & B0L946 & 86 & $\mathrm{ug} / \mathrm{kg}$ & & $300-45$ \\
\hline Aroclor-1260 & 25-Apr-06 & $\mathrm{J} 11 \mathrm{~J} \times 7$ & 21 & $\mathrm{ug} / \mathrm{kg}$ & & $300-49$ \\
\hline Aroclor-1260 & 25-Apr-06 & J11JX8 & 21 & $\mathrm{ug} / \mathrm{kg}$ & & $300-49$ \\
\hline Aroclor-1260 & 25-Apr-06 & J11JY0 & 23 & $\mathrm{ug} / \mathrm{kg}$ & & $300-49$ \\
\hline Aroclor-1254 & 25-Apr-06 & J11JX8 & 27 & $\mathrm{ug} / \mathrm{kg}$ & & $300-49$ \\
\hline Aroclor-1254 & 25-Apr-06 & J11JX7 & 30 & $\mathrm{ug} / \mathrm{kg}$ & & $300-49$ \\
\hline Aroclor-1254 & 25-Apr-06 & J11JY0 & 32 & $\mathrm{ug} / \mathrm{kg}$ & & $300-49$ \\
\hline Aroclor-1260 & 25-Apr-06 & J11JY1 & 34 & $\mathrm{ug} / \mathrm{kg}$ & & $300-49$ \\
\hline Aroclor-1260 & 25-Apr-06 & J11JX9 & 35 & $\mathrm{ug} / \mathrm{kg}$ & & $300-49$ \\
\hline Aroclor-1254 & 25-Apr-06 & J11JX9 & 36 & $\mathrm{ug} / \mathrm{kg}$ & & $300-49$ \\
\hline Aroclor-1254 & 25-Apr-06 & J11JY1 & 43 & $\mathrm{ug} / \mathrm{kg}$ & & $300-49$ \\
\hline Aroclor-1260 & 27-Mar-06 & J11928 & 23 & $\mathrm{ug} / \mathrm{kg}$ & & $300-7$ \\
\hline Aroclor-1260 & 27-Mar-06 & $\mathrm{J} 11930$ & 38 & $\mathrm{ug} / \mathrm{kg}$ & & $300-7$ \\
\hline Aroclor-1254 & 17-Dec-98 & B0R3R7 & 37 & $\mathrm{ug} / \mathrm{kg}$ & & $316-1$ \\
\hline Aroclor-1254 & 14-Jul-00 & B0YNN5 & 38 & $\mathrm{ug} / \mathrm{kg}$ & & $316-1$ \\
\hline Aroclor-1254 & 13-Jul-00 & BOYNM9 & 40.388 & $\mathrm{ug} / \mathrm{kg}$ & & $316-1$ \\
\hline Aroclor-1254 & 14-Jul-00 & BOYNN7 & 60 & $\mathrm{ug} / \mathrm{kg}$ & & $316-1$ \\
\hline Aroclor-1254 & 14-Jul-00 & BOYNN6 & 62 & $\mathrm{ug} / \mathrm{kg}$ & & $316-1$ \\
\hline Aroclor-1254 & 13-Jul-00 & B0YNM6 & 66.32 & $\mathrm{ug} / \mathrm{kg}$ & & $316-1$ \\
\hline Aroclor-1254 & 13-Jul-00 & B0YNM1 & 67.538 & $\mathrm{ug} / \mathrm{kg}$ & & $316-1$ \\
\hline Aroclor-1254 & 17-Dec-98 & B0R3R4 & 69 & $\mathrm{ug} / \mathrm{kg}$ & & $316-1$ \\
\hline Aroclor-1254 & 17-Dec-98 & B0R3T1 & 72 & $\mathrm{ug} / \mathrm{kg}$ & & $316-1$ \\
\hline Aroclor-1254 & 17-Dec-98 & B0R3R3 & 74 & $\mathrm{ug} / \mathrm{kg}$ & & $316-1$ \\
\hline Aroclor-1254 & 17-Dec-98 & B0R3R8 & 74 & $\mathrm{ug} / \mathrm{kg}$ & & $316-1$ \\
\hline Aroclor-1254 & 17-Dec-98 & B0R3T0 & 86 & $\mathrm{ug} / \mathrm{kg}$ & & $316-1$ \\
\hline Aroclor-1254 & 17-Dec-98 & B0R3R9 & 100 & $\mathrm{ug} / \mathrm{kg}$ & & $316-1$ \\
\hline
\end{tabular}




\begin{tabular}{|c|c|c|c|c|c|c|}
\hline Aroclor & $\begin{array}{l}\text { Sample } \\
\text { Date }\end{array}$ & $\begin{array}{l}\text { Sample } \\
\text { Number }\end{array}$ & Result & Units & Well Name & $\begin{array}{l}\text { Waste Site or } \\
\text { Well ID }\end{array}$ \\
\hline Aroclor-1248 & 06-Dec-91 & В00H84 & 110 & $\mathrm{ug} / \mathrm{kg}$ & & $316-1$ \\
\hline Aroclor-1254 & 17-Dec-98 & B0R3R5 & 110 & ug/kg & & $316-1$ \\
\hline Aroclor-1254 & 17-Dec-98 & B0R3R2 & 130 & ug/kg & & $316-1$ \\
\hline Aroclor-1254 & 17-Dec-98 & B0R3R1 & 160 & $\mathrm{ug} / \mathrm{kg}$ & & $316-1$ \\
\hline Aroclor-1254 & 17-Dec-98 & B0R3R6 & 180 & $\mathrm{ug} / \mathrm{kg}$ & & $316-1$ \\
\hline Aroclor-1254 & 13-Jul-00 & BOYNM2 & 188.074 & $\mathrm{ug} / \mathrm{kg}$ & & $316-1$ \\
\hline Aroclor-1254 & 02-Dec-91 & $\mathrm{B} 00 \mathrm{H} 60$ & 250 & $\mathrm{ug} / \mathrm{kg}$ & & $316-1$ \\
\hline Aroclor-1254 & 02-Dec-91 & В00H65 & 260 & $\mathrm{ug} / \mathrm{kg}$ & & $316-1$ \\
\hline Aroclor-1248 & 12-Sep-97 & B0L891 & 740 & $\mathrm{ug} / \mathrm{kg}$ & & $316-1$ \\
\hline Aroclor-1248 & 11-Sep-97 & B0L890 & 3000 & $\mathrm{ug} / \mathrm{kg}$ & & $316-1$ \\
\hline Aroclor-1254 & 11-Mar-99 & B0V1B0 & 100 & $\mathrm{ug} / \mathrm{kg}$ & & $316-2$ \\
\hline Aroclor-1254 & 14-Dec-91 & B01GF4 & 210 & $\mathrm{ug} / \mathrm{kg}$ & & $316-2$ \\
\hline Aroclor-1254 & 14-Dec-91 & B01GF6 & 230 & $\mathrm{ug} / \mathrm{kg}$ & & $316-2$ \\
\hline Aroclor-1254 & 12-Mar-99 & B0V033 & 40 & $\mathrm{ug} / \mathrm{kg}$ & & $316-5$ \\
\hline Aroclor-1254 & 12-Mar-99 & B0V032 & 42 & $\mathrm{ug} / \mathrm{kg}$ & & $316-5$ \\
\hline Aroclor-1260 & 12-Mar-99 & B0V031 & 110 & $\mathrm{ug} / \mathrm{kg}$ & & $316-5$ \\
\hline Aroclor-1248 & 12-Mar-99 & B0V031 & 460 & $\mathrm{ug} / \mathrm{kg}$ & & $316-5$ \\
\hline Aroclor-1248 & 12-Mar-99 & B0V034 & 500 & $\mathrm{ug} / \mathrm{kg}$ & & $316-5$ \\
\hline Aroclor-1248 & 12-Mar-99 & B0V035 & 590 & $\mathrm{ug} / \mathrm{kg}$ & & $316-5$ \\
\hline Aroclor-1248 & 12-Mar-99 & B0V030 & 870 & $\mathrm{ug} / \mathrm{kg}$ & & $316-5$ \\
\hline Aroclor-1254 & 31-Jul-91 & B01034 & 2800 & $\mathrm{ug} / \mathrm{kg}$ & & $316-5$ \\
\hline Aroclor-1260 & 31-Oct-05 & J10DM7 & 14 & $\mathrm{ug} / \mathrm{kg}$ & & $600-131$ \\
\hline Aroclor-1260 & 31-Oct-05 & J10DM8 & 20 & $\mathrm{ug} / \mathrm{kg}$ & & $600-131$ \\
\hline Aroclor-1260 & 31-Oct-05 & J10DM5 & 29 & $\mathrm{ug} / \mathrm{kg}$ & & $600-131$ \\
\hline Aroclor-1260 & 19-Apr-06 & J11K33 & 74 & $\mathrm{ug} / \mathrm{kg}$ & & $600-132$ \\
\hline Aroclor-1260 & 23-May-03 & J00P32 & 27 & $\mathrm{ug} / \mathrm{kg}$ & & $600-132$ \\
\hline Aroclor-1260 & 23-May-03 & J00P30 & 32 & $\mathrm{ug} / \mathrm{kg}$ & & $600-132$ \\
\hline Aroclor-1260 & 19-Apr-06 & J11K31 & 96 & $\mathrm{ug} / \mathrm{kg}$ & & $600-132$ \\
\hline Aroclor-1254 & 19-Apr-06 & $\mathrm{J} 11 \mathrm{~K} 33$ & 110 & $\mathrm{ug} / \mathrm{kg}$ & & $600-132$ \\
\hline Aroclor-1260 & 19-Apr-06 & $\mathrm{J} 11 \mathrm{~K} 30$ & 130 & $\mathrm{ug} / \mathrm{kg}$ & & $600-132$ \\
\hline Aroclor-1254 & 19-Apr-06 & J11K31 & 150 & $\mathrm{ug} / \mathrm{kg}$ & & $600-132$ \\
\hline Aroclor-1254 & 19-Apr-06 & $\mathrm{J} 11 \mathrm{~K} 30$ & 160 & $\mathrm{ug} / \mathrm{kg}$ & & $600-132$ \\
\hline Aroclor-1262 & 18-Apr-06 & J11K35 & 28 & $\mathrm{ug} / \mathrm{kg}$ & & $600-139$ \\
\hline Aroclor-1262 & 18-Apr-06 & J11K37 & 28 & $\mathrm{ug} / \mathrm{kg}$ & & $600-139$ \\
\hline Aroclor-1262 & 18-Apr-06 & J11K39 & 37 & $\mathrm{ug} / \mathrm{kg}$ & & $600-139$ \\
\hline Aroclor-1262 & 18-Apr-06 & J11K36 & 52 & $\mathrm{ug} / \mathrm{kg}$ & & $600-139$ \\
\hline Aroclor-1262 & 18-Apr-06 & $\mathrm{J} 11 \mathrm{~K} 38$ & 75 & $\mathrm{ug} / \mathrm{kg}$ & & $600-139$ \\
\hline Aroclor-1254 & 08-May-06 & J11K68 & 25 & $\mathrm{ug} / \mathrm{kg}$ & & $600-171$ \\
\hline
\end{tabular}




\begin{tabular}{|c|c|c|c|c|c|c|}
\hline Aroclor & $\begin{array}{l}\text { Sample } \\
\text { Date }\end{array}$ & $\begin{array}{l}\text { Sample } \\
\text { Number }\end{array}$ & Result & Units & Well Name & $\begin{array}{l}\text { Waste Site or } \\
\text { Well ID }\end{array}$ \\
\hline Aroclor-1254 & 20-Jun-06 & J12N84 & 170 & $\mathrm{ug} / \mathrm{kg}$ & & $600-171$ \\
\hline Aroclor-1254 & 23-May-06 & J11K24 & 17 & ug/kg & & $600-23$ \\
\hline Aroclor-1254 & 23-May-06 & J11K25 & 38 & $\mathrm{ug} / \mathrm{kg}$ & & $600-23$ \\
\hline Aroclor-1260 & 23-May-06 & J11K25 & 40 & $\mathrm{ug} / \mathrm{kg}$ & & $600-23$ \\
\hline Aroclor-1254 & 23-May-06 & J11K23 & 110 & $\mathrm{ug} / \mathrm{kg}$ & & $600-23$ \\
\hline Aroclor-1248 & 05-Jul-01 & B12BW8 & 590 & $\mathrm{ug} / \mathrm{kg}$ & & $600-23$ \\
\hline Aroclor-1254 & 18-Jul-01 & B12D73 & 1300 & $\mathrm{ug} / \mathrm{kg}$ & & $600-23$ \\
\hline Aroclor-1248 & 18-Jul-01 & B12D74 & 2000 & $\mathrm{ug} / \mathrm{kg}$ & & $600-23$ \\
\hline Aroclor-1248 & 05-Jul-01 & B12BW9 & 4700 & $\mathrm{ug} / \mathrm{kg}$ & & $600-23$ \\
\hline Aroclor-1254 & 27-Apr-04 & J01HB7 & 23 & $\mathrm{ug} / \mathrm{kg}$ & & $600-232$ \\
\hline Aroclor-1254 & 15-May-06 & J125L9 & 220 & $\mathrm{ug} / \mathrm{kg}$ & & $618-2$ \\
\hline Aroclor-1254 & 15-May-06 & $\mathrm{J} 125 \mathrm{~L} 7$ & 480 & $\mathrm{ug} / \mathrm{kg}$ & & $618-2$ \\
\hline Aroclor-1254 & 12-Feb-03 & $\mathrm{J} 00 \mathrm{H} 65$ & 42 & $\mathrm{ug} / \mathrm{kg}$ & & $618-4$ \\
\hline Aroclor-1260 & 04-Feb-92 & B01GP7 & 180 & $\mathrm{ug} / \mathrm{kg}$ & & $618-4$ \\
\hline Aroclor-1260 & 04-Feb-92 & B01GP6 & 220 & $\mathrm{ug} / \mathrm{kg}$ & & $618-4$ \\
\hline Aroclor-1260 & 04-Feb-92 & B01GP8 & 240 & $\mathrm{ug} / \mathrm{kg}$ & & $618-4$ \\
\hline Aroclor-1254 & 12-Feb-03 & $\mathrm{J0OH} 62$ & 800 & $\mathrm{ug} / \mathrm{kg}$ & & $618-4$ \\
\hline Aroclor-1254 & 12-Feb-03 & $\mathrm{J0OH} 64$ & 1100 & $\mathrm{ug} / \mathrm{kg}$ & & $618-4$ \\
\hline Aroclor-1254 & 12-Feb-03 & $\mathrm{J0OH} 63$ & 1600 & $\mathrm{ug} / \mathrm{kg}$ & & $618-4$ \\
\hline Aroclor-1254 & 28-Jun-00 & B0Y6M0 & 38.612 & $\mathrm{ug} / \mathrm{kg}$ & & $618-4$ \\
\hline Aroclor-1254 & 28-Jun-00 & B0Y6M3 & 38.906 & $\mathrm{ug} / \mathrm{kg}$ & & $618-4$ \\
\hline Aroclor-1254 & 28-Jun-00 & B0Y6M5 & 44.095 & $\mathrm{ug} / \mathrm{kg}$ & & 618-4 \\
\hline Aroclor-1254 & 28-Jun-00 & B0Y6M2 & 3007.72 & $\mathrm{ug} / \mathrm{kg}$ & & $618-4$ \\
\hline Aroclor-1254 & 05-Jul-00 & B0Y757 & 37.386 & $\mathrm{ug} / \mathrm{kg}$ & & $618-5$ \\
\hline Aroclor-1254 & 05-Jul-00 & B0Y745 & 43 & $\mathrm{ug} / \mathrm{kg}$ & & $618-5$ \\
\hline Aroclor-1254 & 05-Jul-00 & B0Y771 & 80.232 & $\mathrm{ug} / \mathrm{kg}$ & & $618-5$ \\
\hline Aroclor-1254 & 05-Jul-00 & B0Y759 & 108.119 & ug/kg & & $618-5$ \\
\hline Aroclor-1260 & 28-Jun-00 & B0Y755 & 134.83 & $\mathrm{ug} / \mathrm{kg}$ & & $618-5$ \\
\hline Aroclor-1260 & 28-Jun-00 & B0Y750 & 146.117 & $\mathrm{ug} / \mathrm{kg}$ & & $618-5$ \\
\hline Aroclor-1254 & 05-Jul-00 & B0Y772 & 176.792 & $\mathrm{ug} / \mathrm{kg}$ & & $618-5$ \\
\hline Aroclor-1260 & 28-Jun-00 & B0Y754 & 229.191 & $\mathrm{ug} / \mathrm{kg}$ & & $618-5$ \\
\hline Aroclor-1254 & 27-Jan-92 & B01GK6 & 68 & $\mathrm{ug} / \mathrm{kg}$ & & $618-5$ \\
\hline Aroclor-1016 & 28-May-91 & B00YC5 & 1900 & $\mathrm{ug} / \mathrm{kg}$ & & $618-9$ \\
\hline Aroclor-1221 & 28-May-91 & B00YC5 & 1900 & $\mathrm{ug} / \mathrm{kg}$ & & $618-9$ \\
\hline Aroclor-1232 & 28-May-91 & B00YC5 & 1900 & $\mathrm{ug} / \mathrm{kg}$ & & $618-9$ \\
\hline Aroclor-1242 & 28-May-91 & B00YC5 & 1900 & ug/kg & & $618-9$ \\
\hline Aroclor-1248 & 28-May-91 & B00YC5 & 1900 & $\mathrm{ug} / \mathrm{kg}$ & & $618-9$ \\
\hline Aroclor-1254 & 28-May-91 & B00YC5 & 3900 & $\mathrm{ug} / \mathrm{kg}$ & & $618-9$ \\
\hline
\end{tabular}




\begin{tabular}{|c|c|c|c|c|c|c|}
\hline Aroclor & $\begin{array}{l}\text { Sample } \\
\text { Date }\end{array}$ & $\begin{array}{l}\text { Sample } \\
\text { Number }\end{array}$ & Result & Units & Well Name & $\begin{array}{c}\text { Waste Site or } \\
\text { Well ID }\end{array}$ \\
\hline Aroclor-1260 & 28-May-91 & B00YC5 & 3900 & $\mathrm{ug} / \mathrm{kg}$ & & $618-9$ \\
\hline Aroclor-1254 & 24-Apr-06 & J11K66 & 33 & $\mathrm{ug} / \mathrm{kg}$ & & $628-1$ \\
\hline Aroclor-1260 & 13-Jul-00 & B0Y9W4 & 37.768 & $\mathrm{ug} / \mathrm{kg}$ & & $628-4$ \\
\hline Aroclor-1242 & 13-Jul-00 & B0Y9W3 & 42.354 & ug/kg & & $628-4$ \\
\hline Aroclor-1254 & 13-Jul-00 & B0Y9W2 & 44.347 & $\mathrm{ug} / \mathrm{kg}$ & & $628-4$ \\
\hline Aroclor-1242 & 13-Jul-00 & B0Y9V1 & 51 & $\mathrm{ug} / \mathrm{kg}$ & & $628-4$ \\
\hline Aroclor-1254 & 13-Jul-00 & B0Y9W3 & 67.367 & $\mathrm{ug} / \mathrm{kg}$ & & $628-4$ \\
\hline Aroclor-1254 & 13-Jul-00 & B0Y9V1 & 230 & $\mathrm{ug} / \mathrm{kg}$ & & $628-4$ \\
\hline Aroclor-1254 & 13-Jul-00 & B0Y9W7 & 275.177 & $\mathrm{ug} / \mathrm{kg}$ & & $628-4$ \\
\hline Aroclor-1254 & 13-Jul-00 & B0Y9W6 & 404.954 & $\mathrm{ug} / \mathrm{kg}$ & & $628-4$ \\
\hline Aroclor-1248 & 13-Jul-00 & B0Y9W5 & 1115.48 & $\mathrm{ug} / \mathrm{kg}$ & & $628-4$ \\
\hline Aroclor-1016 & 12-May-92 & B06M15 & 33 & $\mathrm{ug} / \mathrm{kg}$ & 199-K-37 & A4663 \\
\hline Aroclor-1232 & 12-May-92 & B06M15 & 33 & $\mathrm{ug} / \mathrm{kg}$ & $199-K-37$ & A4663 \\
\hline Aroclor-1242 & 12-May-92 & B06M15 & 33 & $\mathrm{ug} / \mathrm{kg}$ & $199-K-37$ & A4663 \\
\hline Aroclor-1248 & 12-May-92 & B06M15 & 33 & ug/kg & $199-K-37$ & A4663 \\
\hline Aroclor-1254 & 12-May-92 & B06M15 & 33 & $\mathrm{ug} / \mathrm{kg}$ & $199-K-37$ & A4663 \\
\hline Aroclor-1260 & 12-May-92 & B06M15 & 33 & $\mathrm{ug} / \mathrm{kg}$ & 199-K-37 & A4663 \\
\hline Aroclor-1016 & 14-May-92 & B06M16 & 34 & $\mathrm{ug} / \mathrm{kg}$ & 199-K-37 & A4663 \\
\hline Aroclor-1232 & 14-May-92 & B06M16 & 34 & $\mathrm{ug} / \mathrm{kg}$ & $199-K-37$ & A4663 \\
\hline Aroclor-1242 & 14-May-92 & B06M16 & 34 & $\mathrm{ug} / \mathrm{kg}$ & $199-K-37$ & A4663 \\
\hline Aroclor-1248 & 14-May-92 & B06M16 & 34 & $\mathrm{ug} / \mathrm{kg}$ & 199-K-37 & A4663 \\
\hline Aroclor-1254 & 14-May-92 & B06M16 & 34 & $\mathrm{ug} / \mathrm{kg}$ & $199-K-37$ & A4663 \\
\hline Aroclor-1260 & 14-May-92 & B06M16 & 34 & $\mathrm{ug} / \mathrm{kg}$ & $199-K-37$ & A4663 \\
\hline Aroclor-1016 & 18-May-92 & B06M17 & 39 & ug/kg & $199-K-37$ & A4663 \\
\hline Aroclor-1232 & 18-May-92 & B06M17 & 39 & $\mathrm{ug} / \mathrm{kg}$ & $199-K-37$ & A4663 \\
\hline Aroclor-1242 & 18-May-92 & B06M17 & 39 & $\mathrm{ug} / \mathrm{kg}$ & $199-K-37$ & A4663 \\
\hline Aroclor-1248 & 18-May-92 & B06M17 & 39 & $\mathrm{ug} / \mathrm{kg}$ & $199-K-37$ & A4663 \\
\hline Aroclor-1254 & 18-May-92 & B06M17 & 39 & $\mathrm{ug} / \mathrm{kg}$ & $199-K-37$ & A4663 \\
\hline Aroclor-1260 & 18-May-92 & B06M17 & 39 & $\mathrm{ug} / \mathrm{kg}$ & $199-K-37$ & A4663 \\
\hline Aroclor-1221 & 12-May-92 & B06M15 & 67 & $\mathrm{ug} / \mathrm{kg}$ & 199-K-37 & A4663 \\
\hline Aroclor-1221 & 14-May-92 & B06M16 & 68 & $\mathrm{ug} / \mathrm{kg}$ & 199-K-37 & A4663 \\
\hline Aroclor-1221 & 18-May-92 & B06M17 & 79 & $\mathrm{ug} / \mathrm{kg}$ & $199-K-37$ & A4663 \\
\hline Aroclor-1016 & 25-Jul-91 & B00YR9 & 78 & $\mathrm{ug} / \mathrm{kg}$ & 699-S22-E9B & A5423 \\
\hline Aroclor-1221 & 25-Jul-91 & B00YR9 & 78 & $\mathrm{ug} / \mathrm{kg}$ & 699-S22-E9B & A5423 \\
\hline Aroclor-1232 & 25-Jul-91 & B00YR9 & 78 & $\mathrm{ug} / \mathrm{kg}$ & 699-S22-E9B & A5423 \\
\hline Aroclor-1242 & 25-Jul-91 & B00YR9 & 78 & $\mathrm{ug} / \mathrm{kg}$ & 699-S22-E9B & A5423 \\
\hline Aroclor-1248 & 25-Jul-91 & B00YR9 & 78 & $\mathrm{ug} / \mathrm{kg}$ & 699-S22-E9B & A5423 \\
\hline Aroclor-1254 & 25-Jul-91 & B00YR9 & 160 & $\mathrm{ug} / \mathrm{kg}$ & 699-S22-E9B & A5423 \\
\hline
\end{tabular}




\begin{tabular}{|c|c|c|c|c|c|c|}
\hline Aroclor & $\begin{array}{c}\text { Sample } \\
\text { Date }\end{array}$ & $\begin{array}{l}\text { Sample } \\
\text { Number }\end{array}$ & Result & Units & Well Name & $\begin{array}{c}\text { Waste Site or } \\
\text { Well ID }\end{array}$ \\
\hline Aroclor-1260 & 25-Jul-91 & B00YR9 & 160 & $\mathrm{ug} / \mathrm{kg}$ & 699-S22-E9B & A5423 \\
\hline Aroclor-1016 & 25-Jul-91 & B00YQ0 & 81 & $\mathrm{ug} / \mathrm{kg}$ & 699-S27-E9B & A5426 \\
\hline Aroclor-1221 & 25-Jul-91 & BOOYQ0 & 81 & $\mathrm{ug} / \mathrm{kg}$ & 699-S27-E9B & A5426 \\
\hline Aroclor-1232 & 25-Jul-91 & BOOYQO & 81 & $\mathrm{ug} / \mathrm{kg}$ & 699-S27-E9B & A5426 \\
\hline Aroclor-1242 & 25-Jul-91 & BOOYQO & 81 & $\mathrm{ug} / \mathrm{kg}$ & 699-S27-E9B & A5426 \\
\hline Aroclor-1248 & 25-Jul-91 & BOOYQ0 & 81 & $\mathrm{ug} / \mathrm{kg}$ & 699-S27-E9B & A5426 \\
\hline Aroclor-1016 & 25-Jul-91 & B00YP8 & 85 & $\mathrm{ug} / \mathrm{kg}$ & 699-S27-E9B & A5426 \\
\hline Aroclor-1221 & 25-Jul-91 & B00YP8 & 85 & $\mathrm{ug} / \mathrm{kg}$ & 699-S27-E9B & A5426 \\
\hline Aroclor-1232 & 25-Jul-91 & B00YP8 & 85 & $\mathrm{ug} / \mathrm{kg}$ & 699-S27-E9B & A5426 \\
\hline Aroclor-1242 & 25-Jul-91 & B00YP8 & 85 & $\mathrm{ug} / \mathrm{kg}$ & 699-S27-E9B & A5426 \\
\hline Aroclor-1248 & 25-Jul-91 & B00YP8 & 85 & ug/kg & 699-S27-E9B & A5426 \\
\hline Aroclor-1254 & 25-Jul-91 & BOOYQ0 & 160 & $\mathrm{ug} / \mathrm{kg}$ & 699-S27-E9B & A5426 \\
\hline Aroclor-1260 & 25-Jul-91 & BOOYQO & 160 & $\mathrm{ug} / \mathrm{kg}$ & 699-S27-E9B & A5426 \\
\hline Aroclor-1254 & 25-Jul-91 & B00YP8 & 170 & $\mathrm{ug} / \mathrm{kg}$ & 699-S27-E9B & A5426 \\
\hline Aroclor-1260 & 25-Jul-91 & B00YP8 & 170 & $\mathrm{ug} / \mathrm{kg}$ & 699-S27-E9B & A5426 \\
\hline Aroclor-1254 & 08-Apr-93 & B085H8 & 460 & $\mathrm{ug} / \mathrm{kg}$ & $199-N-86$ & A5841 \\
\hline Aroclor-1254 & 02-Dec-91 & B015N1 & 340 & $\mathrm{ug} / \mathrm{kg}$ & 299-E33-310 & A7106 \\
\hline Aroclor-1254 & 23-Sep-91 & B014L2 & 210 & $\mathrm{ug} / \mathrm{kg}$ & $399-2-4$ & A8070 \\
\hline Aroclor-1248 & 03-Dec-91 & B01CC7 & 130 & $\mathrm{ug} / \mathrm{kg}$ & 399-3-16 & A8081 \\
\hline Aroclor-1248 & 25-Jan-90 & A2204 & 610 & $\mathrm{ug} / \mathrm{kg}$ & 699-S32-E9 & A9222 \\
\hline Aroclor-1248 & 25-Jan-90 & A2205 & 640 & $\mathrm{ug} / \mathrm{kg}$ & 699-S32-E9 & A9222 \\
\hline Aroclor-1254 & 10-Mar-94 & B09WI8 & 41 & ug/kg & 299-W23-231 & A9518 \\
\hline Aroclor-1260 & 10-Mar-94 & B09WI8 & 48 & $\mathrm{ug} / \mathrm{kg}$ & 299-W23-231 & A9518 \\
\hline Aroclor-1254 & 16-Nov-05 & J10DT2 & 23 & $\mathrm{ug} / \mathrm{kg}$ & & JA Jones \\
\hline Aroclor-1248 & 16-Nov-05 & J10DT3 & 28 & $\mathrm{ug} / \mathrm{kg}$ & & JA Jones \\
\hline Aroclor-1254 & 16-Nov-05 & J10DT0 & 30 & ug $/ \mathrm{kg}$ & & JA Jones \\
\hline Aroclor-1254 & 16-Nov-05 & J10DT1 & 30 & $\mathrm{ug} / \mathrm{kg}$ & & JA Jones \\
\hline Aroclor-1254 & 16-Nov-05 & J10DT4 & 32 & $\mathrm{ug} / \mathrm{kg}$ & & JA Jones \\
\hline Aroclor-1262 & 09-Oct-03 & SWMU1-9-2 & 25.6 & $\mathrm{ug} / \mathrm{kg}$ & & UPR-100-N-37 \\
\hline Aroclor-1262 & 09-Oct-03 & SWMU1-5-1 & 176 & $\mathrm{ug} / \mathrm{kg}$ & & UPR-100-N-37 \\
\hline
\end{tabular}




\section{APPENDIX D}

\section{EVALUATION OF PCB CONCENTRATIONS ESTIMATED IN 2004 SCULPIN}


WCH-208

Rev. 0 
APPENDIX D

\section{EVALUATION OF PCB CONCENTRATIONS ESTIMATED IN 2004 SCULPIN}

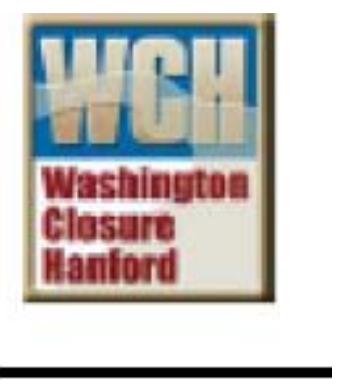

\section{Subject: 100 B/C Pilot Sculpin Sampling and Detection of PCBs}

Six fish tissue samples collected in August of 2004 as part of PNNL's Surface Environmental Surveillance Program (SESP) reported what appeared to be detectable levels of PCBS, as Aroclor-1254. Initial investigation of the data showed that these results were "E" qualified. Review of the Executive Summary of the 100-B/C Pilot Project Risk Assessment Report (DOE/RL-2005-40) revealed a direct address of the reported PCB detections for these samples:

"Aroclor-1254 results reported in whole sculpin tissue were flagged with an 'E' by the laboratory, indicating that the Aroclor congener did not match the Aroclor1254 standard with a high degree of confidence. Aroclor-1254 was not detected in sucker tissue. The risk estimates calculated using these results are considered overestimated; therefore, Aroclor-1254 is not considered a COC in whole sculpin tissue."

Analysis of total PCBs as Aroclors is difficult due to a finger-print matching technique that requires a high degree of interpretation on the part of the analyst and the tendency of Aroclors to degrade and become weathered in the environment. This distorts the chromatography making finger-print matching that much more challenging. Though the data integration software looks for programmed chromatographic characteristics unique to each Aroclor, these characteristics are limited and are based on 'clean' Aroclor standards. Determination of the presence or absence of Aroclors is up to the chemist and requires experienced/objective judgment.

Knowing these factors I tracked down the lab report submitted to PNNL, along with a QA narrative report. The language used to describe the qualification of the detections in question matched the language found in the executive summary. I followed this with a phone conversation with the chemist who analyzed the samples and discussed the reasoning for applying such a qualifier. She stated that she had a very low degree of confidence $(<25 \%)$ that the results were actually indicative of Aroclor-1254. When I asked if the results represented a weathered or degraded Aroclor-1254 she stated that her confidence level did not increase under that assumption. 
While the Aroclor-1254 results have a high degree of uncertainty, because they were reported they will be included in the risk assessment, with a caveat in the uncertainty section.

Author: Randy Hermann 


\section{APPENDIX E}

\section{PCB CONGENERS MOST ABUNDANT IN}

AROCLORS 1248, 1254, AND 1260 
WCH-208

Rev. 0 


\section{APPENDIX E}

\section{PCB CONGENERS MOST ABUNDANT IN AROCLORS 1248, 1254, AND 1260}

\begin{tabular}{|c|c|c|c|c|}
\hline \multirow{2}{*}{ Homologs } & \multirow{2}{*}{$\begin{array}{c}\text { TEF } \\
\text { Congeners }^{b}\end{array}$} & \multicolumn{3}{|c|}{ Congeners ${ }^{\mathrm{a}}$ Found in Aroclors at $\mathbf{0 . 9 \%}$ or Higher } \\
\hline & & Aroclor- 1248 & Aroclor- 1254 & Aroclor- 1260 \\
\hline Tri & & 17 & & \\
\hline Tri & & 18 & & \\
\hline Tri & & 22 & & \\
\hline Tri & & 28 & & \\
\hline Tri & & 31 & & \\
\hline Tri & & 32 & & \\
\hline Tri & & 33 & & \\
\hline Tri & & 37 & & \\
\hline Tetra & & 40 & & \\
\hline Tetra & & 42 & & \\
\hline Tetra & & 44 & 44 & \\
\hline Tetra & & 45 & & \\
\hline Tetra & & 47 & & \\
\hline Tetra & & 48 & & \\
\hline Tetra & & 49 & 49 & \\
\hline Tetra & & 52 & 52 & \\
\hline Tetra & & 56 & & \\
\hline Tetra & & 60 & & \\
\hline Tetra & & 64 & & \\
\hline Tetra & & 66 & 66 & \\
\hline Tetra & & 70 & 70 & \\
\hline Tetra & & 71 & & \\
\hline Tetra & & 74 & & \\
\hline Tetra & 77 & & & \\
\hline Tetra & 81 & & & \\
\hline Penta & & & 82 & \\
\hline
\end{tabular}




\begin{tabular}{|c|c|c|c|c|}
\hline \multirow{2}{*}{ Homologs } & \multirow{2}{*}{$\begin{array}{c}\text { TEF } \\
\text { Congeners }^{b}\end{array}$} & \multicolumn{3}{|c|}{ Congeners $^{\mathrm{a}}$ Found in Aroclors at $\mathbf{0 . 9 \%}$ or Higher } \\
\hline & & Aroclor- 1248 & Aroclor- 1254 & Aroclor- 1260 \\
\hline Penta & & 84 & 84 & \\
\hline Penta & & 85 & 85 & \\
\hline Penta & & 87 & 87 & \\
\hline Penta & & & 91 & \\
\hline Penta & & & 92 & \\
\hline Penta & & 95 & 95 & 95 \\
\hline Penta & & 97 & 97 & \\
\hline Penta & & 99 & 99 & \\
\hline Penta & & 101 & 101 & 101 \\
\hline Penta & 105 & 105 & 105 & \\
\hline Penta & & 110 & 110 & 110 \\
\hline Penta & 114 & & & \\
\hline Penta & 118 & 118 & 118 & \\
\hline Penta & 123 & & & \\
\hline Penta & 126 & & & \\
\hline Hexa & & & 128 & \\
\hline Hexa & & & 132 & 132 \\
\hline Hexa & & & & 135 \\
\hline Hexa & & & & 136 \\
\hline Hexa & & & 138 & 138 \\
\hline Hexa & & & 141 & 141 \\
\hline Hexa & & & & 146 \\
\hline Hexa & & & 149 & 149 \\
\hline Hexa & & & & 151 \\
\hline Hexa & & & 153 & 153 \\
\hline Hexa & 156 & & & \\
\hline Hexa & 157 & & & \\
\hline Hexa & & & 163 & 163 \\
\hline Hexa & 167 & & & \\
\hline Hexa & 169 & & & \\
\hline Hepta & & & & 170 \\
\hline
\end{tabular}




\begin{tabular}{|l|l|l|c|c|}
\hline \multirow{2}{*}{ Homologs } & \multirow{2}{*}{$\begin{array}{c}\text { TEF } \\
\text { Congeners }\end{array}$} & \multicolumn{3}{|c|}{ Congeners $^{\mathbf{a}}$ Found in Aroclors at 0.9\% or Higher } \\
\cline { 3 - 5 } & & Aroclor- 1248 & Aroclor- 1254 & Aroclor- 1260 \\
\hline Hepta & & & & 171 \\
\hline Hepta & & & & 174 \\
\hline Hepta & & & & 177 \\
\hline Hepta & & & & 179 \\
\hline Hepta & & & & 180 \\
\hline Hepta & & & & 184 \\
\hline Hepta & & & & 187 \\
\hline Hepta & 189 & & & 194 \\
\hline Octa & & & & 196 \\
\hline Octa & & & & 203 \\
\hline Octa & & & & 199 \\
\hline Octa & & & & \\
\hline
\end{tabular}

${ }^{a}$ PCB congeners range from PCB-1 to PCB-209

b $\mathrm{TEF}=$ Toxicity equivalency factor relative to toxicity of 2,3,7,8-TCDD. 
WCH-208

Rev. 0 


\section{DISTRIBUTION}

U.S. Department of Energy

Richland Operations Office

K. D. Bazzell A3-04

B. L. Charboneau A6-33

J. G. Morse A6-38

J. P. Sands A3-04

J. Zeisloft A3-04

Washington Closure Hanford

D. T. Bignell H4-25

M. N. Brosee H4-24

S. W. Clark H4-23

K. R. Fecht H4-21

E. T. Feist H4-22

C. W. Hedel H4-22

R. M. Hermann (10) H4-22

L. C. Hulstrom H4-22

J. A. Lerch H4-22

I. D. Jacques H4-22

W. F. Johnson H4-22

J. M. Queen H4-22

D. D. Teel H4-21

J. E. Thomson H4-22

B. L. Vedder H4-22

R. L. Weiss H4-21

\section{Fluor Hanford}
A. L. Prignano
$\mathrm{H} 8-40$

Pacific Northwest National Laboratory

G. W. Patton

$\mathrm{K} 6-75$

R. G. Riley

$\mathrm{K} 2-21$

Document Control

H4-11

DOE-RL Public Reading Room

$\mathrm{H} 2-53$

Hanford Technical Library

P8-55 
WCH-208

Rev. 0 